\title{
The Influence of Warmer Temperatures Brought on by Climate Change on the Mobility of Arsenic from Lake Sediments
}

\author{
by \\ Brittany C. Astles
}

A thesis submitted to the Faculty of Graduate and Postdoctoral Affairs in partial fulfillment of the requirements for the degree of

Master of Science

in

Geography with Specialization in Data Science

Carleton University

Ottawa, Ontario

(C) 2021

Brittany C. Astles 


\begin{abstract}
Legacy arsenic contamination from past mining operations remains an environmental concern in lakes of Yellowknife (Northwest Territories) due to its post-depositional mobility. Warmer temperatures associated with climate change may impact arsenic diffusion from lake sediments either by direct effect on diffusion rate or indirect effects on microbial metabolism and sediment redox conditions. This thesis assessed the influence of warmer temperatures on arsenic diffusion from contaminated sediment of two lakes using an experimental incubation approach. Yellowknife Bay sediments (with clay, $10 \%$ organic matter, and arsenic $=1700 \mu \mathrm{g} / \mathrm{g}$ ) differed from sediments of Lower Martin Lake (with $\sim 70 \%$ organic matter and arsenic $=822 \mu \mathrm{g} / \mathrm{g}$ ). Duplicate sediment batches from each lake were incubated for four weekly temperature treatments $\left(5^{\circ} \mathrm{C}\right.$ to $20{ }^{\circ} \mathrm{C}$ at $5^{\circ} \mathrm{C}$ intervals) under well-oxygenated conditions and regularly sampled for surface water chemistry. Temperature had no influence on arsenic flux from either sediment type, and other factors must be considered.
\end{abstract}




\section{ACKNOWLEDGMENTS}

This project was funded by the Natural Sciences and Engineering Research Council (NSERC) and the Northwest Territories Cumulative Impact Monitoring Program, through grants provided to Dr. John Chételat. Thank you to Mike Palmer for providing the sediment cores used in this experiment, and providing the necessary data used to calculate the Fick's Law predicted flux. Thank you to Dr. Jesse Vermaire for guidance throughout the writing process. A special thank you to Dr. John Chételat for being an exceptional thesis supervisor, and whose patience saw no bounds through every hurdle Covid-19 threw at us. I was fortunate to have such a well-organized supervisor with high standards who made sure I was on track throughout this whole process.

Thank you to the faculty, staff, and other graduate students of the Geography and Environmental studies department for the academic and emotional support. I would especially like to thank my geography platoon. Despite being cut short by Covid, our time spent together in the office will always be a fond memory.

I would like to thank my friends and family for always supporting me. Mom and Dad, thank you for being great parents and encouraging my interest in environmental sciences. Thank

you for letting me collect many rocks and being my rocks that have always kept me grounded. Thank you, Elliot, for being the worlds best cat. Lastly, I would like to thank my partner Terenzo Giovannitti who has been my anchor and my best friend throughout the entirety of my undergraduate and graduate degrees. I cannot imagine going through this process without having you by my side. 


\section{TABLE OF CONTENTS}

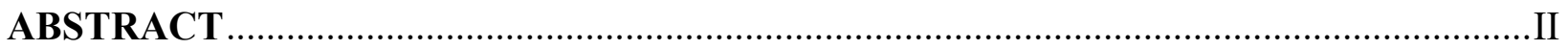

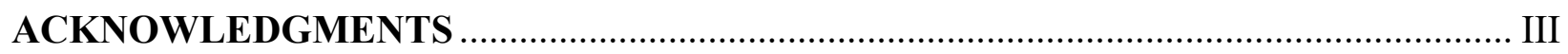

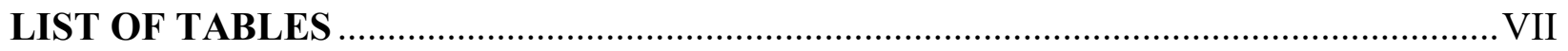

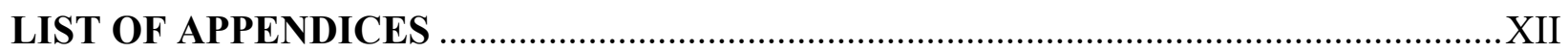

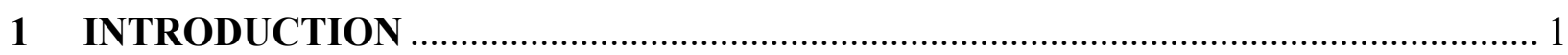

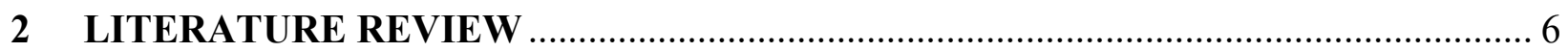

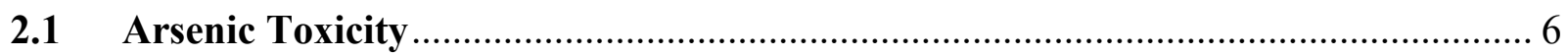

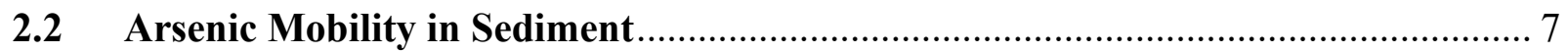

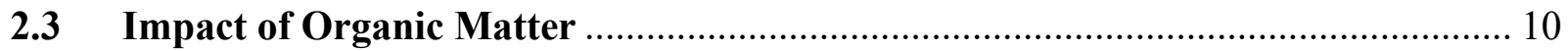

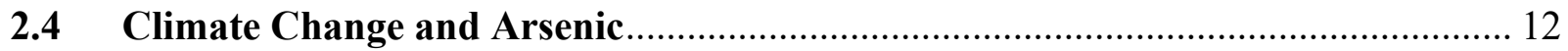

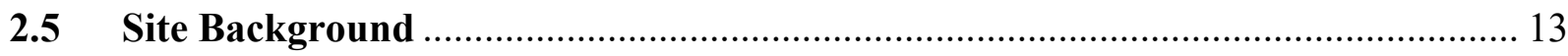

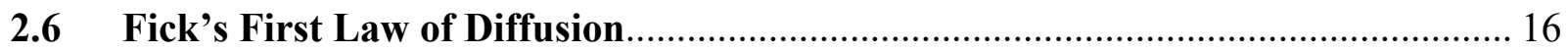

3 WARMER WATER ALONE IS INSUFFICIENT TO INCREASE THE MOBILITY

OF ARSENIC FROM MINING-CONTAMINATED SEDIMENTS IN THE YELLOWKNIFE AREA, NORTHWEST TERRITORIES ………………….................. 19

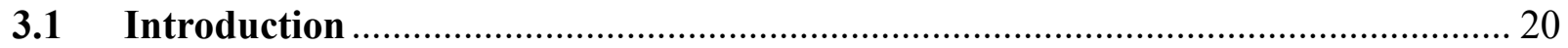

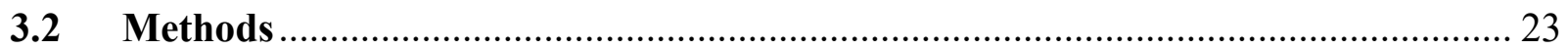

3.2.1 Environmental Background and Study Site ............................................... 23

3.2.2 Sediment and Lake Water Collection ……..................................................... 26

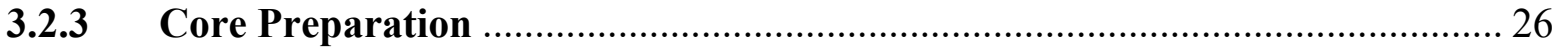




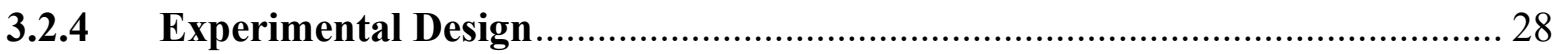

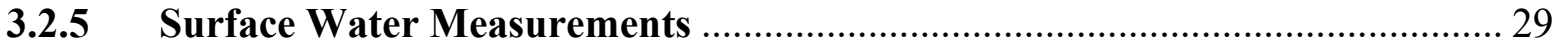

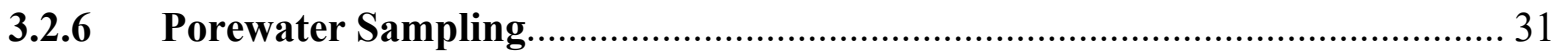

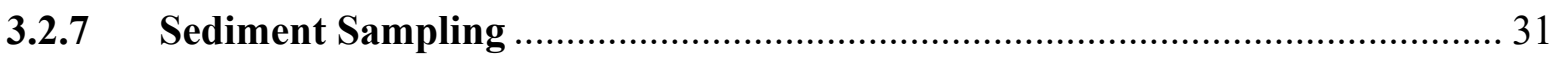

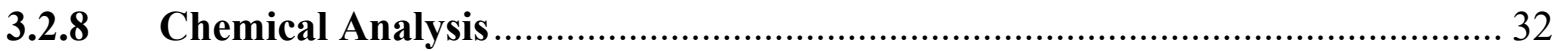

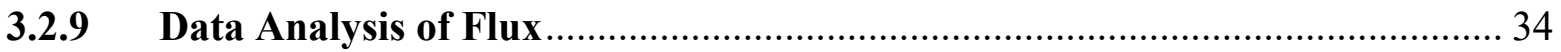

3.2.10 Data Analysis using Fick's First Law................................................ 34

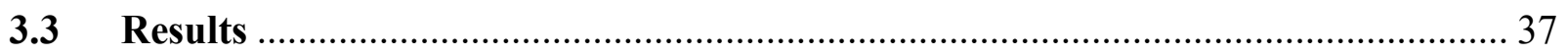

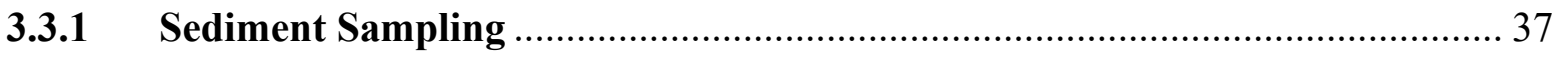

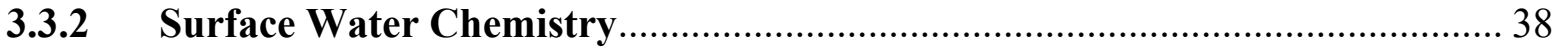

3.3.3 Surface Water Metal(loid) Fluxes .......................................................... 42

3.3.4 Theoretical Estimates of Temperature Influence on Arsenic Flux from Lower

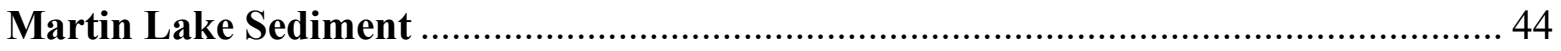

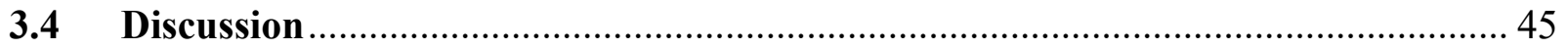

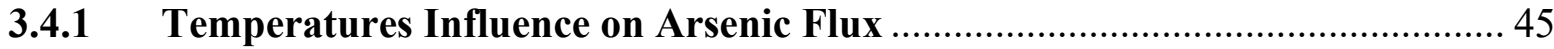

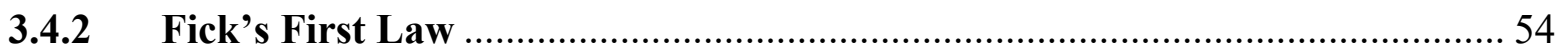

3.4.3 Implications of Climate Change ............................................................ 55

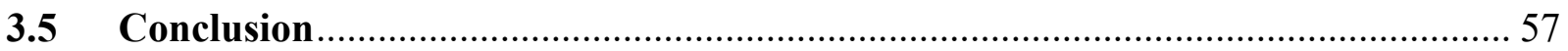

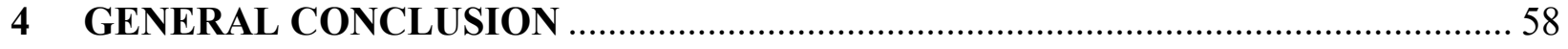

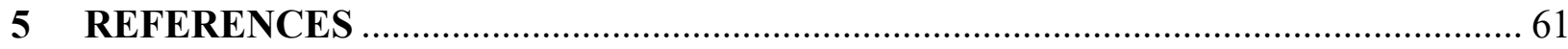


6 APPENDICES.

A. Surface Water, Porewater and Sediment Characteristics ........................................ 77

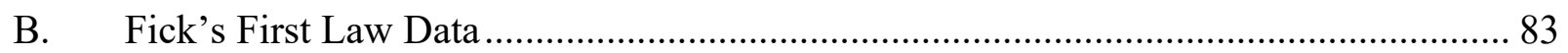

C. $\mathrm{R}$ code for Calculating Predicted Sediment Fluxes of As from Lower Martin Lake..... 84 


\section{LIST OF TABLES}

Table 3.1: Experimental sampling schedule for surface water and porewater collection........... 29

Table 3.2: Chemical characteristics of overlying water during the sediment incubation experiment.

Table 3.3: Metal(loid) flux estimates ( $\mu \mathrm{g} / \mathrm{m}^{2} /$ day) from Yellowknife Bay and Lower Martin Lake sediments, averaged across temperature treatments.

Table 6.1: Surface water sampled at the beginning and end of the experiment was analyzed for a suite of 25 elements by ICP-MS for background water chemistry at Taiga Environmental Laboratory in Yellowknife. Values shaded red were below the method detection limit (MDL). 77

Table 6.2: General water quality measured in the stock surface water added to the cores and the surface waters at the end of the experiment. The chemical analyses were performed at Caduceon Environmental Laboratory in Ottawa. 78

Table 6.3: Surface water of the four sediment cores in the experiment were analyzed by ICP-MS for water chemistry at Taiga Environmental Laboratory in Yellowknife. Values shaded red were below the MDL. 78

Table 6.4: Porewater concentrations of Lower Martin Lake sediment measured weekly during the incubation experiment. Element concentrations were measured by ICP-MS at Taiga Environmental Laboratory in Yellowknife. 81

Table 6.5: Chemical analysis for Yellowknife Bay and Lower Martin Lake sediment used in the incubation experiment. Element concentrations were measured by ICP-MS at Bureau Veritas in Vancouver, BC 82

Table 6.6: Calculated Viscosity Coefficient and Diffusion coefficient at given Ambient

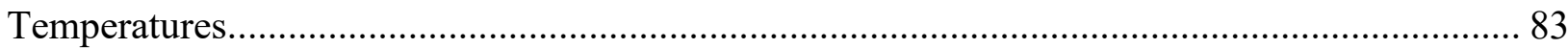


Table 6.7: Measured Particle Density in 2 Lower Martin Lake cores collected by Mike Palmer, used to calculate average particle density used in the Porosity coefficient calculation. Average of both cores calculated to be $0.01 \mathrm{~g} / \mathrm{cm}^{3}$. 83 


\section{LIST OF FIGURES}

Figure 1.1: Approximate locations where the sediment cores were collected from Lower Martin Lake and Yellowknife Bay. Location of the Giant Mine and Con Mine in relation to the capital of the Northwest Territories, Yellowknife. ............................................................................. 5

Figure 2.1: Diagram of the As contamination entering the surrounding environment of Giant Mine and Con Mine. 8

Figure 3.1: Incubated sediment cores from Yellowknife Bay of Great Slave Lake and Lower Martin Lake. Note the opaque plastic bags covering the sediments within each core to prevent algal growth except at the surface of the Lower Martin Lake sediment. Also, note the cap of each core with the wiring and drilled ports for the sensors for continuous measurement of temperature, $\mathrm{pH}$ and redox potential, and piping for an oxygen bubbler. 28

Figure 3.2: Sediment profile of the Yellowknife Bay cores from 1 to $5 \mathrm{~cm}$ depth. A duplicate of sediment of core 3 from $1-1.5 \mathrm{~cm}$ had an average RSD for Mn, Fe, As, and S below $<1 \% \ldots . . .38$

Figure 3.3: Metal(loid) concentration of $\mathrm{As}, \mathrm{Fe}$, and $\mathrm{Mn}$ in overlying surface water, within the Lower Martin Lake and Yellowknife Bay cores, throughout the 30-day experiment. Concentration is measured in $\mu \mathrm{g} / \mathrm{L}$. Each Grey line represents a new temperature treatment. The RSD of As, Fe, and $\mathrm{Mn}$ for all the duplicates were on average less than $8 \%$.

Figure 3.4: The concentration of $\mathrm{SO}_{4}{ }^{2-}, \mathrm{DN}$ and DOC and ORP of overlying surface water within the Lower Martin Lake and Yellowknife Bay cores, throughout the 30-day experiment. Each grey line represents a new temperature treatment. The $\mathrm{RSDs}$ for $\mathrm{SO}_{4}{ }^{2-}, \mathrm{DN}$, and DOC duplicates were $<1 \%$.

Figure 3.5: Metal(loid) fluxes between overlying water and sediment from Lower Martin Lake and Yellowknife Bay incubated at different temperatures. There are two points for each 
temperature treatment as they represent the calculated flux within duplicate lake cores at the

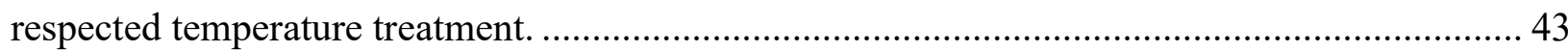

Figure 3.6: Predicted arsenic flux of the Lower Martin Lake cores calculated using Fick's Law, versus the measured As flux in those cores. The flux is measured in $\mu \mathrm{g} / \mathrm{m}^{2} /$ day and temperature is

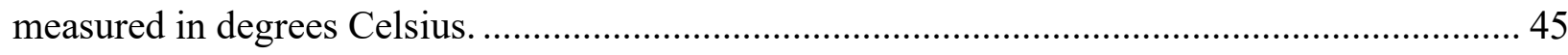




\section{LIST OF EQUATIONS}

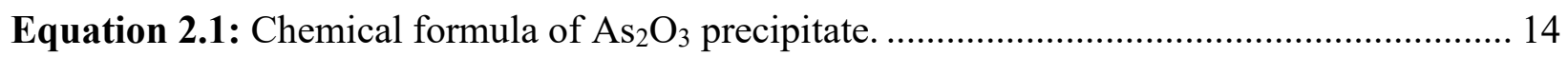

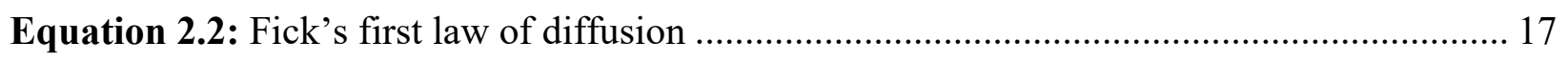

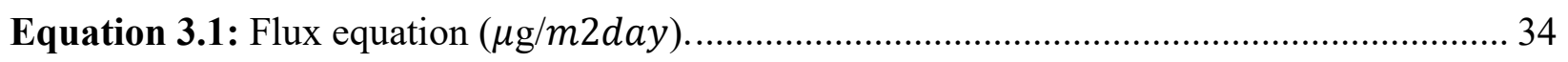

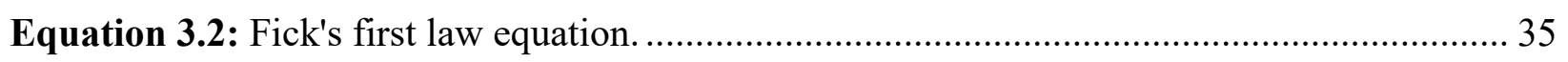

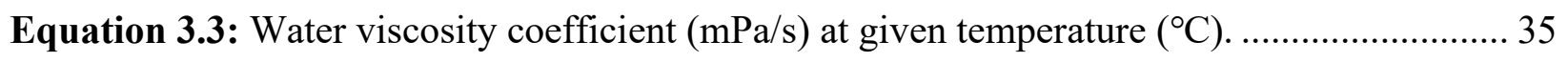

Equation 3.4: Diffusion coefficient equation. ............................................................. 35

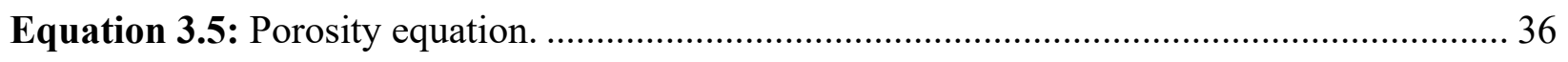

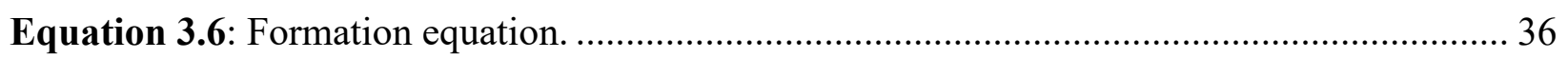

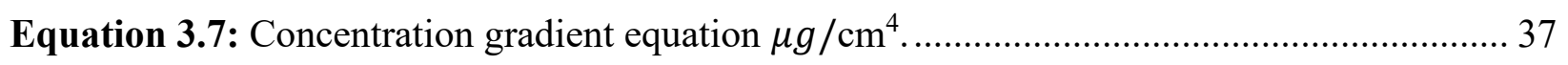




\section{LIST OF APPENDICES}

A. Surface Water, Porewater and Sediment Characteristics 77

Table 6.1: Surface water sampled at the beginning and end of the experiment was analyzed for a suite of 25 elements by ICP-MS for background water chemistry at Taiga Environmental Laboratory in Yellowknife. Values shaded red were below the method detection limit (MDL).

Table 6.3: Surface water of the four sediment cores in the experiment were analyzed by ICPMS for water chemistry at Taiga Environmental Laboratory in Yellowknife. Values shaded red were below the MDL 78

Table 6.4: Porewater concentrations of Lower Martin Lake sediment measured weekly during the incubation experiment. Element concentrations were measured by ICP-MS at Taiga Environmental Laboratory in Yellowknife. 81

Table 6.5: Chemical analysis for Yellowknife Bay and Lower Martin Lake sediment used in the incubation experiment. Element concentrations were measured by ICP-MS at Bureau Veritas in Vancouver, BC 82

B. Fick's First Law Data 83

Table 6.6: Calculated Viscosity Coefficient and Diffusion coefficient at given Ambient Temperatures. 83

Table 6.7: Measured Particle Density in 2 Lower Martin Lake cores collected by Mike Palmer, used to calculate average particle density used in the Porosity coefficient calculation. Average of both cores calculated to be $0.01 \mathrm{~g} / \mathrm{cm}^{3}$. 83

C. R code for Calculating Predicted Sediment Fluxes of As from Lower Martin Lake .... 84 


\section{LIST OF ABREVIATIONS}

As - Arsenic

$\mathbf{A s s}_{2} \mathbf{S}_{3}$ - Arsenic Sulphides

$\mathrm{As}_{2} \mathrm{O}_{3}$ - Arsenic Trioxide

$\operatorname{As}(\mathbf{V})$ - Inorganic Pentavalent Arsenic $\left(\right.$ Arsenate $\left.\left.=\mathrm{AsO}_{4}{ }^{3-}\right)\right)$

As(III) - Inorganic Trivalent Arsenic (Arsenite $\left.=\mathrm{AsO}_{3}{ }^{3-}\right)$

$\mathrm{HCO}_{3}^{-}$- Bicarbonate

$\mathbf{C O}_{2}$ - Carbon Dioxide

DMA - Dimethylarsenic Acid

DN - Dissolved Nitrogen

DOC - Dissolved Organic Carbon

Fe - Iron

$\mathrm{HNO}_{3}$ - Nitric Acid

MDL - Method Detection Limit

Mn - Manganese

MMA - Monomethylarsonic Acid

NDIR - Non-Dispersive Infrared

NWT - Northwest Territories

$\mathbf{O M}$ - Organic Matter

ORP- Oxydation-Reduction Potential

QA/QC - Quality Assurance \& Quality Control

RSD - Relative Standard Deviation

S - Sulphur 
$\mathbf{S}^{2-}$ - Sulphide

$\mathbf{S O}_{2}$ - Sulphure Dioxide

$\mathbf{S O}_{4}{ }^{2-}-$ Sulphate 


\section{INTRODUCTION}

Arsenic (As) is a naturally occurring element within the earth's crust (Sharma \& Sohn, 2009). There are four oxidation states of As, with arsenate $(\mathrm{As}(\mathrm{V}))$ and arsenite (As(III)) being the most common in the environment. Despite As being a natural element, it is commonly released from human activities such as the burning of fossil fuels, mining, and in the application of pesticides (Bissen \& Frimmel, 2003). Organic As is generally safer than inorganic As (Sharma \& Sohn, 2009; $\mathrm{Ng}, 2005$ ), and inorganic As tends to have a higher toxicity and can be dangerous to human health. Inorganic As is toxic and is a known carcinogen (Ng, 2005, Smith et al., 1992), and its toxicity is dependent on its chemical speciation (La Force et al., 2000; Sharma \& Sohn, 2009). Typically, As(III) is the most toxic form of inorganic As species because of its reactivity to sulphyhydryl groups of biomolecules, which impedes the activities of certain enzymes such as glutathione and lipoic acids and proteins (Aposhian \& Aposhian, 2006; Sharm \& Sohn 2006). Also, As(III) can be more mobile because $\mathrm{As}(\mathrm{V})$ forms surface complexes on minerals more readily than $\mathrm{As}(\mathrm{III})$ (Sharma \& Sohn, 2009), and As(V) tends to compete with phosphate for binding locations on solid surfaces such as goethite (Gao \& Mucci, 2001; Sharm \& Sohn 2009) and ferrihydrite (Jain \& Loeppert, 2000; Dixit \& Hering, 2003; Sharm \& Sohn 2009; Hellweger \& Lall 2004; Raab \& al., 2007). The main entry of As into the human body is through water and food consumption (WHO; 2017). The current limit of allowable As in drinking water before it becomes dangerous to the human body is $10 \mu \mathrm{g} / \mathrm{L}$ of inorganic As, and consuming more than $60,000 \mu \mathrm{g} / \mathrm{L}$ can be fatal (Wang \& Mulligan 2002; WHO, 1993). Acute As poisoning symptoms depend on the rate at which the compound can be removed from the body, however in extreme cases that it cannot be removed fast enough, acute As poisoning can lead to gastrointestinal discomfort, vomiting, coma, and in extreme cases death (Wang \& Mulligan, 2005; WHO, 1993). Chronic As poisoning can result in 
anemia, dermal lesions such as hyperpigmentation and hypopigmentation, leucopenia, peripheral neuropathy, skin cancer, bladder and lung cancers, and peripheral vascular disease (Wang \& Mulligan, 2005; WHO 1993; WHO 2017). In fish, As can reduce their growth, hinder their feeding, cause tissue lesions, and decrease egg production (Boyle et al., 2008; Pedlar et al., 2002; Erickson et al., 2010; Woodward et al., 1995). Due to its toxicity and environmental impact, it is important to understand how As can move within aquatic environments.

There is a lack of research on how environmental As can be influenced by temperature in freshwater lakes (Palmer et al., 2019). This thesis is part of a larger ongoing research program that began with Environment and Climate Change Canada investigating the legacy mining contamination in the Yellowknife area of Northwest Territories (NWT). Lakes within the Yellowknife area are contaminated with As from historical mining activities during the $20^{\text {th }}$ Century. The two most prominent mines in the Yellowknife area were the Giant Mine and Con Mine (Moir et al., 2006). Both locations were mining and roasting ore for gold, and Giant Mine generated about 7 million ounces of gold throughout its production from 1948-2004, resulting in it being one of the most productive gold mines in Canadian history (Moir et al., 2006). The gold generating process required the roasting of ore, which created a substantial amount of solid waste and aerial emissions (Palmer et al., 2016). These aerial emissions released precipitated arsenic trioxide (As2O3) into the surrounding environment of the mines (Moir, et al., 2016). Inorganic As was one of the primary contaminants released by gold mines in the Yellowknife area and is still found at elevated concentrations in the receiving environment (Thienpont et al. 2016, Chételat et al. 2018). 
In the sediments of Yellowknife Bay, the tailings of Giant Mine and the soil surrounding the Giant Mine property contained a mixture of $\mathrm{As}(\mathrm{III})$ and $\mathrm{As}(\mathrm{V})$-bearing maghemite and hematite which contained approximately $7 \mathrm{wt} \%$ of As (Andrade et al., 2010; Bromstad et al., 2017; Van Den Berghe et al., 2017; Walker et al., 2005). In a $30 \mathrm{~km}$ radius around the historical mining site the As concentration in the near-surface sediments of the surrounding lakes ranged from $5 \mu \mathrm{g} / \mathrm{g}$ to over $10,000 \mu \mathrm{g} / \mathrm{g}$ (Galloway et al., 2017). The As concentration of the lake sediments are dependent on the distance and direction from the mine site, and typically lakes that are within 11 $\mathrm{km}$ from the mine had the highest As concentration in their sediments (Galloway et al., 2017). Within the north end of Yellowknife Bay, closest to the Giant Mine site, the surface water As concentration is $\sim 3 \mu \mathrm{g} / \mathrm{L}$, whereas the main body of Great Slave Lake is $<1 \mu \mathrm{g} / \mathrm{L}$ (Chételat et al., 2017, 2019). In Lower Martin Lake, the mean As surface water concentration was measured at 60 $\mu \mathrm{g} / \mathrm{L}$ (Palmer et al., 2019). The concentration of As tends to be greatest at the sediment-water interface, suggesting the mobility of As in the lake sediments, however the evidence also suggests that As is bound to the sediments at the surface water interface (Palmer et al., 2019; Van Den Berghe et al., 2017). Inorganic As can naturally diffuse through lake sediments and has been shown to do so in Great Slave Lake sediments (Andrade et al., 2010; Chételat et al. 2018; Galloway et al., 2017; Palmer et al., 2019). The concentrations of As in Great Slave Lake's sediments have been studied over the past 30 years (Wagemann et al., 1978).

Environmental conditions are changing and will change more with climate warming and these environmental changes could influence the stability of legacy As contamination in the Yellowknife area. A study by Barrett et al. (2019) identified that the key control of As mobilization is organic carbon because microbial decomposition of organic carbon consumes oxygen and other electron 
acceptors, which turns the environment into an iron (Fe)-reducing state and results in the mobilization of As from the sediment particles at the sorption sites (Barrett et al., 2019). Since microbial activity is influenced by temperature (Ratkowsky et al., 1982), it is believed that temperature can impact the mobility of sediment As, which has been shown in laboratory studies on terrestrial soils and lake sediment experiments (Weber et al., 2010; Barrett et al., 2019). Therefore, the As flux from sediment within the lakes could possibly be influenced by increasing temperature. This project aims to generate new information on the influence of temperature on As diffusion within contaminated sediment, and to investigate whether sediment organic content influences the diffusion flux of As. Little information is available on the temperature influence of As diffusion in freshwater sediment. By understanding what environmental conditions impact the diffusion of As from sediment in freshwater lakes, we can predict how As diffusion can possibly be influenced by the environmental changes brought on by climate change. With climate change increasing the temperature within the subarctic, the fate of the legacy mine contaminants is of high interest to researchers and those living within the surrounding area.

This thesis assessed the influence of warmer temperatures on As diffusion from contaminated sediment with different composition using an experimental 30-day incubation approach. This study compared As diffusion rates from sediment at two sites with different geochemical characteristics. I hypothesized that As flux would increase with warmer temperature treatments and I also predicted that the As flux will be highest in higher organic matter (OM) rich sediments. Two of the sediment cores were retrieved from within Yellowknife Bay of Great Slave Lake and the other two were collected from Lower Martin Lake (Figure 1.1). The objective of this research was to determine if temperature alone would influence the As flux from mine contaminated 
sediments into the overlying water. With the increasing rise in temperature brought on by climate change it is important to understand how temperature can influence changes in contaminant exposure within lake sediments with different geochemical composition.

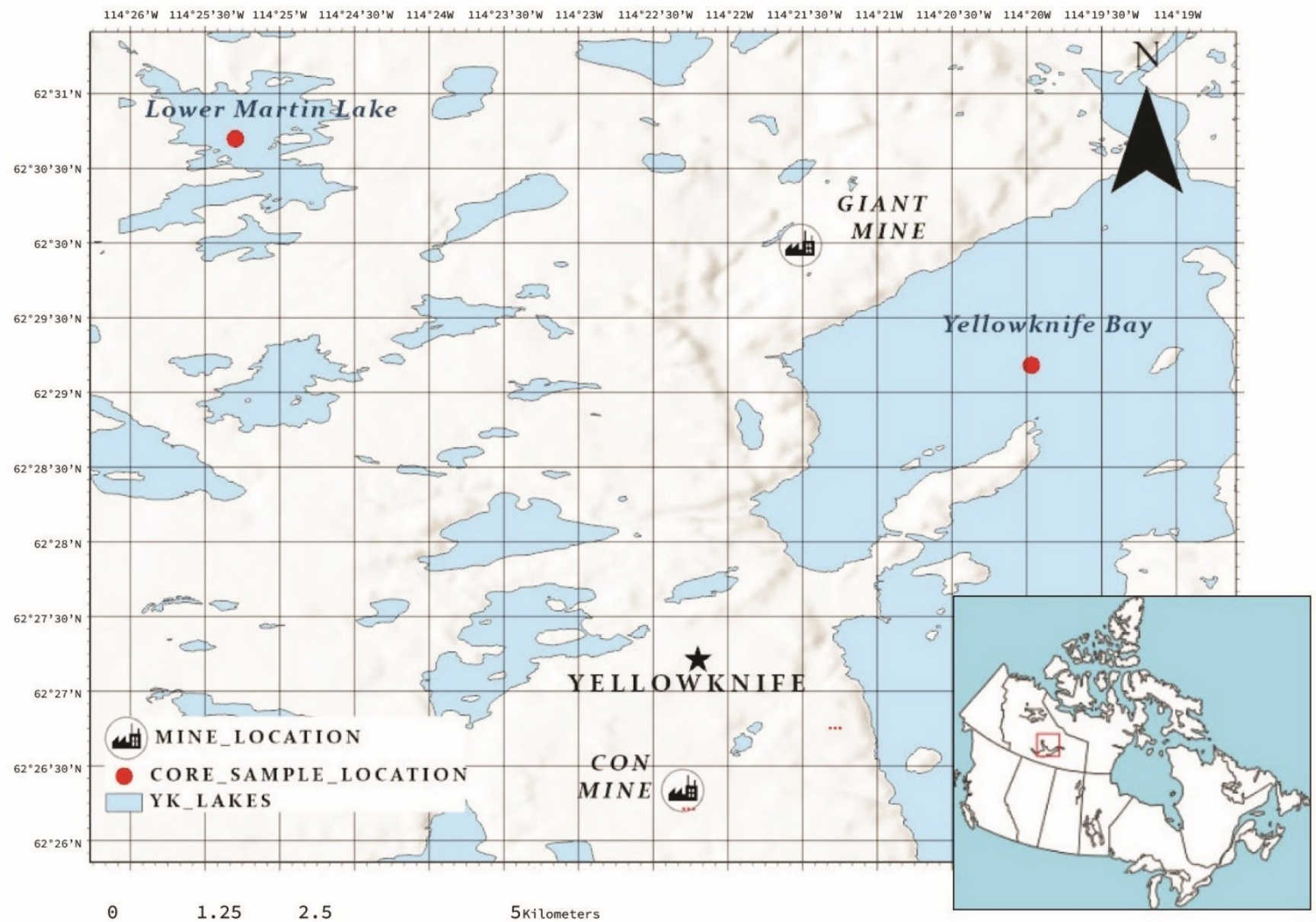

Figure 1.1: Approximate locations where the sediment cores were collected from Lower Martin Lake and Yellowknife Bay. Location of the Giant Mine and Con Mine in relation to the capital of the Northwest Territories, Yellowknife. 


\section{LITERATURE REVIEW}

\subsection{Arsenic Toxicity}

Arsenic can be found in four different oxidation states, however pentavalent arsenate (As(V)), and trivalent arsenite $(\mathrm{As}(\mathrm{III}))$ are the most common forms to be found within freshwater environments (Rahman \& Hasegawa, 2012; Sharma \& Sohn, 2009). Organic forms of As such as dimethylarsinic acid (DMA) and monomethylarsonic acid (MMA) can also be found in freshwater environments, although at lower concentrations (Rahman \& Hasegawa, 2012). According to numerous studies, the physicochemical properties of the freshwater environment are what determines the speciation of As within the environment because the As speciation is dependent on the redox conditions of the water, and thus determines As toxicity to the local environment's organisms (Sharma and Sohn, 2009).

There are different mineral forms of As found within lake sediments in the surrounding Yellowknife area such as $\mathrm{As}_{2} \mathrm{O}_{3}$, arsenopyrite, arsenic sulphides $\left(\mathrm{As}_{2} \mathrm{~S}_{3}\right)$, and dissolved organic and inorganic As species in the water column (Van Den Berghe et al., 2017). The different type of dissolved As species determines their diffusion properties and toxicity. The speciation of As is $\mathrm{pH}$ dependent, as pH impacts the solubility of anions of iron (Fe)-hydroxides (Masscheleyn et al., 1990). These anions dictate the bioavailability and toxicity of As in aquatic systems (Masscheleyn et al., 1990).

The species of As and their mode of biochemical action is what determines the toxicity of the As to organisms (Rahman \& Hassler, 2014). Inorganic As forms are typically more toxic than organic As, however some organoarsenicals, trivalent methylarsenicals have been reported to be 
more toxic than inorganic As (Rahman \& Hasegawa, 2012). Arsenite is toxic as it impairs the function of proteins and impedes enzyme activity (Rahman \& Hasegawa, 2012; Sharm \& Sohn, 2006; Aposhian \& Aposhian 2006), and As(V) tends to inhibit oxidative phosphorylation, which is when a phosphoryl group is chemically added to an organic molecule (Orelmand \& Stolz, 2003). The toxicity of DMA and MMA is less understood, and there is a lack of research on their impact in freshwater environments (Orelmand \& Stolz, 2003).

Microorganisms such as phytoplankton, are known to have a detoxification mechanism as they are capable of bio-transforming toxic species of As into less toxic species such as organic As (Levy et al., 2005; Oremland \& Stolz, 2003). However, the biological transformations of inorganic As into organoasenicals can create a by-product of MMA(V) and DMA(V). Arsenite is easier for microorganisms to excrete than $\mathrm{As}(\mathrm{V})$, therefore the reduction of $\mathrm{As}(\mathrm{V})$ to $\mathrm{As}(\mathrm{III})$ has been considered a detoxification mechanism, and is one of the reasons trivalent forms of organoasenicals are less common than the pentavalent forms in fresh waters (Oremland \& Stolz, 2003).

\subsection{Arsenic Mobility in Sediment}

Arsenic was deposited into the sediments of Yellowknife Bay and Lower Martin Lake via mining activity at Giant Mine and Con Mine. Through the ore roasting process As-bearing Fe oxides and sulphur dioxide $\left(\mathrm{SO}_{2}\right)$ were emitted from smokestacks into the atmosphere. Once in the atmosphere, the As vapor precipitated as $\mathrm{As}_{2} \mathrm{O}_{3}$ and was deposited into the surrounding environment (Palmer et al., 2015). Arsenic also entered Yellowknife Bay by mine wastewater effluent that was directly discharged into the bay (Palmer et al., 2019). Arsenic continues to enter 
the lake from leaching of soils in the water catchment. Once As mine wastes enter the lake, they settle out to the bottom of the lake in the sediments. Over time the sediments accumulate, partially burying the As contamination. Some of the mineral As undergoes dissolution, resulting in dissolved As in porewater that is mobile and can diffuse upwards through the sediment to the surface, and re-enter the water column. The process of As contamination entering the environment in the Yellowknife area is illustrated in Figure 2.1. The speciation and diffusion of porewater As into the overlying water is dependent on the dissolved oxygen and redox conditions within the sediments. Arsenite is dominant in reducing conditions such as the low oxygenated bottom waters and porewater of sediment, while $\mathrm{As}(\mathrm{V})$ is found in well oxygenated environments (Hughes, 2002;

Bowell et al., 2014).

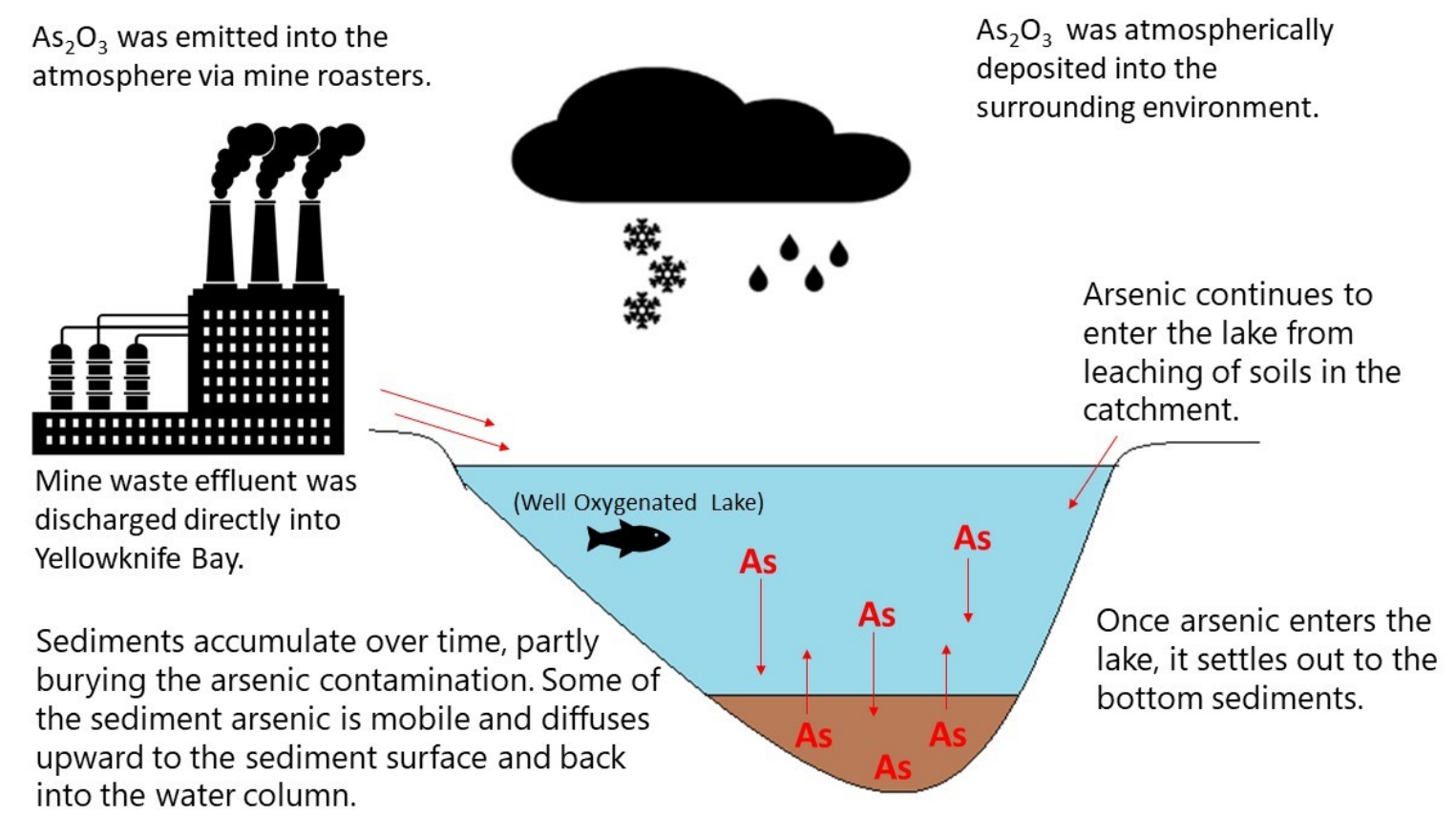

Figure 2.1: Diagram of the As contamination entering the surrounding environment of Giant Mine and Con Mine. 
The increased mobility of As in reducing environments is caused by the formation of As(III) species interacting with the microbial metabolism of organic carbon (Smedley \& Kinniburgh, 2002). Arsenate is reduced to As(III) during microbial respiration of bacteria, algae and archaea with sediments, as $\mathrm{As}(\mathrm{V})$ acts as an electron acceptor during microbial respiration which reduces to As(III) (Campbell \& Nordstrom, 2014; Dixit \& Hering, 2003; Lloyd \& Oremland, 2006; Oremland \& Stolz, 2003; Stachowicz et al., 2008; Stolz \& Oremland, 1999). Also, As host phases such as Fe(III) oxides that undergo microbially mediated reductive dissolution can cause a release of As from the sediments into solution (Burton et al., 2008; Fendorf, Nico, et al., 2010; Hockmann, Lenz et al., 2014; Kocar \& Fendorf, 2009; Kocar et al., 2006). Aqueous As(III) and As(V) -species are strongly associated to Fe(III) minerals (Johnston et al., 2020).

There are many processes that can control the mobility of As from porewater into overlying water (Weber et al., 2010). One such process is microbial reduction of $\mathrm{As}(\mathrm{V})$. If this process occurs in neutral $\mathrm{pH}$ to acidic condition, $\mathrm{As}(\mathrm{III})$ will not strongly sorb to $\mathrm{Fe}(\mathrm{III})$ and aluminum oxides and oxyhydroxides as $\mathrm{As}(\mathrm{V})$ does, and this allows $\mathrm{As}(\mathrm{III})$ to be more readily released into the overlying water (Roberts et al., 2004; Stachowicz, 2008; Dixit \& Hering, 2003). The second possible process is that $\mathrm{Fe}(\mathrm{III})$ (hydr)oxides are poorly crystalline, the Fe(III) reducing bacteria will begin to dissolve the Fe(III) (hydr)oxides, which reduces the number of sorption sites, and frees the sorbed As on the Fe(III) (hydr)oxides into the surrounding water (Tufano et al., 2008). The third process is that an increasing concentration of competing ions such as bicarbonate $\left(\mathrm{HCO}_{3}^{-}\right)$, phosphate, and dissolved organic carbon (DOC) will promote the release of As from $\mathrm{Fe}(\mathrm{III})$ (hydr)oxides (Stachowics et al., 2008; Appelo et al., 2002; Bauer \& Blodau, 2006). In reducing conditions, 
minerals such as magnetite, green rust and sulphide $\left(\mathrm{S}^{2-}\right)$ minerals such as $\mathrm{As}_{2} \mathrm{~S}_{3}$ can form, which becomes a possible sorbent phase for As (Ona-Nguema et al., 2009; Coker et al., 2006; Wang et al., 2008; Wolthers et al., 2005). This then impedes As from entering the porewater and prevents it from diffusing into the surrounding water column (Tufano et al., 2008; Kocar et al., 2006).

\subsection{Impact of Organic Matter}

Organic matter is believed to impact As biogeochemistry, due to OM being highly reactive with metal(loid)s, which can alter the mobility of As (Redman et al., 2002). Humic and fulvic acids of OM have been shown to impede arsenic adsorption under certain circumstances such as at high concentrations of fulvic acid which reduce As adsorption in environment of low $\mathrm{pH}$. Water $\mathrm{pH}$ determines the charge of solid surfaces and the As speciation within the solution, further impacting the sorption behaviour of As (Xu et al., 1991; Xu et al., 1988; Thanabulasingam \& Pickering, 1986), and OM can increase the mobility of As in soil (Jackson \& Miller, 1999). However, it is not fully understood how this process works (Redman et al., 2002). On hematite surfaces OM will displace the sorbe $\mathrm{As}(\mathrm{V})$ and $\mathrm{As}(\mathrm{III})$ from the hematite surface, allowing for As to be displaced and mobilised (Redman et al., 2002). This creates a competition for sorption sites between OM and As and is considered as a potential pathway of As mobilisation (Redman et al., 2002). In an experiment conducted by Redman et al. (2002), in the presence of OM, As(III) tended to desorb or could not properly sorb to hematite surfaces compared to As(V), explaining why As(III) tends to have a greater mobility than $\mathrm{As}(\mathrm{V})$ in natural environments. Previous experiments conducted by Kalbitz \& Wennrich (1998) have shown that As concentration in contaminated wetland soil was positively correlated with the concentration of dissolved OM. Their study also suggested that soil characteristics such as DOC concentration in soil solution should be monitored and is as 
important to monitor as soil potential for adsorption to clay, oxides, cation exchange capacity and soil $\mathrm{pH}$, in assessing the potential mobilization of As (Kalbitz \& Wennrich, 1998).

For these reasons, I will be studying two lakes with sediment of different OM content, to account for the potential influence of OM on As diffusion and bioavailability (Redman et al., 2002). The interaction of $\mathrm{OM}$ and As is heavily $\mathrm{pH}$ dependent, because of the competition for adsorption sites, the presence of large amounts of dissolved OM will encourage the mobilization of As (Wang \& Mulligan, 2006).

In lakes with OM rich sediments, it has been reported that heterotrophic microbial activity influences the precipitation of As as a S-mineral (realgar) (Van Den Berghe, et al., 2017). Arsenicbearing $\mathrm{S}^{2-}$ will remain stable if the lake sediments are in a reduced state (Van Den Berghe, et al., 2017). A study by Galloway et al., (2018) reported that labile OM might act as a substrate for microbial growth, which slows down with the precipitation of $\mathrm{As}_{2} \mathrm{~S}_{3}$, in lakes that were impacted by Giant Mine. This is because OM influences microbial activity within the sediments by promoting microbial growth (Campbell \& Nordstrom, 2014; Galloway et al., 2018; Mladenov et al., 2010), which in turn influences the porewater redox potential gradient. Organic matter acts as an electron shuttle between the Fe and micro-organisms, promoting the microbial community to reduce the Fe and mobilize sorbed As (Galloway et al., 2018; Schwarzenbach et al., 1990; Lovely et al., 1996; Mladenov et al., 2010). Organic matter can cover the surface of sediment particles, creating a large surface area of organic substrates, to which metal(loid)s can bind (Sanei et al., 2005). 
Lake and wetland sediments may act as a sink or source for As (La Force et al., 2000; Gurung et al., 2005; MacDonald et al., 2005; Du Laing et al., 2009). The interactions between As and particulate $\mathrm{OM}$ are controlled by $\mathrm{pH}$ and redox conditions within the system (Smedley \& Kinniburgh, 2002; Du Laing et al., 2009). In turn, the redox conditions within lacustrine environments are controlled by basin morphometry, temperature, OM production and decomposition, and microbial-mediated redox processes within the lake (or wetland) sediments (Toevs et al., 2006). Climate change is impacting the biogeochemical environment in northern latitudes by altering the hydrology of lakes and increasing the length of the ice-free season (MacDonald et al., 2005; Spence et al., 2015). These changes taking place in lakes can cause an increase in biological productivity and OM transport to aquatic environment (Hejzlar et al., 2003; Mann et al., 2013). This may change the stability and mobility of metal(loids) (Hejzlar et al., 2003; Mann et al., 2013).

\subsection{Climate Change and Arsenic}

Climate change has been shown to impact lake water quality by altering precipitation, temperature, radiation, wind speed and direction (Williamson et al., 2009b). Alteration in precipitation, such as with frequency and intensity, impacts surface water runoff and increases contaminant transport to the lakes (Prowse et al., 2006; Horn et al., 2015). Climate change may also increase water temperature, which in turn could lengthen the lake's stratification period, increases the depth of the thermocline, and decrease convective mixing within the lake (Kraemer et al., 2015, Ma et al., 2015). In the case of Yellowknife Bay, warmer temperatures would increase the period of time the bay is stratified and possibly also the stability of the stratification because of a larger temperature gradient (Palmer et al., 2019). These changes to lake water temperature and stratification may also 
enhance the lake's primary productivity (O'Beirne et al., 2017). For this reason, it is important to understand if temperature alone will influence the As flux, before considering the effect an increase in aquatic productivity will have on the As flux.

\subsection{Site Background}

Giant Mine was one of the largest gold mines in the Northwest Territories and produced about 7 million ounces of gold during its operations from 1948 to 2004 (Government of Canada, 2018; Moir et al., 2006), and it was one of the longest continuous running gold mines in Canadian history (Government of Canada, 2018). Over its course of production, Giant Mine was owned by different companies. From 1948 to 1986 it was owned by The Giant Yellowknife Mines, Ltd., then from 1986 to 1990 it was owned by Pamour Inc., and from 1990 it was owned by Royal Oak Mines Inc. until it went into receivership in 1999 and was transferred to the Government of Canada. After the transfer, Giant Mine did not process their ore, but sold assets of Giant Mine to Miramar Giant Mine Ltd., the owner of Con Mine at the time. Though Giant Mine stopped roasting ore in 1999, the mine was still in operation and continued to mine ore until 2004. The ore was trucked to Con Mine for processing (Royle \& Hockley, 2007). Con Mine operated from 1938 to 2003 and was the first gold mine to be developed in the Northwest Territories. Con Mine roasted ore from 1938 to 1970 and Giant Mine roasted ore from 1948 to 1999 and was one of the main sources of As contamination within the area (Schuh et al., 2017). To retrieve the gold from the ore concentrate, the ore had to be roasted so that gold would be susceptible to leaching by cyanide. When the ore concentrate was roasted, it created $\mathrm{SO}_{2}$ emission and an As rich vapour (Bromstad et al., 2017). When the gaseous As cooled it precipitated into $\mathrm{As}_{2} \mathrm{O}_{3}$ (Equation 2.1). The $\mathrm{As}_{2} \mathrm{O}_{3}$ precipitate fell back to the ground, entering the environment in and around the mines. 
Equation 2.1: Chemical formula of $\mathrm{As}_{2} \mathrm{O}_{3}$ precipitate.

$$
2 \mathrm{FeAsS}+5 \mathrm{O}_{2} \rightarrow \mathrm{Fe}_{2} \mathrm{O}_{3}+\mathrm{As}_{2} \mathrm{O}_{3}+2 \mathrm{SO}_{2}
$$

Giant Mine released tailings into Yellowknife Bay on the north shore of the lake from 1948 to 1951 (Moir et al., 2006). Giant Mine's untreated tailings were also discharged directly into Yellowknife Bay via Baker Creek from 1948 to 1951 (Moir et al., 2006). The mine also released untreated effluent via Baker Creek until around 1980, when a water treatment plant was built (Moir et al., 2006). However, the treated effluent was still high in As concentration and continued to be discharged into Yellowknife Bay from Baker Creek for the remainder of the mine operations (Moir et al., 2006).

The Giant Mine gold processing was environmentally harmful and lead to the death of residents and animals in the Yellowknife area (Western, 2021). It's believed many members of the Yellowknives Dene (Weledeh) community fell ill since their main water sources was collected from nearby lakes and snow (Sandlos \& Keeling 2012), and direct consumption of contaminated water or food is the primary pathway for As to enter the body (WHO; 2017). Despite the uncertainty in the amount of acute As poisoning cases, it was reported that several livestock became ill and there was one confirmed case of a child dying from As poisoning (Western, 2021).

Over time the mine began placing mitigation barriers to decrease the level of As contaminants from entering the environment. It has been estimated that more than 20,000 tons of $\mathrm{As}_{2} \mathrm{O}_{3}$ has been released into the surrounding environment via aerial emission throughout Giant Mine's and Con Mines ore roasting operation (Sandlos \& Keeling 2012; Wrye, 2008; Jameison, 
2014). This estimate does not include effluent or tailings contamination. This deposited $\mathrm{As}_{2} \mathrm{O}_{3}$ is still found within the surrounding lake sediments and remains a legacy contamination issue despite the end of the gold production in 2005. The buried legacy As can undergo dissolution, diffuse through the lake sediments and enter the overlying water column by a series of biogeochemical reactions.

For this thesis, two sites in the receiving environment of As contaminants were examined, Yellowknife Bay and Lower Martin Lake. Yellowknife bay is the main waterbody that is downstream and runs adjacent to the Giant Mine. Giant Mine discharged its effluent waste directly into Yellowknife Bay via Baker Creek (Moir et al., 2006). Lower Martin Lake is close to the mine and received aerial emissions from the mine (Van Den Berghe et al., 2018). The lake is also the main water source for Baker Creek which drains through the mine property into Yellowknife Bay.

After the closure of Giant Mine, the As concentration within the surface water was approximately $<5 \mu \mathrm{g} / \mathrm{L}$ in the northern end of Yellowknife Bay near Giant Mine (Chételat et al., 2018). With a background concentration of $<1 \mu \mathrm{g} / \mathrm{L}$, the As concentration in Yellowknife Bay surface water is relatively low but still higher than the arsenic background concentration of the area (Chételat et al., 2017). The As concentration within the sediments declined exponentially, with an increase distance south of Giant Mine in Yellowknife Bay and is the greatest within $5 \mathrm{~km}$ distance from the mine (Chételat et al., 2017). The lowest As concentration is found in the sediments $25-30 \mathrm{~km}$ south from the mine, within the main body of Great Slave Lake (Chételat et al., 2017). Despite an exponential decrease, contamination of the sediments has been found in the main body of Great Slave Lake up to 25 to $30 \mathrm{~km}$ south of Giant Mine (Chételat et al., 2017). 
Great Slave Lake is situated south of the Yellowknife Greenstone Belt; therefore, it is underlined by granitoid bedrock, and not by the Archaean metavolcanics rock founded at the Con and Giant Mine mineral deposits (Moir et al., 2006). The small lakes of the area, such as Lower Martin Lake, are leftover from the last 10,000 years of the Glacial Lake McConnel and the ancestral lake of Great Slave Lake (Wolfe et al., 2014; Wolfe et al., 2015). The area is underlain by granitic and basaltic bedrock and has a low As concentration estimated at $\sim 2 \mu \mathrm{g} / \mathrm{g}$ within the bedrock (Boyle, 1960; Hubbard et al., 2006). The As concentration found within the discontinuous glacial-lacustrine till that overlay the granitic bedrocks have been measured from 8-50 $\mu \mathrm{g} / \mathrm{g}$ (Kerr, 2006).

The Water Survey of Canada has been monitoring the discharge from Lower Martin Lake since 1983 (Station number 07SB013) (Palmer et al, 2019). Lower Martin Lake has a general outflow throughout the year, with a daily average discharge of less then $0.2 \mathrm{~m}^{3} / \mathrm{s}$ between the end of September and the beginning of May (Palmer et al, 2019). Lower Martin Lake drains into Baker Creek which in turns discharges into Yellowknife Bay. This hydrological connection is another source of As being released from Lower Martin Lake sediments into its catchment and functions as a source of As for Yellowknife Bay. At the sediment-water interface sediment cores have shown a dissolved As concentration plateau, possibly caused by sediment bioturbation, or the yearly freezing and thawing of the sediments (Van Den Berghe et al., 2018).

\subsection{Fick's First Law of Diffusion}

The flux of metal(loid)s and nutrients is the one-dimensional flow between sediment and overlying water. There are multiple ways to estimate the flux of As from sediments (Barrett et al., 2019; 
Johnston et al., 2020; Li et al., 2020). One method is to take regular water samples directly from the lake at various times and measure the change in the flux directly in the lake. However, estimates generated from this approach can be confounded by other inputs and outputs of As to and from the lake. A laboratory method to estimate the flux can be carried out under controlled conditions by measuring the flux using a diffusion chamber or experimental incubation, to estimate how As could mobilize in a natural environment. This is done by regularly sampling surface water in incubated sediments cores and measuring the As concentration and calculating how the mass of As has changed over time. This method has been used in various studies such as Palmer et al. (2019) and Johnston et al. (2020). Rarely, the diffusion chamber or experimental incubation method is coupled with the theoretical estimate of flux calculated with Fick's First Law of Diffusion, so that the physical measured flux can be compared to the theoretical estimate. Studies on the transport properties of nutrients and heavy metals often rely on Fick's First Law of Diffusion to derive their flux (Equation 2.2). Fick's First Law of Diffusion is comparable to Ohm's Law for electrical conduction and to the Fourier theory of heat conduction (Tyrrell, 1964).

Equation 2.2: Fick's first law of diffusion

$$
J z=-\left[\frac{D^{\circ}}{F} \times \varphi \times \frac{d c}{d z}\right]
$$

These parameters are all used in Fick's First Law to estimate the diffusion of elements through the sediment porewater into the overlying water column represented by the coefficient $\mathrm{Jz}$, which is measured in the mass per unit area per unit time such as $\left(\mu \mathrm{g} / \mathrm{m}^{2} /\right.$ day) (Lyons, 2010). The diffusion coefficient $\left(D^{\circ}\right)$ is the coefficient of diffusion of the porewater which is measured in $\mathrm{cm}^{2} / \mathrm{s}$, porosity $(\varphi)$ of the lakes sediments is the void space between particles and is a unitless coefficient 
calculated by dividing the sediment bulk density by the average particle density and subtracting the ratio from 1. A high porosity would have a value closer to 1 , and a low porosity would be closer to 0 . The formation resistivity factor $(\mathrm{F})$ is the ratio of resistivity of the porous sediment and is the third root of the porosity, which is also unitless, the concentration gradient ( $\mathrm{dc} / \mathrm{dz}$ ) is calculated using the upper and lower concentration of the element of interest and the depth at which they were measured, typically measured at the surface water interface and within the sediment pores with units of $\mu \mathrm{g} / \mathrm{cm}^{3} / \mathrm{cm}$.

To effectively use Fick's First Law for As diffusion it requires a series of assumptions. The first assumption is that viscosity and the ion coupling charges are negligible. It is assumed that within the sediment-water interface there is no solid phase consumption of dissolved As. The As concentration gradients are linear with little to no physical and biological interference. It also assumes that the change in concentration of the dissolved As is uniform through the surface water interface. Also, that the sediment material is homogenous through out the lake's sediments. These assumptions are associated with the use of Fick's First Law, however the predicted diffusion flux calculated tends to produce conservatively low values (Azcue et al., 1994; Lavery et al., 2001). For this study, the assumptions were not completely met. The sediments of Yellowknife Bay were a slurry mix that can be considered homogenous, however the sediments of Lower Martin Lake were a heterogenous composition rich in $\mathrm{OM}$, so it does not meet the assumption of little to no physical and biological interference and that the sediments are homogenous. However, despite these assumptions not being fully met, the use of Fick's First Law is still an appropriate method to calculate an estimate of the predicted As flux of both lake sediments. 


\title{
3 WARMER WATER ALONE IS INSUFFICIENT TO INCREASE THE MOBILITY OF ARSENIC FROM MINING- CONTAMINATED SEDIMENTS IN THE YELLOWKNIFE AREA, NORTHWEST TERRITORIES
}

\author{
Brittany C. Astles ${ }^{1}$, John Chételat ${ }^{2}$, Jesse C. Vermaire ${ }^{1}$, Mike Palmer ${ }^{3}$ \\ ${ }^{1}$ Geography and Environmental Studies, Carleton University, Ottawa, Canada \\ ${ }^{2}$ Environment and Climate Change Canada, National Wildlife Research Centre, Ottawa, Canada \\ ${ }^{3}$ North Slave Research Centre, Aurora Research Institute, Yellowknife, Canada
}

This chapter will be submitted as a manuscript to a journal (to be determined)

Author contributions:

$\mathrm{JC}$ and MP designed the study;

JC and MP collected the sediment cores and lake water;

$\mathrm{BCA}$ conducted the experiment and data analysis;

BCA wrote the manuscript;

$\mathrm{JC}$ and JCV provided manuscript revisions. 


\subsection{Introduction}

Arsenic is a naturally occurring metalloid however its non-organic form is considered toxic and is a known carcinogen to humans and other organisms (Bissen \& Frimmel, 2003). Arsenic is mobilized within the environment through anthropogenic activities such as ore processing, disposal of mine waste, fossil-fuel combustion, and pesticide application (Bowell et al., 2014). Arsenic contamination is commonly released during mining and the roasting of orogenic gold ores because these ores contain As-bearing S ${ }^{2-}$ (Groves et al., 1998; Craw \& Bowell, 2014). The roasting and processing of As rich ores influence the mobility of As, as it generates mineralogical changes, which can alter As mobility, bioaccessibility and toxicity (Smedley \& Kinniburgh, 2002; Walker et al., 2015), creating a dangerous contaminant once it enters the surrounding environment.

In Yellowknife, NWT, Canada, the aerial emission from roasting As-bearing ores at local gold mines resulted in a large amount of As contamination in the surrounding environment and within the local lake sediments, that are far above Canadian environmental guidelines for sediment in order to protect fresh water aquatic life at $17 \mu \mathrm{g} / \mathrm{g}$ (Chételat et al. 2018; Galloway et al., 2018; Schuh et al., 2018; Van Den Berghe et al., 2018, CCME 2021). Ore roasting took place at Giant Mine from 1949 to 1999, to transform gold-bearing arsenopyrite into gold-bearing Fe oxides, so that gold could be extracted via cyanide leaching (Walker et al., 2015). The roasting process emitted $\mathrm{As}_{2} \mathrm{O}_{3}$ directly into the environment via a smokestack. Con Mine, another local gold mine that operated from 1938 to 2003, roasted ore from 1938 to 1970 and was an additional source of arsenic contamination within the area (Schuh et al., 2017). It has been estimated that $\sim 20,000$ tons of $\mathrm{As}_{2} \mathrm{O}_{3}$ were released into the environment by Giant Mine between 1949 and 1958. In 1958 a baghouse facility was constructed at Giant Mine to collect the $\mathrm{As}_{2} \mathrm{O}_{3}$ dust from the roaster 
emissions and direct atmospheric emissions were greatly reduced (Wrye, 2008). Tailings were piled on the shore of Yellowknife Bay from 1948-1951 resulting in transport of As contaminants directly into the Yellowknife Bay and Great Slave Lake. In addition, untreated effluent was released into Baker Creek from the start of operations until the construction of a wastewater treatment plant around 1980.

Arsenic contamination of water and sediments in the Yellowknife area was first studied by Wageman et al., in 1978. Since then, many studies have been conducted to assess the controls governing the distribution of As concentration within the area (Schuh et al., 2018; Palmer et al., 2019, 2020; Van Den Berghe, 2018, Galloway et al., 2017; Bromstad et al., 2017; Andrade et al., 2010), and the characterization of lake conditions that influence As mobility (Van Den Berghe, 2018). More recent studies have shown there is seasonal variation of As mobility from lake sediments that is influenced by climate and hydrology (Palmer et al., 2019, 2020). Arsenic contamination enters the overlying water by contaminated sediments (Andrade et al., 2010; Palmer et al., 2019). Research conducted by Andrade et al. (2010), on the biogeochemical redox cycling of As contaminated sediments in Yellowknife Bay determined that mine impacted lake sediments in the Yellowknife area acts as both a source and sink for mobile As, depending on the seasonal redox conditions. The study also showed that sediment pore waters in Yellowknife Bay act as a significant source of dissolved As, as the porewater develops a concentration gradient promoting the diffusion of As from the sediments into the overlying water (Andrade et al., 2010). Similarly, Palmer et al. (2019) measured that the concentration of As was much greater in the surface water of lakes near the mine, as sediments acted as a source of As to the water column, and the flux of As mobility was seasonally dependent. Palmer et al. (2019) also noted that the mobility of As 
depends on the physical characteristics of the lake and biogeochemical processes within the lake, and their study showed that lake depth acts as a control of As mobility because it affects dissolved oxygen availability. Shallower lakes have shown a greater seasonal change because of their physical and biogeochemical characteristics, such as more sunlight exposure to the sediments and less stratification, compared to deeper lakes (Palmer et al., 2019). Palmer et al. (2021) show that ice cover of subarctic lakes can influence the cycling of As. They determined that sediments were a source of As to the overlying water during oxygen-depleted periods in the winter in years where there is no water inflow to the lake. In winters when there was a hydrological connectivity, that changed the As cycling, due to the new presence of dissolved oxygen in the water column, which blocked the upward movement of a redoxcline into the overlying water column (Palmer et al., 2021). Previous studies have suggested that one of the key factors in controlling the mobilization of As is organic carbon (Barrett et al., 2019; Weber et al., 2010). Microbial decomposition of organic carbon requires oxygen or other electron acceptors, which in turn can lead to a reducing environment, allowing for As to mobilize from the sediments into the overlying water (Barrett et al., 2019). Since temperature has been shown to impact the mobility of As from sediments under reducing conditions (Barrett et al., 2019; Palmer et al., 2019; Li et al., 2020;), and temperature also influences microbial activity (Ratkowsky et al., 1982; Weber et al., 2010; Barrett et al., 2019), temperature is an important factor to study the influence on As mobility. Also, the presence of OM has shown to influence As mobility since it competes with As for binding sites (Galloway et al., 2018; Weber et al., 2010; Barrett et al., 2019), therefore the presence of OM is another important factor to study in regards to As mobility. 
With warming temperatures in the subarctic brought on by climate change, it is of interest to understand how temperature influences the mobility of legacy As contamination within lake sediments of the Yellowknife area. For this thesis two lakes were selected that had varied sediment composition. The sediments from Yellowknife Bay had a low OM content, and the sediments from Lower Martin Lake were rich in OM. By testing the sediments of these two lakes the effect of temperature on As diffusion was compared for lake sediments of different OM richness. The objective of this study was to determine the impact of temperature on well-oxygenated sediments from two lakes with different OM concentration. The hypothesis of this study was that warmer temperatures would increase the rate of the As flux from the contaminated sediments into the overlying water column, and the second hypothesis was that OM rich sediments from Lower Martin Lake will have the larger increase in the rate As flux of the two sediment types.

\subsection{Methods}

\subsubsection{Environmental Background and Study Site}

Lake water and sediment were collected from two lakes contaminated by mining pollution at Yellowknife, NWT, Canada. Lower Martin Lake and Yellowknife Bay on Great Slave Lake are in the southern area of the Slave Geological Province of the Canadian Shield (Wolfe et al., 2017). The climate of the area is continental subarctic, having long winters with the mean temperature in January being $-25.6^{\circ} \mathrm{C}$, and short warm summers with the mean temperature in July being $17.0^{\circ} \mathrm{C}$ (Environment Canada, 2018). Generally, the temperature remains below freezing from early October to mid-to-late April (Environment Canada, 2018). A study conducted by Galloway et al., (2018) measured the As concentration in the lake sediments within the Yellowknife Area and found the As concentration ranged from $5 \mu \mathrm{g} / \mathrm{g}$ to $>10,000 \mu \mathrm{g} / \mathrm{g}$ (median of $81.2 \mu \mathrm{g} / \mathrm{g}, \mathrm{n}=105$ ). 
The regional background As concentration in the lake sediments of the Yellowknife area was estimated to be approximately $25 \mu \mathrm{g} / \mathrm{g}$ (Galloway et al., 2015). Sediments from Yellowknife Bay consisted of clay mineral material with low $(<10 \%)$ organic content and a mean As concentration of $1700 \mu \mathrm{g} / \mathrm{g}$, whereas sediments from Lower Martin Lake had high organic content $(\sim 70 \%)$ and a mean As concentration of $822 \mu \mathrm{g} / \mathrm{g}$.

Great Slave Lake is the world's ninth largest lake in surface area, with an area of 28,568 $\mathrm{km}^{2}$. The lake is a cold-water, oligotrophic lake (Rawson, 1951), and is covered in ice from November to June (ECCC, 2018). Yellowknife Bay on the north arm of Great Slave Lake $\left(62.5102^{\circ} \mathrm{N}, 114.3189^{\circ} \mathrm{W}\right)$, has a surface area of $20 \mathrm{~km}^{2}$ and a maximum depth of $15 \mathrm{~m}$ at the north end (where the sediment sampling was done). Metal(loids) such as As and antimony, as well as copper, lead, manganese, mercury, silver, and zinc, from mining activities at Giant Mine were deposited into the north end of Yellowknife Bay via Baker Creek (Chételat et al., 2017). The greatest amount of As sediment contamination in Yellowknife Bay is found within $5 \mathrm{~km}$ of Giant Mine, then begins to decline exponentially with increased distance south of the mine (Chételat et al., 2017). Sediment cores retrieved from Yellowknife Bay have shown an increase in As concentration dated at the start of the mine operations (Andrade et al., 2010). In 1978, the As concentration of surface waters in Baker Creek which discharges directly into Yellowknife Bay and is a source of As for Yellowknife Bay was 1500 to 20,400 $\mu \mathrm{g} / \mathrm{L}$ (Moore et al., 1978). In a recent study Chételat et al. (2018) determined the peak sediment concentrations of As in the Yellowknife Bay was 741-4560 $\mu \mathrm{g} / \mathrm{g}$, which is approximately 180 times higher than the premining levels. At the north end of Yellowknife Bay where the sediment cores were collected, the As concentration in the surface water (in the late summer) was measured at $\sim 3 \mu \mathrm{g} / \mathrm{L}$, which is 
estimated at three to five fold higher than the measured background, and As in the surface water of Yellowknife Bay (in the late summer) was mainly inorganic As (Chételat et al. 2018).

Lower Martin Lake is a small lake with organic rich sediment, a maximum water depth of $2.9 \mathrm{~m}$ and an area of $1.21 \mathrm{~km}^{2}\left(62.512^{\circ} \mathrm{N}, 114.421^{\circ} \mathrm{W}\right)$ (Palmer et al., 2018). The depth of the lake is relatively consistent throughout the small basin (Palmer et al., 2019). The lake is within 5 $\mathrm{km}$ of the decommissioned roaster of Giant Mine, and is a natural waterbody situated outside the mine boundaries and northwest from the mine. Lower Martin Lake is a fish-bearing lake, however since it is shallow the fish are only present throughout the open-water season, because the lake goes anoxic during the winter, forcing the fish to either migrate or they die (Palmer et al., 2019). Lower Martin Lake is within the Baker creek watershed, which has a drainage area of about 155 $\mathrm{km}^{2}$ (Palmer et al, 2019). The Lower Martin Lake discharges through the Baker Creek system and flows through the Giant Mine property before finally flowing into the Yellowknife Bay of Great Slave Lake (Palmer et al, 2019). The As contamination found within Lower Martin Lake is from the aerial deposition of ore concentrate roasting occurring at Giant Mine (Van Den Berghe et al., 2018). The sediment surface area to water volume ratio is 0.8 , this large ratio enhances the impact the benthic processes have on the lake water conditions (Palmer al., 2019). Lower Martin Lake acts as a control on the legacy atmospheric mining pollutants flux entering Great Slave Lake since Lower Martin Lake flows into Baker Creek, which then discharges into Yellowknife Bay (Jamieson et al., 2017; Palmer et al., 2019). The surface water As concentration of Lower Martin Lake was $54.3 \mu \mathrm{g} / \mathrm{L}$ (Van Den Berghe et al., 2018). In previous studies Lower Martin Lake sediment cores showed a clear increase in As concentration beginning after approximately 1949 (Van Den Berghe et al., 2018). 


\subsubsection{Sediment and Lake Water Collection}

Duplicate sediment cores were collected using a gravity corer from Yellowknife Bay and Lower Martin Lake at a water depth of $\sim 8 \mathrm{~m}$ and $\sim 2 \mathrm{~m}$, respectively. The top $15 \mathrm{~cm}$ of the sediment was extruded from the Yellowknife Bay cores and transported unfrozen as a mixed bulk sample. The sediment cores from Lower Martin Lake were organic-rich, which allowed the cores to be frozen upright on the day of collection with minimal effect on the layering. Because of the high OM content, the cores maintained a relatively intact sediment profile after freezing. In contrast, the high clay and low OM content of the Yellowknife Bay sediment did not allow for freezing because previous attempts showed freezing excessively altered sediment characteristics. Surface water from the lakes was also collected following filtration with a high capacity 0.45 -micron filter, acidwashed Teflon tubing and a peristaltic pump. Filtered lake water was stored at $4{ }^{\circ} \mathrm{C}$ in acid-washed 1-4 L HDPE bottles. The surface water was collected to be used in the incubation experiment and for further analysis.

\subsubsection{Core Preparation}

The cores and water were shipped to Ottawa to carry out the laboratory experiment. The frozen Lower Martin Lake cores were thawed and left intact in the original core tubes used for their collection. In contrast, mixed sediment from the top $15 \mathrm{~cm}$ of the Yellowknife Bay cores was added to the bottom $10 \mathrm{~cm}$ of two new core tubes. Sediment from the four field collected cores were incubated in plastic core tubes $8.6 \mathrm{~cm}$ in diameter with filtered lake water added over top (initially $\sim 600 \mathrm{~mL}$ ). 
These sediments were placed in a temperature-controlled growth chamber. The growth chamber's lights were illuminated for 16 hours a day to mimic diurnal light exposure for the Lower Martin Lake sediment, which receives natural light under in situ conditions due to the lake's shallow depth. The lights recreated a natural diurnal light cycle that would occur in the respected lakes natural environment. Black plastic was used to entirely cover the Yellowknife Bay sediment (to mimic offshore deep-water conditions) and partially covered the Lower Martin Lake cores to prevent illumination of sub-surface sediment (Figure 3.1). Oxygen bubblers were placed in each core to pump oxygen into the cores and allow for aeration and mixing of the water, which is representative of the naturally oxygenated conditions in the study lakes. The bubbler flow remained at a constant rate throughout the experiment and was sufficiently above the sediment surface to avoid disturbance to the sediments. A porewater port was drilled into the sediment cores, at $\sim 1 \mathrm{~cm}$ below the sediment-water interface and sealed so that porewater samples could be extracted using a syringe. These cores were then incubated in a growth chamber at $5{ }^{\circ} \mathrm{C}$ for a 2 week period to allow the sediments and overlying water to equilibrate. After the 2-week equilibration period, the overlying water from the cores was gently removed using a large syringe and replaced with $1.5 \mathrm{~L}$ of fresh filtered lake water that was collected during fieldwork. The water was extracted and replaced slowly to avoid disturbing the top layer of the sediment as much as possible. The cores were then given a 48-hour period to allow any disturbed sediment to settle at $5{ }^{\circ} \mathrm{C}$. 


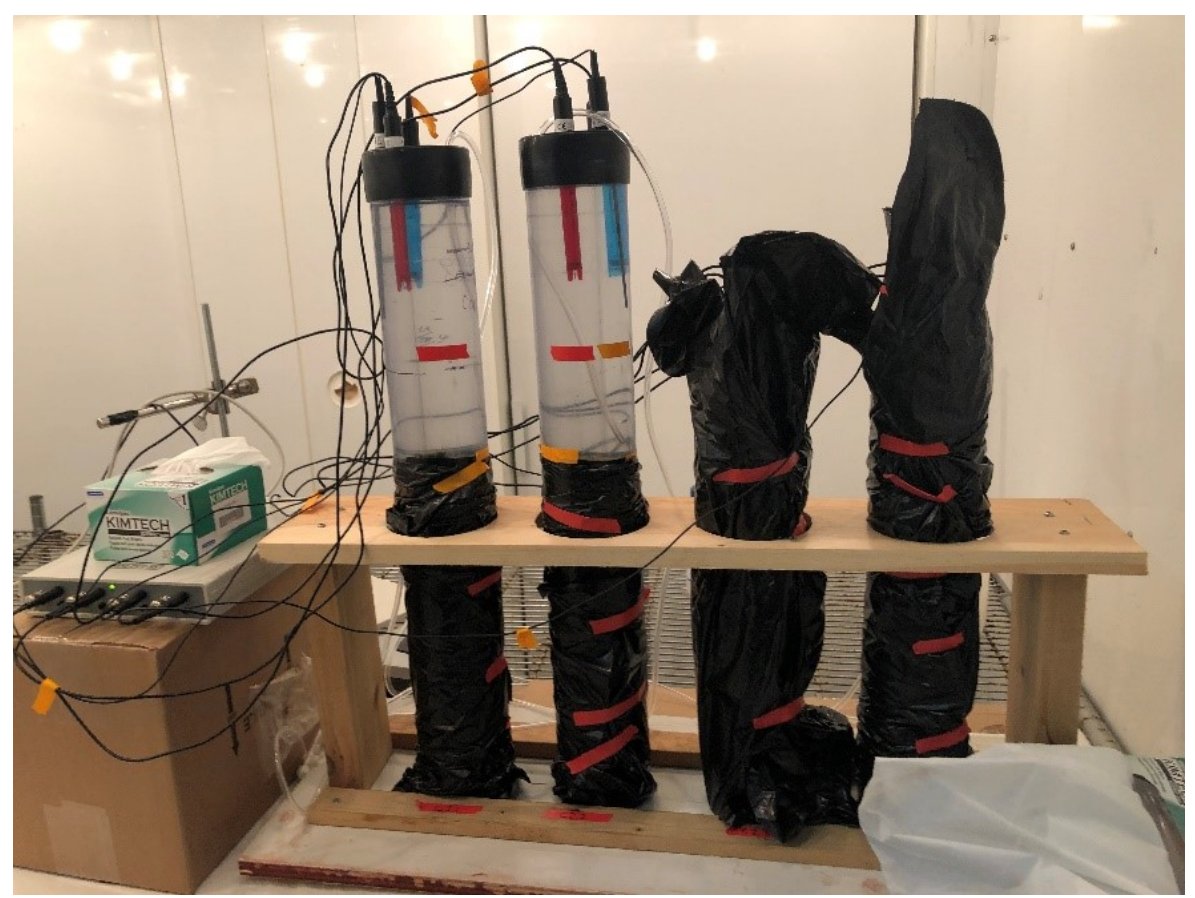

Figure 3.1: Incubated sediment cores from Yellowknife Bay of Great Slave Lake and Lower Martin Lake. Note the opaque plastic bags covering the sediments within each core to prevent algal growth except at the surface of the Lower Martin Lake sediment. Also, note the cap of each core with the wiring and drilled ports for the sensors for continuous measurement of temperature, $\mathrm{pH}$ and redox potential, and piping for an oxygen bubbler.

\subsubsection{Experimental Design}

The experiment took place over a 30 -day period and had 4 consecutive temperature treatments of approximately $5,10,15$ and 20 degrees Celsius, varying by $+2{ }^{\circ} \mathrm{C}$ due to the heat emitted from lights in the growth chamber (Table 3.1). Each treatment was approximately one week in length with 3 to 5 sampling days. Surface water was sampled multiple times throughout each treatment for As, iron (Fe) and manganese (Mn) concentration. Porewater As, Fe and Mn (Lower Martin Lake sediments only), and surface water for dissolved nitrogen (DN), DOC, and sulphate $\left(\mathrm{SO}_{4}{ }^{2-}\right)$ were sampled at the beginning and the end of each temperature treatment. Surface water was 
collected at the beginning and end of the experiment for analysis of a suite of 25 elements by ICPMS for background water chemistry (data provided in Appendix). In addition, general water quality variables (hardness, alkalinity, fluoride, chloride, magnesium, sodium, and potassium) were measured in the stock surface water added to the cores and in the surface waters at the end of the experiment (data and methods provided in the Appendix). For sampling at the end of the third temperature treatment of $15^{\circ} \mathrm{C}$, the temperature of the growth chamber was raised to $20^{\circ} \mathrm{C} \mathrm{a}$ day before the porewater, DN, DOC and $\mathrm{SO}_{4}{ }^{2-}$ water samples were collected. Those results were still used and assumed to be representative of measurements for the end conditions of $15^{\circ} \mathrm{C}$ temperature treatment. Sediment samples were collected from each core at the end of the incubation experiment for analysis.

Table 3.1: Experimental sampling schedule for surface water and porewater collection.

\begin{tabular}{|l|l|l|l|l|l|}
\hline Temperature & \multirow{2}{*}{$\begin{array}{l}\text { Average } \\
\text { Treatment } \\
\text { Realized } \\
\text { Temperature }\end{array}$} & \multicolumn{4}{|c|}{ Sampling Day } \\
\cline { 3 - 6 } & $\begin{array}{l}\text { Surface Water } \\
\text { As, Mn and Fe }\end{array}$ & $\begin{array}{l}\text { Surface } \\
\text { Water DN } \\
\text { and DOC }\end{array}$ & $\begin{array}{l}\text { Surface } \\
\text { Water SO }{ }_{4}^{2-}\end{array}$ & $\begin{array}{l}\text { Porewater } \\
\text { As, Mn and } \\
\mathrm{Fe}\end{array}$ \\
\hline $\begin{array}{l}\text { Treatment } 1 \\
\text { at } 5{ }^{\circ} \mathrm{C}\end{array}$ & $7{ }^{\circ} \mathrm{C}$ & $0,1,2,4,7$ & 0,7 & 0,7 & 0,7 \\
\hline $\begin{array}{l}\text { Treatment } 2 \\
\text { at } 10^{\circ} \mathrm{C}\end{array}$ & $12^{\circ} \mathrm{C}$ & $8,9,11,15$ & 15 & 15 & 15 \\
\hline $\begin{array}{l}\text { Treatment } 3 \\
\text { at } 15^{\circ} \mathrm{C}\end{array}$ & $16^{\circ} \mathrm{C}$ & $16,17,21$ & 22 & 22 & 22 \\
\hline $\begin{array}{l}\text { Treatment } 4 \\
\text { at } 20^{\circ} \mathrm{C}\end{array}$ & $21^{\circ} \mathrm{C}$ & $\begin{array}{l}22,23,24,28, \\
29\end{array}$ & 29 & 29 & 29 \\
\hline
\end{tabular}

\subsubsection{Surface Water Measurements}

The sensors used for temperature, $\mathrm{pH}$ and oxidation-reduction potential (ORP) were calibrated and connected to a laptop for continuous readings at 30-minute intervals using the 8-Channel Monitor/Data Logger (MM-PIT-8S) (EA Instruments Ltd., United Kingdom). The sensors used to 
measure $\mathrm{pH}$, temperature and ORP were also from ElectroAnalytical (EA Instruments Ltd., United Kingdom). The $\mathrm{pH}$ electrode (EAI pH2011) was calibrated at the start of the experiment using standard solutions of $\mathrm{pH} \mathrm{4,7}$ and 10. The teflon coated temperature sensor (EAI TS-NTC) had measurement range from 0.0 to $100.0{ }^{\circ} \mathrm{C}$ (NTC Thermistor, Siemens/Matsushita B57863-S104F9). The ORP electrode used was the ORP-31 C sensor that was calibrated at the start of the experiment using Zobell standard solution. Port holes were drilled into the cap of each core tube so that acid washed rhizons (product ID: 19.21.05, Rhizosphere, Netherlands) could be placed through the port to extract surface water samples via acid washed syringe without disturbing the underlying sediments. The rhizon sampler essentially acted as a $5 \mathrm{~cm}$ long cylindrical filter $(0.2$ $\mu \mathrm{m})$ and allowed for a more integrated sampling of the water column than with a syringe alone. Syringes washed in a $2 \%$ nitric acid $\left(\mathrm{HNO}_{3}\right)$ bath for a 48 -hours, then triple rinsed with ultra pure water and air dried over night. Rhizons were triple rinsed with $10 \mathrm{ml}$ of $2 \% \mathrm{HNO}_{3}$ followed by a triple rinse of ultra pure water.

Arsenic, $\mathrm{Mn}$ and Fe were measured in surface water samples to measure the metal(loid) efflux into the overlying water column of each core with each temperature treatment. Water samples of $5 \mathrm{~mL}$ were collected using rhizons, placed in $15 \mathrm{~mL}$ trace metal vials, preserved with $2 \% \mathrm{HNO}_{3}$, and stored in a refrigerator until analysis. Dissolved nitrogen and DOC were measured for indicators of OM breakdown and microbial activity. Water samples of $10 \mathrm{~mL}$ were placed in $20 \mathrm{~mL}$ glass vials that were pre-washed with $2 \% \mathrm{HNO}_{3}$ and combusted in a muffle oven at 425 ${ }^{\circ} \mathrm{C}$ for 2 hours. The samples were stored with no preservatives in a refrigerator until analysis. 
Samples extracted for $\mathrm{SO}_{4}{ }^{2-}$ concentration were measured to assess oxidation of sediment $\mathrm{S}^{2-}$. For the $\mathrm{SO}_{4}{ }^{2-}$ water samples, $2 \mathrm{~mL}$ of overlying water was stored in $15 \mathrm{~mL}$ trace metal vials, preserved with $2 \%$ zinc acetate, and stored in a freezer until analysis.

\subsubsection{Porewater Sampling}

Porewater samples were collected for analysis of As, Mn, and Fe concentration, and to assess the changes in porewater concentrations with temperature treatments. Due to the fine particle sizes of the Yellowknife Bay sediments, the syringes clogged, making porewater sampling impossible. Hence, porewater samples were only obtained from the two Lower Martin Lake cores. To preserve the porewater samples as quickly as possible, $2 \% \mathrm{HNO}_{3}$ was added prior to sampling directly to the syringe that was used to extract the porewater. A $0.45 \mu \mathrm{m}$ filter was added onto the syringe to prevent sediments from entering the porewater sample. Each $3 \mathrm{~mL}$ sample of porewater was stored in a $15 \mathrm{~mL}$ trace metal vial in a refrigerator until analysis.

\subsubsection{Sediment Sampling}

Once the experiment was completed, the sediments were collected from each core to analyze for bulk concentrations of 36 different metal(loid)s at Bureau Veritas (Vancouver, British Columbia, Canada). The cores were sliced using a UWITEC sediment extruder. Because the high OM content of sediments and low mass of material available from Lower Martin Lake, the top $3 \mathrm{~cm}$ of each core was collected to obtain sufficient material for analysis. The two Yellowknife Bay cores were sliced in intervals (the top $1 \mathrm{~cm}$ of sediment was collected as one sample, followed by $0.5 \mathrm{~cm}$ intervals of sediment slices to $5 \mathrm{~cm}$ depth). 
The sediment analysis had 3 blanks and a duplicate of one of the cores and there an analysis of certified reference materials to estimate recovery of those elements. Of the 3 blanks all 3 were below the method detection limit (MDL) $1 \mu \mathrm{g} / \mathrm{g}$ of $\mathrm{Mn}, 0.01 \%$ of Fe, and $0.02 \%$ of $\mathrm{S}$. In the blanks, 1 of the blanks had an As concentration above $0.1 \mu \mathrm{g} / \mathrm{g}$ at $0.2 \mu \mathrm{g} / \mathrm{g}$. Certified reference materials were used to estimate recovery. In the six standard reference material samples analyzed the average Mn and As concentration measured was $721.50 \pm 237.32 \mu \mathrm{g} / \mathrm{g}$, and $51.87 \pm 32.79 \mu \mathrm{g} / \mathrm{g}$, and the average Fe and S concentration measured was $3.24 \pm 0.22 \%$ and $0.32 \pm 0.16 \%$. Of the six reference materials three of the samples were of the STD OREAS262 certified concentration material (OREAS, 2019). The percent recovery of Mn, Fe, As, and S ranged from $92-100 \%$ for the STD OREAS262 samples. Two PACS Marine Sediment Reference Materials for Trace Metals and other constituents made by National Research Council of Canada, were analyzed as a QA/QC (Evisa, 2003). The two PACS had an average concentration of Mn and As of $243.5 \pm 4.95 \mu \mathrm{g} / \mathrm{g}$ and $23.7 \pm 0.28 \mu \mathrm{g} / \mathrm{g}$, and the concentration of $\mathrm{Fe}$ and $\mathrm{S}$ were measured at $3.03 \pm 0.06 \%$ and 1.23 $\pm 0.03 \%$. The two PACS-2 had a recovery percentage for Mn, Fe, As, and S at $55 \%, 74 \%, 90 \%$ and $95 \%$. Mn and Fe had a low recovery compared to the PACS- 2 certified values of $44 \mu \mathrm{g} / \mathrm{g}$ and $4.09 \mathrm{~g} / 100 \mathrm{~g}$, because only partial digestion was used for the analysis. Therefore, the recovery from the certified reference material for Mn and Fe is still satisfactory.

\subsubsection{Chemical Analysis}

Arsenic, $\mathrm{Mn}$ and Fe concentrations in water were measured by inductively coupled plasma mass spectrometry (ICP-MS) according to EPA method 200.8 at Taiga Laboratories (Yellowknife, Northwest Territories, Canada). Field blanks, travel blanks and field duplications were collected for quality assurance and quality controls $(\mathrm{QA} / \mathrm{QC})$ measures during the experiment. For the 
surface water sampling, a total of $21 \mathrm{QA} / \mathrm{QC}$ samples were taken: 8 field blanks, 6 travel blanks and 7 field duplicates. The average relative standard deviation (RSD) between duplicate samples for As, $\mathrm{Mn}$ and Fe were $1.5 \pm 1 \%, 8 \pm 17 \%$, and $6 \pm 9 \%$. Of the 8 field blanks, each one was below the MDL for As and Fe of 0.2 and $5.0 \mu \mathrm{g} / \mathrm{L}$, but 6 of the 8 field blanks measured a Mn concentration just above the MDL of $0.2 \mu \mathrm{g} / \mathrm{L}$, the average $\mathrm{Mn}$ concentration in the field blanks were $0.2 \pm 0.1 \mu \mathrm{g} / \mathrm{L}$.

Water was analyzed for DOC and DN at RPC Laboratories (Fredericton, New Brunswick, Canada) according to APHA $5310 \mathrm{~B}$, with a principal method of combustion and chemiluminescence by non-dispersive infrared (NDIR) detection. A total of 2 field blanks, 2 travel blanks and 3 duplicates were analyzed for both DN and DOC. There was contamination found in the field blanks for both DN (mean $=0.45 \mathrm{mg} / \mathrm{L}$, range $=0.3-0.65 \mathrm{mg} / \mathrm{L})$ and DOC $($ mean $=1.9$ $\mathrm{mg} / \mathrm{L}$, range $=1.5-2.3 \mathrm{mg}$ ), possibly due to the carbon-based filter of the Rhizon sampler. Sample results for DN and DOC were therefore corrected by subtracting the average concentrations in the field blanks. The average RSD of the duplicate samples was $9 \pm 9 \%$ for DN and $7 \pm 3 \%$ for DOC.

Sulphate was analyzed by ion chromatography on a Dionex instrument at the Geochemistry Laboratory (Department of Earth and Environmental Sciences, University of Ottawa, Ottawa, ON, Canada). The average RSD for $\mathrm{SO}_{4}{ }^{2-}$ for duplicate samples was $0.5 \pm 0.6 \%$. Each core was sampled for $\mathrm{SO}_{4}{ }^{2-} 5$ times, with core 1 having a duplicate done on day 0 and core 2 having a duplicate done on day 22. Both field blanks collected on day 7 and 15 were below the MDL of $0.07 \mathrm{mg} / \mathrm{L}$. 


\subsubsection{Data Analysis of Flux}

The fluxes of As, Fe, Mn for each temperature treatment were calculated for each core using the surface water masses of each element on the initial and final day of each temperature treatment (Equation 3.1). The mass of each metal(loid) was calculated using the measured concentration of each metal(loid) in $\mu \mathrm{g} / \mathrm{L}$ in the surface water samples multiplied by the estimated volume of the water column measured in liters. The mass of the metal(loid) of interest measured in $\mu \mathrm{g}$ on the final day of the temperature treatment was subtracted by the mass in $\mu \mathrm{g}$ measured on the first day of the temperature treatment, then divided by the duration of the treatment (days). Finally, to be divided by the area of the sediment surface $\left(0.00581 \mathrm{~m}^{2}\right)$. Regression analysis was used to examine the influence of temperature on the metal(loid) flux.

Equation 3.1: Flux equation $\left(\mu \mathrm{g} / \frac{m^{2}}{d a y}\right)$.

$\operatorname{Flux}\left(\mu \mathrm{g} / \frac{m^{2}}{\text { day }}\right)=\left[\frac{(\text { Final Mass }(\mu g) \text {-Initial Mass }(\mu \mathrm{g}))}{\text { (Final Day of Temprature Treatment - Initial Day of Temperature Treatment })}\right] \times$ (Sediment Surface Area $\left.m^{2}\right)^{-1}$

\subsubsection{Data Analysis using Fick's First Law}

Theoretical estimates of temperature effects on As flux were calculated for Lower Martin Lake using porewater As concentrations and Fick's First Law (Equation 3.2). Fick's First Law relates element flux to the diffusion coefficient of the sediment, the formation resistivity factor, the porosity of the sediments and the measured concentration gradient. 
Equation 3.2: Fick's first law equation.

$$
J z=-\left(\frac{D^{\circ}}{F} \times \varphi \times \frac{d c}{d z}\right)
$$

The diffusion coefficient $\left(D^{\circ}\right)$ is dependent on the viscosity of the water at the ambient temperature (Tanaka et al., 2013; Andrade et al., 2010). The ambient temperatures were set to mean temperature, in degrees Celsius, for each temperature treatment, represented by the coefficient $\mathrm{T}^{\circ}$. At $25^{\circ} \mathrm{C}$, the diffusion coefficient of arsenate is $8.75 \times 10^{-6} \mathrm{~cm}^{2} / \mathrm{s}$ with a viscosity of $1.42 \mathrm{mPa} / \mathrm{s}$ (Tanaka et al., 2013). The standard viscosity coefficient $\left(\mathrm{V}^{\circ}\right)$ of water at $25^{\circ} \mathrm{C}$ was used to interpolate the viscosity coefficient for each ambient temperature in Equation 3.3. These viscosity coefficients are then used to calculate the diffusion coefficient for each ambient temperature (Equation 3.4).

Equation 3.3: Water viscosity coefficient $(\mathrm{mPa} / \mathrm{s})$ at given temperature $\left({ }^{\circ} \mathrm{C}\right)$.

$$
V^{\circ}=1000 \times\left(\frac{2.414}{10^{5}}\right) \times 10^{\left(\left(\frac{247.8}{T^{\circ}+273.15^{\circ} \mathrm{K}}\right)-140\right)}
$$

Equation 3.4: Diffusion coefficient equation.

$$
\text { Diffusion }\left(D^{\circ}\right)=\frac{\left[\frac{D^{\circ} \text { at } 25^{\circ} \mathrm{C} \times \text { Viscosity at } 25^{\circ} \mathrm{C}}{25^{\circ} \mathrm{C}+273.15^{\circ} \mathrm{K}} \times\left(T^{\circ}+273.15^{\circ} \mathrm{K}\right)\right]}{\text { Viscosity at } T^{\circ}}
$$

The Porosity coefficient $(\varphi)$ is unitless and requires the sediment bulk density and the average particle density of Lower Martin Lake (Equation 3.5). The average particle density of Lower 
Martin Lake sediment was $0.8 \mathrm{~g} / \mathrm{cm}^{3}$. The sediment bulk density was based on the average densities of two 0-3 cm surface samples from Lower Martin Lake. The calculated average bulk density for Lower Martin Lake was calculated to be $0.01 \mathrm{~g} / \mathrm{cm}^{3}$. The bulk density is low because sediment of Lower Martin Lake is rich in OM and benthic algae. Using Equation 5, the porosity $(\varphi)$ was calculated to be 0.98 .

Equation 3.5: Porosity equation.

$$
\varphi=1-\left(\frac{\text { Sediment Bulk Density }}{\text { Average Particle Density }}\right)
$$

The Formation coefficient (F) is unitless and calculated using Equation 3.6. Equation 3.6 is used for organic rich sediments such as Lower Martin Lake and if $\varphi>0.7$. Given these assumptions, the Formation coefficient was calculated as $\mathrm{F}=1.04$.

Equation 3.6: Formation equation.

$$
F=\varphi^{-3}
$$

The average porewater and surface water concentrations from measurements on Day 0 and Day 7 (Table 3 in section 3.4.3) were used to calculate the concentration gradients $(\mathrm{dc} / \mathrm{dz})$ for each Lower Martin Lake sediment core and to calculate the theoretical effects of the temperature treatment on As flux (Equation 3.7). The distance of the gradient was $1 \mathrm{~cm}$. The final concentration gradient for core 1 and core 2 was calculated as $-0.0521 \mu \mathrm{g} / \mathrm{cm}^{3} / \mathrm{cm}$ and -0.0027 $\mu \mathrm{g} / \mathrm{cm}^{3} / \mathrm{cm}$. 
Equation 3.7: Concentration gradient equation $\mu \mathrm{g} / \mathrm{cm}^{4}$.

$$
\frac{d c}{d z}\left(\mu \mathrm{g} / \mathrm{cm}^{4}\right)=\frac{\frac{\text { Lower Water }[\mathrm{As}](\mu \mathrm{g} / \mathrm{L})-\text { Upper Water }[\mathrm{As}](\mu \mathrm{g} / \mathrm{L})}{\text { distance of gradient }(\mathrm{cm})}}{1000 \mathrm{~cm}^{3} / \mathrm{L}}
$$

Once the Diffusion $\left(\mathrm{D}^{\circ}\right)$, Porosity $(\varphi)$, Formation $(\mathrm{F})$ coefficients and the Concentration Gradient (dc/dz) were calculated, the predicted arsenic flux was calculated for each core with Equation 3.2 with a final unit of $\mu \mathrm{g} / \mathrm{cm}^{2}$ which was then converted to be reported as $\mathrm{g} / \mathrm{m}^{2} /$ day. The predicted flux calculated for core 1 and core 2 were then plotted against observed results for each temperature treatment.

\subsection{Results}

\subsubsection{Sediment Sampling}

The As concentration within the Lower Martin Lake sediment cores from $0-3 \mathrm{~cm}$ had an average concentration of $821.8 \mu \mathrm{g} / \mathrm{g} \pm 23.1 \mu \mathrm{g} / \mathrm{g}$. The average Mn concentration was $177 \pm 37 \mu \mathrm{g} / \mathrm{g}$. The average Fe concentration was $0.97 \pm 4.37 \%$. The concentration of S was $1.39 \pm 0.04 \%$ (Figure 3.2). The As concentrations in the Yellowknife Bay cores were high at a depth of $1 \mathrm{~cm}$ and decreased with depth. The average As concentration within the $5 \mathrm{~cm}$ sediment depth was 1674.26 $\pm 14.75 \mu \mathrm{g} / \mathrm{g}$. Similarly, $\mathrm{Mn}$ and Fe had a higher concentration at the $1 \mathrm{~cm}$ depth of the sediment and decreased with depth, however Fe began to increase close to the surface concentration at the $5 \mathrm{~cm}$ depth. The average Mn the concentration was $722.4 \pm 36.93 \mu \mathrm{g} / \mathrm{g}$, and for Fe the average concentration was $4.01 \pm 0.05 \%$. Sulphur was different then the other analytes as its lowest 
concentration was at a $1 \mathrm{~cm}$ depth and gradually increased with depth. The average concentration of $\mathrm{S}$ was $0.2 \pm 0.01 \%$.
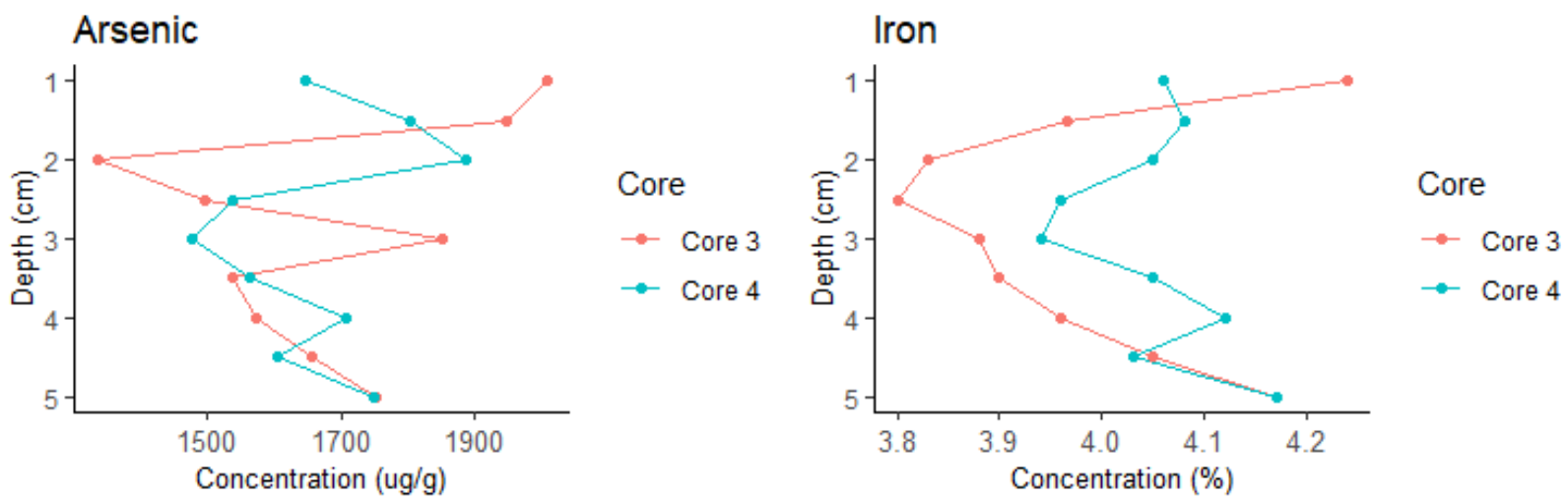

Manganese
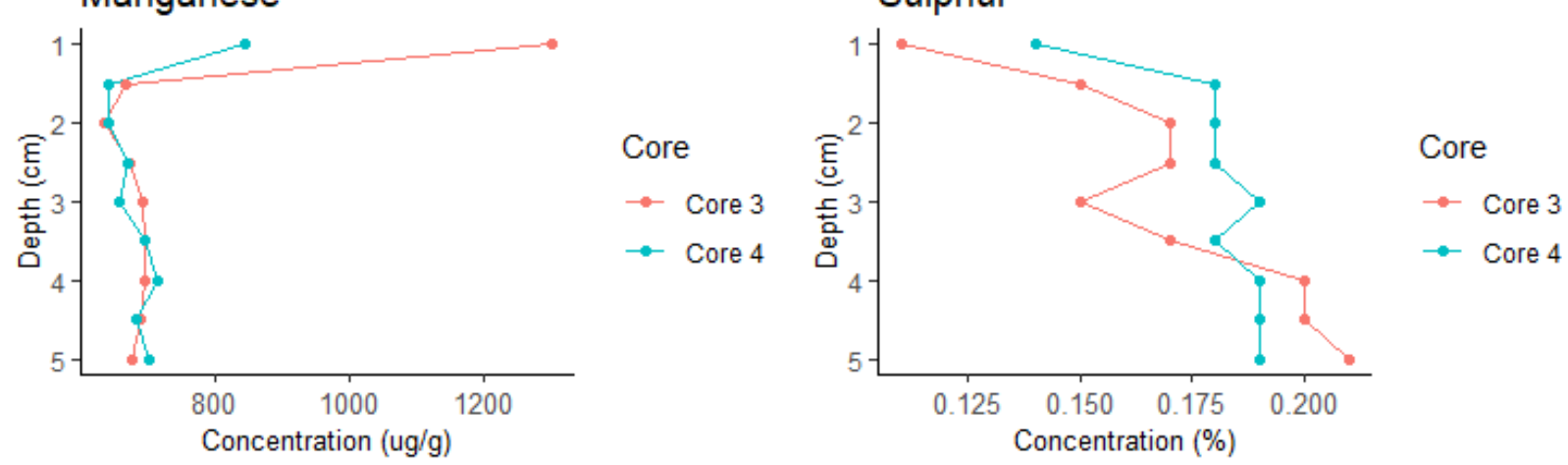

Figure 3.2: Sediment profile of the Yellowknife Bay cores from 1 to $5 \mathrm{~cm}$ depth. A duplicate of sediment of core 3 from $1-1.5 \mathrm{~cm}$ had an average RSD for $\mathrm{Mn}, \mathrm{Fe}$, As, and S below $<1 \%$.

\subsubsection{Surface Water Chemistry}

Arsenic concentrations in the overlying water were $34-58 \mu \mathrm{g} / \mathrm{L}$ in the Lower Martin Lake cores and 23-24 $\mu \mathrm{g} / \mathrm{L}$ in the Yellowknife Bay cores at the beginning of the experiment. The water As concentrations in all sediment incubations increased throughout the experiment, with approximately a two-fold increase in overlying water of the Lower Martin Lake cores and a threeto-four-fold increase in the Yellowknife Bay cores (Figure 3.3). One of the cores in Lower Martin Lake showed a greater increase than the other, while the cores of Yellowknife Bay showed almost 
identical increasing trends. The Fe concentrations in both sets of sediment cores remained relatively stable throughout the experiment with only slight fluctuations. The Mn concentration in Lower Martin Lake remained low and stable, where as the Mn in Yellowknife Bay had an overall decrease, especially in core 3 which showed a large range of 212 to $2.2 \mu \mathrm{g} / \mathrm{L}$.

Sulphate in the Lower Martin Lake cores remained low and changed little throughout the experiment, while in Yellowknife Bay cores $\mathrm{SO}_{4}{ }^{2-}$ concentration increased linearly throughout the experiment from 17.04 to $84.68 \mu \mathrm{g} / \mathrm{L}$ (Figure 3.4). Dissolved nitrogen (DN) increased slightly in the Lower Martin Lake cores, whereas there was negligible change in the Yellowknife Bay cores. Dissolved organic carbon remained high and steady in the Lower Martin Lake cores ( $\sim 15 \mathrm{mg} / \mathrm{L})$ and in one of the Yellowknife Bay cores slightly increased halfway through the experiment. The ORP indicated oxidizing conditions in the water column of all cores throughout the experiment. The ORP increased continuously in the Lower Martin Lake cores during the experiment, and in the Yellowknife Bay cores the ORP decreased at the beginning of the experiment and remained low for the remainder of the experiment. 

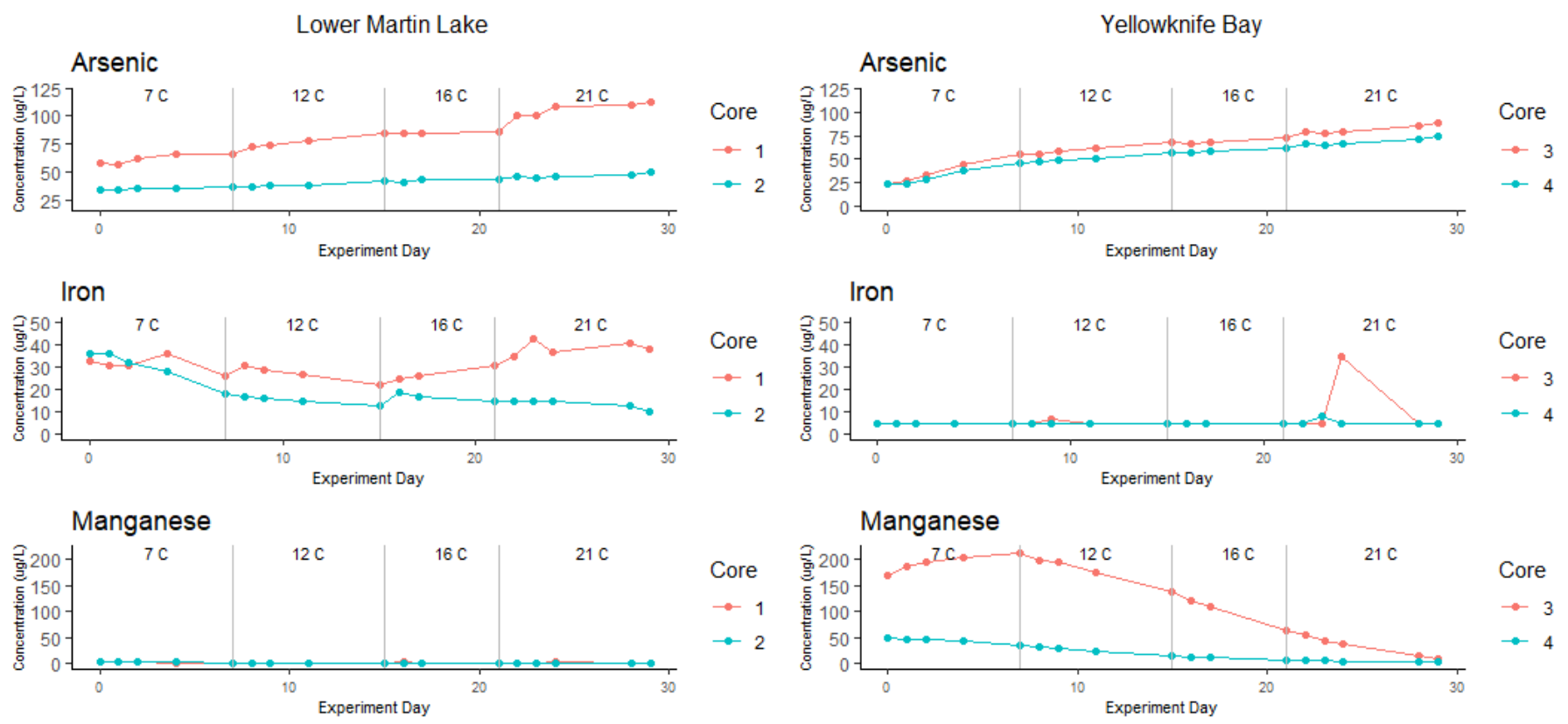

Figure 3.3: Metal(loid) concentration of As, Fe, and $\mathrm{Mn}$ in overlying surface water, within the Lower Martin Lake and Yellowknife Bay cores, throughout the 30-day experiment. Concentration is measured in $\mu \mathrm{g} / \mathrm{L}$. Each Grey line represents a new temperature treatment. The RSD of As, Fe, and $\mathrm{Mn}$ for all the duplicates were on average less than $8 \%$. 

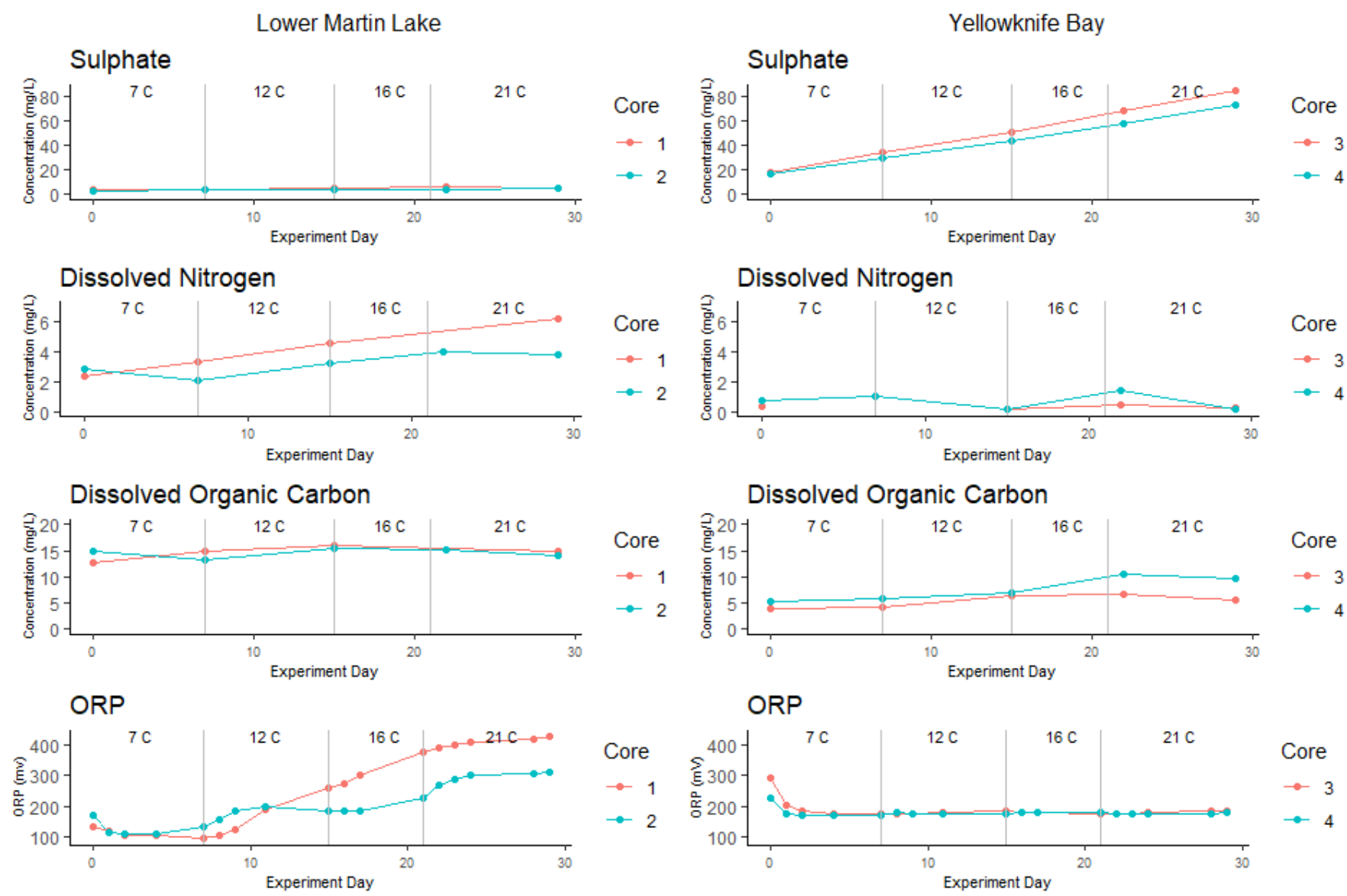

Figure 3.4: The concentration of $\mathrm{SO}_{4}{ }^{2-}, \mathrm{DN}$ and $\mathrm{DOC}$ and $\mathrm{ORP}$ of overlying surface water within the Lower Martin Lake and Yellowknife Bay cores, throughout the 30-day experiment. Each grey line represents a new temperature treatment. The RSDs for $\mathrm{SO}_{4}{ }^{2-}, \mathrm{DN}$, and DOC duplicates were $<1 \%$. 
Table 3.2: Chemical characteristics of overlying water during the sediment incubation experiment.

\begin{tabular}{|c|c|c|c|c|}
\hline & Metal(loid) & Mean & $\begin{array}{l}\text { Standard } \\
\text { Deviation }( \pm)\end{array}$ & Range \\
\hline \multirow{7}{*}{$\begin{array}{l}\text { Lower } \\
\text { Martin } \\
\text { Lake cores }\end{array}$} & As $(\mu g / L)$ & 61.6 & 25.3 & $33.9-112.0$ \\
\hline & $\mathrm{Fe}(\mu g / L)$ & 25.6 & 9.4 & $10.0-43.0$ \\
\hline & $\operatorname{Mn}(\mu g / L)$ & 1.5 & 1.0 & $0.2-4.1$ \\
\hline & $\mathrm{SO}_{4}{ }^{2-}(\mathrm{mg} / L)$ & 4.2 & 0.8 & $3.2-6.0$ \\
\hline & $\mathrm{DN}(m g / L)$ & 3.5 & 1.2 & $2.1-6.2$ \\
\hline & $\mathrm{DOC}(m g / L)$ & 14.5 & 1.1 & $12.8-16.0$ \\
\hline & ORP $(m V)$ & 225 & 107 & $98-426$ \\
\hline \multirow{7}{*}{$\begin{array}{l}\text { Yellowknife } \\
\text { Bay cores }\end{array}$} & As $(\mu g / L)$ & 56.6 & 18.6 & $22.6-89.0$ \\
\hline & $\mathrm{Fe}(\mu g / L)$ & 6.0 & 5.2 & $5.0-35.0$ \\
\hline & $\operatorname{Mn}(\mu g / L)$ & 73.4 & 74.3 & $2.2-212.0$ \\
\hline & $\mathrm{SO}_{4}{ }^{2-}(\mathrm{mg} / L)$ & 47.6 & 23.1 & $17.0-84.7$ \\
\hline & $\mathrm{DN}(m g / L)$ & 0.6 & 0.4 & $0.2-1.4$ \\
\hline & $\operatorname{DOC}(m g / L)$ & 6.5 & 2.2 & $3.8-10.5$ \\
\hline & ORP $(m V)$ & 183 & 21 & $171-290$ \\
\hline
\end{tabular}

\subsubsection{Surface Water Metal(loid) Fluxes}

The metal(loid) flux results were different then what was predicted based on previous studies (Andrade et al., 2010; Weber et al., 2010; Van Den Berghe et al., 2017; Schuh et al., 2019; Palmer et al., 2019; Barrett et al., 2019; Johnston et al., 2020; Li et al., 2020). Duplicate measurements of metal(loid) fluxes from sediments of Lower Martin Lake and Yellowknife Bay showed little variation among temperature treatments (Figure 3.5; Table 3.3). The As fluxes to overlying water from organic rich sediments in the Lower Martin Lake cores did not change with temperature, while the fluxes from OM poor sediments of Yellowknife Bay were the highest at the start of the experiment (with the coldest temperature treatment) then decreased in warmer temperature treatments. The aqueous diffusion rate of Fe in the Lower Martin Lake cores decreased over the experiment remaining in a negative flux almost approaching a zero flux and continuously settled out during the experiment, while there was no Fe flux in the Yellowknife Bay cores. The Mn flux did not change with increasing temperature in both the Lower Martin Lake and Yellowknife Bay 
cores. However, there was a negative flux(settling out), or no flux, of Fe and $\mathrm{Mn}$ in all the cores across the temperature treatments over time.
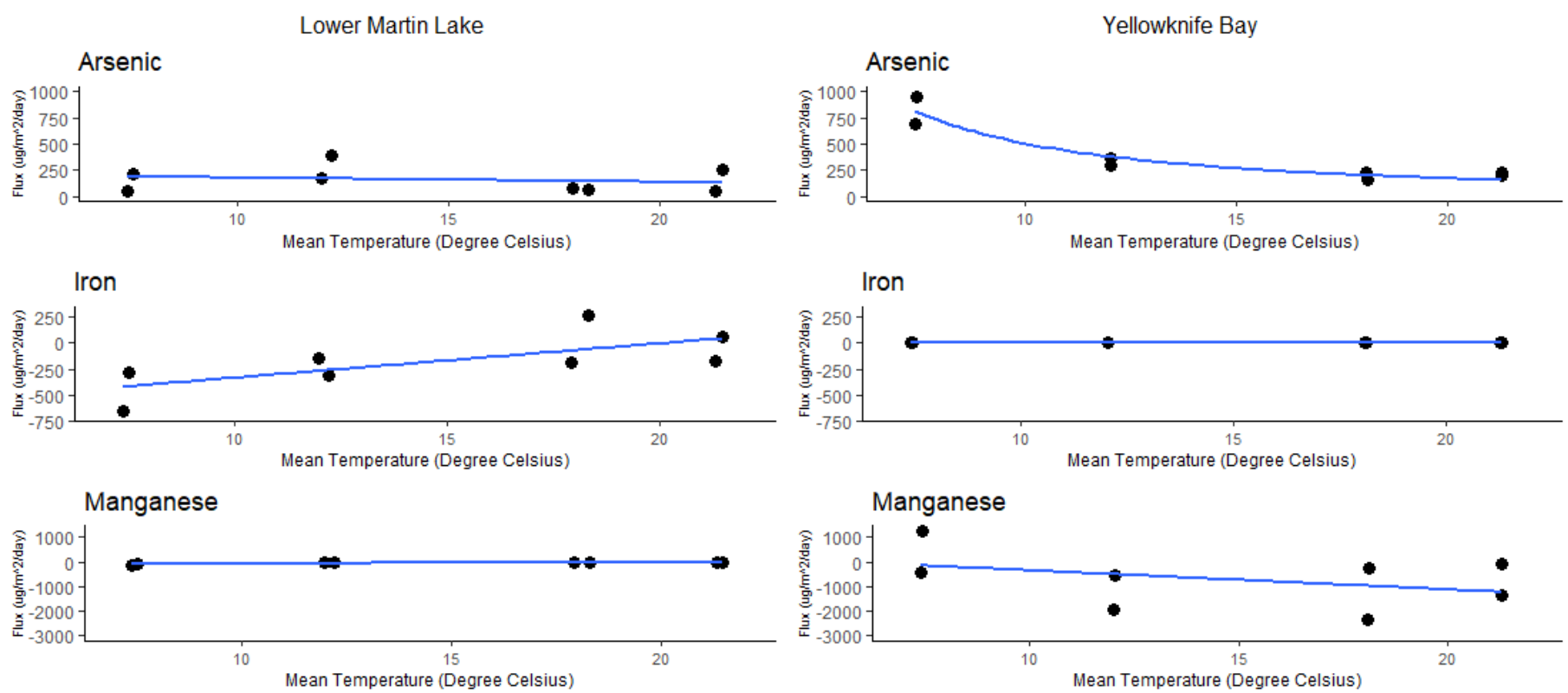

Figure 3.5: Metal(loid) fluxes between overlying water and sediment from Lower Martin Lake and Yellowknife Bay incubated at different temperatures. There are two points for each temperature treatment as they represent the calculated flux within duplicate lake cores at the respected temperature treatment.

Table 3.3: Metal(loid) flux estimates ( $\mu \mathrm{g} / \mathrm{m}^{2} /$ day) from Yellowknife Bay and Lower Martin Lake sediments, averaged across temperature treatments.

\begin{tabular}{|lcccc|}
\hline & \multicolumn{2}{c}{ Lower Martin Lake } & \multicolumn{2}{c|}{ Yellowknife Bay } \\
\hline Metal(loid) & $\begin{array}{c}\text { Mean }( \pm \text { Standard } \\
\text { Deviation) }\end{array}$ & Range & $\begin{array}{c}\text { Mean ( } \pm \text { Standard } \\
\text { Deviation) }\end{array}$ & Range \\
\hline As & $159 \pm 122$ & 48 to 387 & $392 \pm 284$ & 164 to 956 \\
$\mathrm{Fe}$ & $-178 \pm 270$ & -657 to 261 & $-3 \pm 1$ & -4 to -2 \\
$\mathrm{Mn}$ & $-46 \pm 44$ & -139 to -10 & $-717 \pm 1143$ & -2359 to 1247 \\
\hline
\end{tabular}




\subsubsection{Theoretical Estimates of Temperature Influence on Arsenic Flux from Lower Martin Lake Sediment}

The average porewater As concentration for all sampling dates were core 1 was $104.6 \pm 13.9 \mu \mathrm{g} / \mathrm{L}$ and in core 2 was $44.4 \pm 9.6 \mu \mathrm{g} / \mathrm{L}$. The average Fe concentration for all sampling dates in core 1 was $45.6 \pm 24.8 \mu \mathrm{g} / \mathrm{L}$ and in core 2 was $513.0 \pm 244.8 \mu \mathrm{g} / \mathrm{L}$. The average porewater for all sampling dates concentration of $\mathrm{Mn}$ in core 1 was $15.2 \pm 19.2 \mu \mathrm{g} / \mathrm{L}$ and in core 2 was $226.0 \pm$ 81.1 $\mu \mathrm{g} / \mathrm{L}$. There was a high Fe and Mn concentration in core 2, but not in core 1. This suggests that there were reducing conditions at a depth of $1 \mathrm{~cm}$ below the SWI in core 2 but not in core 1 .

To calculate the theoretical flux of As in the Lower Martin Lake cores, the concentration gradient of As was used. The average porewater concentration of As in core 1 and core 2 on days 0 and 7 were 112.5 and $37.4 \mu \mathrm{g} / \mathrm{L}$, and the average surface water As concentration on day 0 and 7 were 60.4 and $34.7 \mu \mathrm{g} / \mathrm{L}$. Using Fick's law, the theoretical estimates of temperature effects on the As flux of Lower Martin Lake were calculated at the mean temperature for each treatment, 7, 12, 16 and 21 degrees Celsius. This calculation did not account for temperature influences on biogeochemical reactions. As seen in Figure 3.6, the theoretical arsenic diffusion rate predicted by Fick's Law increased positively with warmer temperature. The Fick's Law estimates for As flux increased by a factor of 1.6 times between 7 and $21{ }^{\circ} \mathrm{C}$ for both cores. The observed As fluxes in the Lower Martin Lake cores did not increase with temperature but were scattered near to the theoretical flux predictions. The mean predicted flux for core 1 was $277 \pm 49 \mu \mathrm{g} / \mathrm{m}^{2} /$ day with a range of 221 to $335 \mu \mathrm{g} / \mathrm{m}^{2} /$ day and the observed mean flux was $231 \pm 134 \mu \mathrm{g} / \mathrm{m}^{2} /$ day with a range of 61 to $387 \mu \mathrm{g} / \mathrm{m}^{2} /$ day. The mean predicted flux in core 2 was $14 \pm 3 \mu \mathrm{g} / \mathrm{m}^{2} /$ day with a range of 11 to $17 \mu \mathrm{g} / \mathrm{m}^{2} /$ day and the observed mean flux was $87 \pm 56 \mu \mathrm{g} / \mathrm{m}^{2} /$ day with a range of 48 to 
$168 \mu \mathrm{g} / \mathrm{m}^{2} /$ day. Since the As concentration gradient between sediment porewater and overlying water in Core 2 was lower than in Core 1, the theoretical temperature effect was lower.
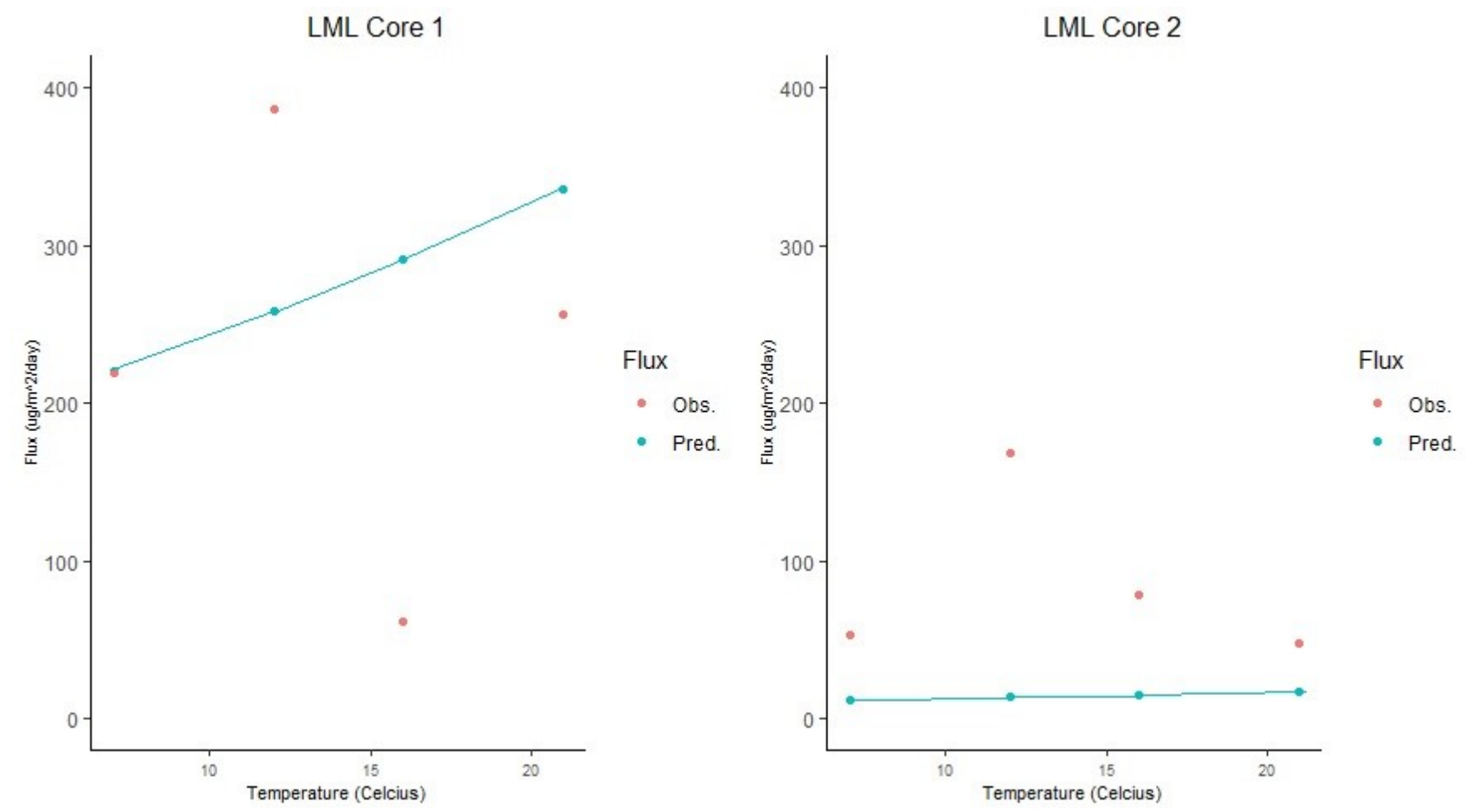

Figure 3.6: Predicted arsenic flux of the Lower Martin Lake cores calculated using Fick's Law, versus the measured As flux in those cores. The flux is measured in $\mu \mathrm{g} / \mathrm{m}^{2} /$ day and temperature is measured in degrees Celsius.

\subsection{Discussion}

\subsubsection{Temperatures Influence on Arsenic Flux}

Despite an increase in As concentration in the overlying water throughout the experiment, there was no detected influence of temperature on the As flux for the two different types of sediment from the two contaminated lakes (Figure 3.3 \& 3.5). Yellowknife Bay had a higher sediment As 
concentrations of $1674.3 \mu \mathrm{g} / \mathrm{g}$, compared to Lower Martin Lake As concentration of $821.8 \mu \mathrm{g} / \mathrm{g}$, which can explain the higher fluxes seen in the Yellowknife Bay cores (Figure 3.3 \& 3.5). It is possible there was a small temperature effect that was not detected due to measurement error; however, the predicted theoretical effect was small (Figure 3.6). These results suggest that temperature alone (over the range tested in this experiment) had little to no affect on the As flux for both lake sediments. By controlling redox conditions over overlying water and preventing temperature-driven microbial oxygen depletion in the sediment surface layer at warmer temperatures, the experimental results indicate that temperature effects on As sediment flux, which have been reported in previous studies (Andrade et al., 2010; Barrett et al., 2019; Johnston et al., 2020; Li et al., 2020; Schuh et al., 2019), are likely due to indirect effects on redox conditions.

It has been shown in previous studies that near-surface Fe(oxy)hydroxides absorb a considerable amount of As (3-4 wt \%) (Schuh et al., 2018; Van Den Berghe et al., 2018). Multiple laboratory-based studies have shown that As mobility in saturated soils and sediments under reducing conditions is temperature dependent, as there was an increase in reduction of As(V) (Bonte et al., 2013; Lüders et al., 2020; Simmler et al., 2017; Weber et al., 2010). Also, the reduction of $\mathrm{Fe}(\mathrm{III})$ oxide minerals is temperature dependent (Meier et al., 2005; Pallud et al., 2020; Schilling et al., 2019), and increasing temperature in reducing environments will impact any As bound to Fe(III) oxides (Johnston et al., 2020). In typical seasonal anoxic conditions, the As in the surface water would increase during late-winter, because of the seasonal desorption/dissolution from the Fe(oxy)hydroxides, this layer would remove the oxic boundary in the near surface sediments (Palmer et al., 2019). This is relevant to a temperature effect as it demonstrates that even at a low temperature the removal of this oxic barrier and the development of a reducing condition 
will allow for a release of As into the overhead water column. In this experiment the As flux did not increase with the increasing temperature, because unlike previous studies the sediment surface layer likely remained in a oxic state throughout the experiment (Figure 3.5). Other studies have shown that the aerobic zone in the near-surface sediment can function as a barrier layer to As diffusion across the sediment-water interface (Andrade et al., 2010; Bennett et al., 2012; Martin \& Pedersen, 2004). This aerobic barrier layer could be the cause of the lack of an increase in As flux at warmer temperatures (Figure 3.5).

Previous studies have shown that an increase in $\mathrm{As}, \mathrm{Fe}$, and $\mathrm{Mn}$ concentration within surface water occurs with the onset of anoxia, influencing an increase in sediment efflux (Palmer et al., 2019). There was likely no dissolution of Fe and Mn oxyhydroxides, as these metals showed either little to no change in overlying water, or a negative flux indicating a settling out with increasing temperature (Figure 3.3 \& 3.5). The concentration in surface water from regional lakes that had higher OM had a higher internal loading of As from lake sediments (Palmer et al., 2018). Sediments rich in $\mathrm{OM}$ will influence the location of the $\mathrm{Fe}(\mathrm{III})$ redoxcline boundary within the lake sediment due to there being a high oxygen demand and microbial respiration within the sediments (Palmer et al., 2018). The As flux can also increase if the aerobic layer that is located within the sediments near the sediment-water interface was too thin. When this layer thins, As will begin to move upward as it desorbs from the Fe oxy(hydroxides), creating a As sediment flux (Martin \& Pedersen, 2004). Organic matter building up promotes reducing conditions, allowing $\mathrm{SO}^{2-}{ }_{4}$ to be reduced, and leading to a higher mobility in As in sediment porewaters caused by the precipitation of $\mathrm{As}_{2} \mathrm{~S}_{3}$ (Johnston et al., 2020). Sulphate reduction is a sign of reducing conditions (Johnston et al., 2011). 
Typically, as temperature increases so does the microbial respiration, resulting in a decreased sediment oxic layer, and leading to the reductive dissolution of Fe-oxyhydroxides, which allows for an increase in As concentration from an increase in As flux from the sediment into the overlying surface water due to a release of bound As (Barret et al., 2019). An increase in temperature and nutrient input promotes algal growth, this algal growth leads to a larger amount of organic carbon to enter the lake sediments (Barrett et al., 2019). This organic carbon fuels microbial metabolism allowing a release in As and a reduction of Fe; a reduction of Fe leads to the desorption of As from solid surfaces, leading to a release in As (Barrett et al., 2019). Once phytoplankton that took up As die and sink into the lakes sedimented, or are eaten by zooplankton, the As is returned to the sediment layer, therefore in shallow lakes As fluxes are correlated with As sedimentation rates (Barrett, et al., 2019). However, the DN and DOC concentration did not increase with temperature, suggesting there was no increase in microbial activity within these sediment cores. This is interesting because Lower Martin Lake sediments were partly composed of benthic algae, which would have been photosynthesizing, creating dissolved oxygen as a byproduct. This could be a possible explanation for the increase in ORP in Lower Martin Lake over the course of the experiment (Figure 3.4).

Although inorganic As speciation was not measured in this study, a study conducted by Weber et al., (2010) acknowledged that As speciation is important and $\mathrm{As}(\mathrm{V})$ has greater adsorption potential. In their study they monitored the formation of Fe(II) and As(III) within the porewater of contaminated floodplains. They incubated air-dried soil samples in synthetic river water for periods between 1 and 52 days with increasing temperature and underwent three different temperature treatments beginning at $23{ }^{\circ} \mathrm{C}$, then $14{ }^{\circ} \mathrm{C}$ and ending at $5{ }^{\circ} \mathrm{C}$. It was noted that 
dissolved As was linearly correlated with $\mathrm{Fe}$, and increased with warmer temperature in the study, however the rise in concentration acted independently from temperature (Weber et al., 2010). The flooding of the contaminated soil created reducing conditions which promoted the increase in $\mathrm{Fe}(\mathrm{II})$ and As(III) concentrations. The mobilization of As in sediment and soils occur in anoxic conditions, which promotes microbial $\mathrm{Fe}$ and As reduction. Under anoxic conditions, temperature had a large influence on the concentrations of dissolved Fe(II) and As(III) (Weber et al., 2010). Arsenite formation is linearly correlated the formation of $\mathrm{Fe}(\mathrm{III})$ in reducing conditions, this shows that microbial $\mathrm{Fe}(\mathrm{III})$ hydroxide reduction rate is directly corelated to $\mathrm{As}(\mathrm{V})$ reduction (Weber et al., 2010). Temperature may have impacted temporal dynamics of Fe and As, however, the main driver in the rise in As concentration and flux was the reducing conditions (Weber et al., 2010). The dissolved-phase dynamics of As and Fe are controlled by the reductive transformation of readily available $\mathrm{Fe}(\mathrm{III})$ and $\mathrm{As}(\mathrm{V})$. Physical processes driven by temperature can lead to an increase in As mobility. Arsenate will sorb to goethite, and the sorption will become increasingly weaker with increasing temperature (Kersten \& Vlasova, 2009). Previous studies have shown that As(III) will desorb from sediments with increased temperature (Bonte et al., 2013). This is because $\mathrm{As}(\mathrm{V})$ and $\mathrm{As}(\mathrm{III})$ will compete with each other and with $\mathrm{HCO}_{3}{ }^{-}$to sorb onto goethite (Stachowicz et al., 2007). Over short periods of time, temperature is not a driver of As mobility, but the long term impact it has on redox potential on a seasonal scale is a major factor (Johnston et al., 2020).

In oxic condition, $\mathrm{As}(\mathrm{V})$ in floodplain soil is linked to poorly crystalline $\mathrm{Fe}(\mathrm{III})$ (hydroxides), which is caused by As(III) oxidizing with Fe(II) during aeration (Voegelin et al., 2007). Webber et al, (2010) suggests that reductive dissolution of poorly crystalline $\mathrm{Fe}(\mathrm{II})$ hydroxides frees $\operatorname{As}(\mathrm{V})$, which is typically blocked, and allowing it to be obtainable for 
microorganisms. Thus reductive dissolution of Fe(III) (hydr)oxides is the limiting factor in microbial reduction of $\mathrm{As}(\mathrm{V})$ (Zobrist et al., 2000). Under neutral and slightly acidic conditions $\mathrm{As}(\mathrm{V})$ sorption is stronger then $\mathrm{As}(\mathrm{III})$, due to their being a lack of competing ions (Robert et al., 2004; Stachowicz et al., 2003; Dixit \& Hering, 2003), so that the reduction of As(V) to As(III) leads to an increased in net dissolved As. An important driver of As mobility is the reduction of As(V) species accompanied by the desorption of newly formed As(III) (Borch et al., 2010). Under neutral and near neutral conditions with low to moderate loadings, As(III) has a lower sorption affinity than $\mathrm{As}(\mathrm{V})$ to sediment and soil particles (Johnston et al., 2020). Evidence of this was seen through the correlations to carbon dioxide $\left(\mathrm{CO}_{2}\right)$ levels, temperature, the redox potential and As(III), indicating that it is not temperature that controlled As mobility, but that microbial carbon metabolism is the main driver of $\mathrm{As}(\mathrm{V})$ reduction to As(III) (Rouwane, et al., 2016).

Li et al., (2020) conducted a batch experiment on mine contaminated sediments collected from the Huangshui Creek in Hunan Province, China. In their experiment sediment samples were incubated and underwent 3 temperature treatments of $8^{\circ} \mathrm{C}, 25^{\circ} \mathrm{C}$ and $37^{\circ} \mathrm{C}$. In this experiment they saw an increase in As concentration with temperature, specifically an increase of As(III) mobility from the sediments (Li et al., 2020), similarly seen in Fernandez et al., (1996). This study suggests that As contaminated sediments will supply As at warmer temperatures (Li et al., 2020). This differs from what was seen in this thesis. Biogeochemical cycling of As is influenced by factors such as $\mathrm{pH}$, Eh, ionic strength and microbial activity (Li et al., 2020). The speciation of As is influenced by photooxidation, microbial Fe, Mn, and oxidation and reducing conditions (Ahmann et al., 1994; Mackway et al., 2014). Li et al., (2020) study showed that temperature and As concentration were the major controls for microbial community, and As mobility from sediments 
increased with increasing temperature. However, Li et al., (2020) did not address sediments incubated in a well oxygenation environment.

Similarly, a study conducted by Johnston et al., (2020), sediment from the Macleay River catchment in the United States was collected and incubated for 21 days at five temperature treatments at $8{ }^{\circ} \mathrm{C}, 14{ }^{\circ} \mathrm{C}, 20^{\circ} \mathrm{C}, 26{ }^{\circ} \mathrm{C}$ and $32{ }^{\circ} \mathrm{C}$, as it matches the temperature range in the Macleay River. Their study showed that temperature alone had a negligible impact on As mobility under oxic conditions, but that temperature had a indirect influence on reducing conditions (Johnston et al., 2020). New aspects that must be considered for future studies is the impact dissolved oxygen has on As mobility with varying temperatures, and the indirect effects temperature has of microbe respiration rates, which can drive redox conditions (Johnston et al., 2020). In Johnston's et al. (2020) study there was an increase in As(III) species towards the end of the experiment when sediment was at the highest temperature treatment and in reducing conditions. This is to be predicted as the reduction of $\mathrm{As}(\mathrm{V})$ is thermodynamically more favourable than the reduction of both $\mathrm{Fe}(\mathrm{III})$ and $\mathrm{SO}_{4}{ }^{2-}$ (Kocar \& Fendorf, 2009). Temperature is a key parameter in the redox-sensitive biogeochemical process, but only if the environment is already under reducing conditions (Johnston et al., 2020). Arsenate is typically found in oxic environments, and it will interact with sediment particles via adsorption, decreasing its aqueous activity (Campbell \& Nordstrom, 2014). Arsenite is dominant in reducing conditions, allowing it to be more mobile then As(V) (Arsic, et al., 2018; Burton et al., 2008; Diwakar et al., 2015; Fendorf, Michael, et al., 2010; Johnston et al., 2010, 2020). 
Despite the difference in geochemical structure of sediment between lakes, there was no change in As fluxes with increasing temperature in sediments from either lake, as seen in this experiment. However, this has been seen in previous studies that difference in geochemical properties between lakes both have an increase in sediment temperature has seen similar increase in As fluxes (Barrett et al., 2019). However, the increase in As in Barrett et al., (2019) study is due to the sediment cores remaining under reducing conditions throughout the experiment.

Arsenic found within lake sediments is associated with Fe-(hydro) oxides, because As will either sorb or co-precipitate with the iron-(hydro)oxides (Ferguson \& Gavis, 1972). Arsenic coprecipitates with Fe oxides, so when Fe begins to reduce As is released (Loeppert \& Inskeep 1996). Arsenic (As) can enter porewater in multiple ways. One way is through competitive ion desorption for the sediment particles (Smedley \& Kinniburgh, 2002). The second way is through reductive dissolution of Fe-oxide mineral, which occur in a anaerobic environment with high microbe activity, which oxidizes organic carbon thought reducing Fe(III) (Smedley \&K Kinniburgh, 2002; Barrett et al., 2019). Once the As can travel within the sediment porewater, it will move into the overlying water column through either molecular transport, or turbulent diffusion (Barrett et al., 2019). Previous studies have considered that high bottom water temperatures and sediment temperatures promote the mobilization of As, due to the increase in microbial respiration which stimulates the increase in As flux during organic carbon oxidation (Barrett et al., 2019). The oxidize form of $\mathrm{As}, \mathrm{As}(\mathrm{V})$, is particle reactive, $\mathrm{As}(\mathrm{V})$ will move out of oxic water, and tends to sorbs onto other settling particles and sediments (De Vitre et al., 1991; Dixit \& Hering, 2003; Tufano \& Fendorft 2008), it is this particle reactivity that causes As concentration to remain low in oxic waters (Smedley \& Kinniburgh, 2002). However, it has been seen that in shallow well 
mixed lakes, the As concentration will remain high in summer months (Smedley \& Kinniburgh 2002). Barrett et al, (2019) suggested that the key component that influences As flux in oxic water is biological activity. Biological activity is one of the key factors influencing As flux in oxygenated conditions because phytoplankton take up $\mathrm{As}(\mathrm{V})$ along with phosphate due to the similarity in its molecular shape, resulting in phytoplankton becoming a key transport for As (Rahman et al., 2012). This phytoplankton As uptake is the primary entry point of As into the aquatic food web (Chen \& Folt 2000; Chen et al., 2000; Erickson et al., 2011). Once the phytoplankton have died or been eaten by zooplankton, their biomass sinks down to the sediments, returning the As back to the sediments (Barrett et al., 2019). During periods of excess phosphorus availability within lakes, typically seen during the early onset of algae blooms, algae will take up the phosphorus, and therefore there will be an increase uptake in $\mathrm{As}(\mathrm{V})$ (Hellweger et al., 2003; Hellweger \& Lall 2004). In the summer, phosphorus becomes a limited nutrient, therefore $\mathrm{As}(\mathrm{V})$ and phosphate compete for uptake sites on the algae membranes, thus the (As) uptake rate is opposite to the phosphate-to-As(V) ratio (Sanders \& Windom, 1980).

During long period of anoxia, as seen in seasonally stratified lakes, $\mathrm{S}^{2-}$ generation will promote the precipitation of $\mathrm{As}_{2} \mathrm{~S}_{3}$ minerals (Moore et al., 1988; Harington et al., 1998). When lakes become well mix and oxygenated, such as lakes at the end of stratifications, the As and $\mathrm{Fe}$ will begin to oxidate, facilitating the scavenging of $\mathrm{As}(\mathrm{V})$ onto Fe-rich particles that have settled onto the lake sediments (Hartland et al., 2015). In previous research, seasonal variations in suboxic sediment zones of highly contaminate lakes, saw an increase in elevated porewater As concentrations as the temperature increased (Toevs et al., 2008; Andrade et al., 2010; Van Den Berghe et al., 2018). In a study conducted by Barrett et al., (2019) a seasonal increase in bottom 
water temperatures resulted in an increase in porewater As concentration. This is due to an increase in microbial activity brought on by an increase temperature of $>20^{\circ} \mathrm{C}$, which influences the As released cause by the dissimilatory reduction of Fe-oxides (Barrett et al., 2019).

\subsubsection{Fick's First Law}

With the use of Fick's First Law of diffusion, the theoretical porewater As flux was calculated for the sediment cores from Lower Martin Lake (Figure 3.6). The predicted flux based on the theoretical temperature effects were relatively small for both cores, and the observed flux for each core had little to no change by the end of the experiment. This is because the sediments remained well oxygenated and did not allow for the change in redox state at the sediment boundary, which is an important mechanism in controlling the porewater flux (Palmer et al., 2019). Therefore, core 1 and core 2 did not have an overall increase in As porewater flux with warmer temperatures as hypothesized. Fick's Law calculations and measurements of change in As concentration of overlying water are two different ways to estimate As flux. Overall, both methods provided similar estimates of As flux, which provide support to the validity of the experimental results.

The predicted increase of As flux based on Fick's Law over the temperature range of 7$22^{\circ} \mathrm{C}$ was relatively low in core 1 as the range was 220.75 to $335.48 \mu \mathrm{g} / \mathrm{m}^{2} /$ day and in core 2 it was 11.44 to $17.38 \mu \mathrm{g} / \mathrm{m}^{2} /$ day. However, this increase is relatively small compared to with the $\sim 65$ $-5000 \mu \mathrm{g} / \mathrm{m}^{2} /$ day range of As fluxes from sediments reported in the literature (Andrade et al., 2010; Schuh et al., 2019; Van Den Berghe et al., 2017). The Fick's Law prediction only assumes an effect of temperature on diffusion, not a change in redox conditions or altered adsorption on $\mathrm{Fe}$ 
oxyhydroxides. This is consistent with the experimental design of keeping the sediments well aerated and under oxic conditions throughout the temperature treatments.

\subsubsection{Implications of Climate Change}

The general implications for long-term monitoring of contaminated lakes in the Yellowknife region under a warming climate is that in addition to monitoring temperature, temperaturemediated effects on sediment and water dissolved oxygen concentrations should be monitored. Increased primary production in subarctic lakes experiencing climate warming could also alter dissolved oxygen concentrations by stimulation of microbial metabolism within the lake's sediments. Sediments archive climate signals and allow paleolimnologists to identify past changes that occurred over a millennia ago (Williamson et al., 2009a). Lakes are considered hotspots for carbon cycling within their landscape, and lakes act as regulators for climate change, terrestrial and atmosphere change as well as aquatic carbon (Williamson et al., 2019a). Climate change is impacting aquatic ecosystems in many ways (Polunin, 2008). Arctic and subarctic lakes are also facing a large amount of environmental change due climate warming. Lakes function as a network of environmental sensors, that can be used as information on how climate change will affect water resources, and inland lakes have already shown the impact climate change will have on surrounding ecosystems (Vincent 2009; Williamson et al., 2009b). Some changes brought on by climate change in lakes and rivers of the northern hemisphere include a decrease in ice cover; the ice cover is on average 12 days shorter over the last 100 years (Magnuson et al., 2000). Any changes in ice cover can alter the positive feedback effects of warming on the lakes, which can increase the biological activity within the lakes (Quayle et al., 2002; Smol \& Doughlas 2007a; Ruhland et al., 2008; Antoniades et al., 2009) Climate change will also alter the amount of 
precipitation within the Arctic. Other components that will change with the climate is the ultraviolet radiation (UVR) exposure and an increase of $\mathrm{CO}_{2}$ in the atmosphere (Sobrino et al., 2009), and nitrogen deposition (Hessen et al., 2009) and a change within the food-web dynamics (Manca \& DeMott, 2009). Lakes are typically the lowest point within the landscape which receives input from the surrounding environment. Precipitation patterns, changes in seasonal temperature, and carbon flux within lakes all have an impact on the global biogeochemical cycles within aquatic and terrestrials' ecosystems (Williamson, et al., 2009a). For examples, changes in dissolved OM have changed in multiple lakes around the world, however the reason for the changes are not consistent amongst the study sites (Evan et al., 2006; Monteith et al., 2007). A larger amount of organic carbon is deposited in lakes than into the world's ocean sediments (Dean \& Gorham 1998), and rates of deposition of fixed organic carbon is much higher for lakes and reservoirs than in the world's oceans (Williamson 2009a). Hence, lakes function as a sink for organic carbon and greenhouse gases and regulate the impact of global climate change (Cole et al., 2007). It has been suggested to understand the impact on lakes from climate change would require the monitoring of key variables such as ice cover, and dissolved OM (Williamson, 2009b; Mueller et al., 2009; Kutser et al., 2005). Predictive climate models have suggested that increase in warming stability and decrease in lake water mixing will lead to oxygen depletion and the development of anoxic areas (MacIntyre et al., 2009; Verburg \& Hecky, 2009). Anoxia leads to regeneration of limiting nutrients, in some cases its phosphorus which leads to cyanobacteria blooms (Lopez-Urrutia, 2008; Wagner \& Adrian 2009), and can also lead to an increase in As flux in contaminated sediments. 


\subsection{Conclusion}

The results of this study indicate that temperature had a negligible direct impact on the flux of As from organic-rich and organic-poor sediments contaminated with As under oxidizing conditions. Previously reported effects of temperature on sediment As fluxes in other studies were likely due to indirect effects of temperature on biological oxygen demand and dissolved oxygen/redox conditions in the sediment surface layer which impact As compound desorption and adsorption rates. Future research should examine how climate-mediated changes to sediment biological oxygen demand and enhanced carbon cycling may impact As mobility in contaminated subarctic lakes. 


\section{GENERAL CONCLUSION}

The findings of this study were different then what was predicted. This study helps in understanding the importance of monitoring temperature impacts on different factors such as biological activity, oxygen levels within lakes, and that temperature alone had negligible influence on the mobility of As contamination within the Yellowknife Bay and Lower Martin Lake sediments. This study also highlights that in addition to temperature, dissolved oxygen levels should be monitored in the lakes since it has a potentially large impact on As mobility. Monitoring both temperature and oxygen levels of the lakes will help researchers properly model and predict the impact climate change on the Arctic and Subarctic lakes. The oxygen levels and temperature in both Yellowknife Bay and Lower Martin Lake should especially be monitored considering the history of impacts As has had on the local communities at Yellowknife, and the possible impact it can have in the future with increasing temperatures brought on by climate change. With the progression of the Giant Mine remediation project, it is important for planners to understand the possible impact historical contaminants can have on the community.

Other measurements that should be considered for future work include the speciation of As with increasing temperature, to understand how As speciation changes with temperature. This could include both inorganic As speciation and the possible production of organic As in sediments. By studying this, it will be possible to better possible changes to toxicity of As within the Yellowknife area lakes.

Another suggested study would be the one originally planned for this thesis before alterations had to be made due to Covid-19. It is still strongly suggested that a study should be conducted to 
assess the impact warmer temperatures, caused by climate change, will have on the bioaccumulation of the legacy As contamination on the biota of Great Slave Lake and a nearby smaller organic rich sediment rich lake. This project would characterize how legacy As contamination in sediment bioaccumulates in aquatic food chains, using an aquatic invertebrate as a bioindicator. By understanding what environmental conditions impact the bioaccumulation of As at the base of the food chain, we can predict how bioaccumulation will be influenced by the environmental changes brought on by climate change.

More specifically more research should be conducted examining the following aspects of As bioaccumulation. The first objective would be to determine which forms of As (inorganic and organic species) amphipods are exposed to from contaminated sediment. By understanding which As species exposure to amphipods, it can help in understanding the risks and possible toxicity to amphipods. The second aspect that should be studied is the species of As that bioaccumulate in amphipods. Depending on the species of As that are bioaccumulated in the amphipods determines the risks of toxicity the amphipods are facing. The third aspect will be to see if the As bioaccumulating in amphipods comes from the water or the sediments. By differentiating the source of As that can be bioaccumulate in amphipods will pin point the As sources that will require more monitoring to prevent the risk of As moving up the food web. The final aspect that should be further examined is if water temperature can influence the speciation or extent of As bioaccumulation in amphipods. If temperature can influence both the speciation and bioaccumulation of As in amphipods then warmer temperatures brought on by climate change may be more hazardous to the northern food web then initially understood. 
With climate change increasing the temperature within the Arctic and subarctic, the fate of the legacy mine contaminants is of high interest to researchers and those living within the surrounding area. These future studies will help researchers and the local community that use these lakes for recreational and subsistence activities, and to plan mitigation tactics of legacy contaminants. 


\section{REFERENCES}

Ahmann, D., Roberts, A.L., Krumholz, L.R., \& Morel, F.M. (1994). Microbe grows by reducing arsenic. Nature (London). 371(6500), 750-750. https://doi.org/10.1038/371750a0

Andrade, C.F., Jamieson, H.E., Kyser, T.K., Praharaj, T., \& Fortin, D. (2010). Biogeochemical redoxc cycling of arsenic in mine-impacted lake sediments and co-existing pore waters near Giant Mine, Yellowknife Bay, Canada. Appl. Geochem. 25, 199-211.

https://doi.org/10.1016/j.apgeochem.2009.11.005.

Antoniades, D., Veillette, J., Martineau, M., Belzile, C., Tomkins, J., Pienitz, R., Lamoureux, S., \& Vincent, W. (2009). Bacterial dominance of phototrophic communities in a High Arctic lake and its implications for paleoclimate analysis. Polar Science, 3(3), 147-161. https://doi.org/10.1016/j.polar.2009.05.002

Aposhian, H. V., \& Aposhian, M. M. (2006). Arsenic toxicology: five questions. Chemical Research in Toxicology, 19(1), 1-15. https://doi.org/10.1021/tx050106d

Appelo, C. A. J., Van der Weiden, M. J. J., Tournassat, C., \& Charlet, L. (2002). Surface complexation of ferrous iron and carbonate on ferrihydrite and the mobilization of arsenic. Environ. Sci. Technol. 36 (14), 3096-3103. https://doi.org/10.1021/es010130n

Azcue, J. M., Nriagu, J. O., \& Schiff, S. (1994). Role of sediment porewater in the cycling of arsenic in a mine-polluted lake. Environment International. 20(4), 517-527. https://doi.org/10.1016/0160-4120(94)90200-3

Barrett, P. M., Hull, E. A., Burkart, K., Hargrave, O., McLean, J., Taylor, V. F., Jackson, B. P., Gawel, J. E., \& Neumann, R. B. (2019). Contrasting arsenic cycling in strongly and weakly stratified contaminated lakes: Evidence for temperature control on sediment-water arsenic fluxes. Limnology and Oceanography, 64(3), 1333-1346. https://doi.org/10.1002/lno.11119

Bauer, M., \& Blodau, C. (2006). Mobilization of arsenic by dissolved organic matter from iron oxides, soils and sediments. Sci. Total Environ. 354, 179-190.

https://doi.org/10.1016/j.scitotenv.2005.01.027

Bennett, W. W., Teasdale, P. R., Panther, J. G., Welsh, D. T., Zhao, H., \& Jolley, D. F. (2012). Investigating arsenic speciation and mobilization in sediments with DGT and DET: A mesocosm evaluation of oxic-anoxic transitions. Environmental Science and Technology, 46(7), 39813989. https://doi.org/10.1021/es204484k

Bissen, M., \& Frimmel, F. (2003a). Arsenic - a Review. Part I: occurrence, toxicity, speciation, mobility. Acta Hydrochimica et Hydrobiologica. 31(1), 9-18.

https://doi.org/10.1002/aheh.200390025 
Bissen, M., \& Frimmel, F. (2003b). Arsenic - a Review. Part II: oxidation of arsenic and its removal in water treatment. Acta Hydrochimica et Hydrobiologica. 31(2), 97-107.

https://doi.org/10.1002/aheh.200300485

Bonte, M., van Breukelen, B. M., \& Stuyfzand, P. J. (2013). Temperature-induced impacts on groundwater quality and arsenic mobility in anoxic aquifer sediments used for both drinking water and shallow geothermal energy production. Water Research. 47, 5088-5100. https://doi.org/10.1016/j.watres.2013.05.049

Borch, T., Kretzschmar, R., Kappler, A., Cappellen, P. V., Ginder-Vogel, M., Voegelin, A., \& Campbell, K. (2010). Biogeochemical redox processes and their impact on contaminant dynamics. Environmental Science and Technology. 44(1), 15-23.

https://doi.org/10.1021/es9026248

Bowell, R.J., Alpers, C.N., Jamieson, H.E., Nordstrom, D.K., \& Majzlan, J. (2014). The environmental geochemistry of arsenic- an overview. Rev. Mineral. Geochem. 79, 1-16. https://doi.org/10.2138/rmg.2014.79.1

Boyle, R.W. (1960). The geology, geochemistry, and origin of gold deposits of the Yellowknife District. Geol. Surv. Can. Mem. 310.

Boyle D., Brix K.V., Amlund, H., Lundebye, A.K., Hogstrand, C., \& Bury, N.R. (2008) Natural arsenic contaminated diets perturb reproduction in fish. Environmental Science and Technology. 2008; 42(14):5354-60. https://doi.org/10.1021/es800230w

Bradley, R.S., Vuille, M., Diaz, H.F., \& Vergara, W. (2006). Climate Change. Threats to water supplies in the tropical Andes. Science (American Association for the Advancement of Science), 312(5781), 1755-1756. https://doi.org/10.1126/science.1128087

Bromstad, M.J., Wrye, L.A., \& Jamieson, H.E. (2017). The characterization, mobility, and persistence of roaster-derived arsenic in soils at Giant Mine, NWT. Appl. Geochem. 82, 102-118. https://doi.org/10.1016/j.apgeochem.2017.04.004.

Burke, V., Greskowiak, J., Asmuß, T., Bremermann, R., Taute, T., \& Massmann, G. (2014). Temperature dependent redox zonation and attenuation of wastewater-derived organic micropollutants in the hyporheic zone. Science of the Total Environment. 482-483, 53-61. https://doi.org/10.1016/j.scitotenv.2014.02.098

Canadian Hydrographic Service (CHS). (2005). Cartographer Canadian Hydrographic Service Chart 6369-Yellowknife Bay: Fisheries and Oceans Canada.

CCME, 2021. Canadian sediment quality guidelines for the protection of aquatic life: Arsenic; In: Canadian Council of Ministers of the Environment (CCME), editor. Canadian environmental quality guidelines, Winnipeg. [2021| Visited 29-06-2021] https://ccme.ca/en/results/9/ch/1,2,3,4,5 
Chételat, J., Amyot, M., Muir, D., Black, J., Richardson, M., Evans, M., \& Palmer, M. (2017). Arsenic, antimony, and metal concentrations in water and sediment of Yellowknife Bay; Northwest Territories Geological Survey Open File 2017-05.

Chételat, J., Amyot, M., Muir, D., Black, J., Richardson, M., Evans, M., and Palmer, M., 2018. Arsenic, antimony, and metal concentrations in water and sediment of Yellowknife Bay; Northwest Territories Geological Survey, NWT Open File 2017-05. 40 pages and appendices.

Chételat, J., Cott, P. A., Rosabal, M., Houben, A., McClelland, C., Rose, E. B., \& Amyot, M. (2019). Arsenic bioaccumulation in subarctic fishes of a mine-impacted bay on Great Slave Lake, Northwest Territories, Canada. PLoS ONE. 14(8), 1-23.

https://doi.org/10.1371/journal.pone.0221361

Coker, V. S., Gault, A. G., Pearce, C. I., van der Laan, G.,Telling, N. D., Charnock, J. M., Polya, D. A., \& Lloyd, J. R. (2006). XAS and XMCD evidence for species-dependent partitioning of arsenic during microbial reduction of ferrihydrite to magnetite. Environ. Sci. Technol. 40, 77457750. https://doi.org/10.1021/es060990+

Cohen, A.S. (2003). Paleolimnology: the history and evolution of lake systems. Oxyford Univ. Press.

Cole, J.J.,. Prairie, Y. T, Caraco, N. F., McDowell, W. H., Tranvik, L. J., Striegl, R. G., Duarte, C. M., Kortelainen, P.,. Downing, J. A, Middelburg, J. J., \& Melack, J. (2007). Plumbing the global carbon cycle: integrating inland waters into the terrestrial carbon budget. Ecosystems (New York), 10(1), 171-184. https://doi.org/10.1007/s10021-006-9013-8

Craw, D., \& Bowell, R.J. (2014). The characterization of arsenic in mine waste. Rev. Mineral. Geochem. 79, 473-505. https://doi.org/10.2138/rmg.2014.79.10

Danczak, R. E., Sawyer, A. H., Williams, K. H., Stegen, J. C., Hobson, C., \& Wilkins, M. J. (2016). Seasonal hyporheic dynamics control coupled microbiology and geochemistry in Colorado River sediments. Journal of Geophysical Research: Biogeosciences. 121, 2976-2987. https://doi.org/10.1002/2016JG003527

Dean, W. E., \& Gorham, E. (1998). Magnitude and significance of carbon burial in lakes, reservoirs, and peatlands. Geology. 26, 535-538. https://doi.org/10.1130/00917613(1998)026<0535:MASOCB $>2.3 . \mathrm{CO} ; 2$

De Villiers, A.J., \& Baker, P.M. (1970). An investigation of the health status of inhabitants of Yellowknife, Northwest Territories. Ottawa: Canada Department of Health and Welfare. LAC RG 29(2977). File 851-5-2, page 4.

Dixit, S., \& Hering, J. G. (2003). Comparison of arsenic(V) and arsenic(III) sorption onto iron oxide minerals: Implications for arsenic mobility. Environ. Sci. Technol. 37, 4182-4189. https://doi.org/10.1021/es030309t 
Dopp, E., Von Recklinghausen, U., Diaz-Bone, R., Hirner, A., \& Rettenmeier, A. (2010). Cellular uptake, subcellular distribution and toxicity of arsenic compounds in methylating and nonmethylating cells. Environmental Research, 110(5), 435-442. https://doi.org/10.1016/j.envres.2009.08.012

Du Laing, G., Chapagain, S.K., Dewispelaere, M., Meers, E., Kazama, F., Tack, F.M.G., Rinklebe, J., \& Verloo, M.G. (2009). Presence and mobility of arsenic in estuarine wetland soils of the Scheldt estuary (Belgium). J. Environ. Monit. 11, 873-881. https://doi.org/10.1039/b815875d

Duncan, E. G., Maher, W. A., \& Foster, S. D. (2015). Contribution of arsenic species in unicellular algae to the cycling of arsenic in marine ecosystems. Environmental Science and Technology, 49(1), 33-50. https://doi.org/10.1021/es504074z

Electro Analytical Instruments (EAI). ElectroAnalytical electrodes and sensors. EA Instruments Ltd. London, UK. [01-2017|18-08-2021].

http://www.eainstruments.com/Products/Sensors/Sensors.htm

Environment and Climate Change Canada (ECCC). (2018). 1981-2010 Climate Normals \& Averages. Yellowknife. Available from: http://climate.weather.gc.ca/climate normals/.

Erickson, R., Mount, D., Highland, T., Hockett, J., Leonard, E., Mattson, V., Dawson, T., \& Lott, K. (2010). Effects of copper, cadmium, lead, and arsenic in a live diet on juvenile fish growth. Canadian Journal of Fisheries and Aquatic Sciences. 67(11), 1816-1826. https://doi.org/10.1139/F10-098

European Virtual Institute of Speciation Analysis (EVISA). (2003). PACS-2 - Marine Sediment Reference Materials for Trace Metals and other Constituents. European Network, European Virtual Institute of Speciation Analysis (EVISA). Retrieved May 11th, 2021. http://www.speciation.net/Database/Materials/National-Research-Council-of-Canada-NRC--

CNRC/PACS2--Marine-Sediment-Reference-Materials-for-Trace-Metals-and-otherConstituents-;i45

Evans, C., Chapman, P., Clark, J., Monteith, D., \& Cresser, M. (2006). Alternative explanations for rising dissolved organic carbon export from organic soils. Global Change Biology, 12(11), 2044-2053. https://doi.org/10.1111/j.1365-2486.2006.01241.x

Fawcett, S.E., Jamieson, H.E., Nordstrom, D.K., \& McCleskey, R.B. (2015). Arsenic and antimony geochemistry of mine wastes, associated waters and sediments at the Giant Mine, Yellowknife, Northwest Territories, Canada. Appl. Geochem 62, 3-17.

https://doi.org/10.1016/j.apgeochem.2014.12.012.

Fernandez, P.G., Linge, H.G., \& Willing, M.J. (1996). Oxidation of arsenopyrite (FeAsS) in acid part II: stoichiometry and reaction scheme. J. Appl. Electrochem. 26, 585-591. https://doi.org/10.1007/BF00253456 
Galloway, J.M., Palmer, M., Jamieson, H.E. Patterson, R.T., Nasser, N., Falck, H., Macumber, A.L., Goldsmith, S.A., Sanei, H., Nomandeau, P., Hadlari, T., Roe, H.M., Neville, L.A., \& Lamay, D. (2015). Geochemsitry of lakes across ecozones in the Northwest Territories and implications for the distribution of arsenic in the Yellowknife Region. Part 1: Sediments; Geological Survey of Canada. (Open File 7908, 50 p.). https://doi.org/10.4095/296954

Galloway, J., Swindles, G., Jamieson, H., Palmer, M., Parsons, M., Sanei, H., Macumber, A., Timothy Patterson, R., \& Falck, H. (2018). Organic matter control on the distribution of arsenic in lake sediments impacted by $\sim 65$ years of gold ore processing in subarctic Canada. The Science of the Total Environment. 622-623, 1668-1679. https://doi.org/10.1016/j.scitotenv.2017.10.048

Gao, Y., \& Mucci, A. (2001). Acid base reactions, phosphate and arsenate complexation, and their competitive adsorption at the surface of goethite in $0.7 \mathrm{M} \mathrm{NaCl}$ solution. Geochimica et Cosmochimica Acta. 65(14), 2361-2378. https://doi.org/10.1016/S0016-7037(01)00589-0

Government of Canada; Indigenous and Northern Affairs Canada; Communications Branch. (2018, April 13). History of giant mine. Retrieved April 11, 2021, from https://www.aadncaandc.gc.ca/eng/1100100027388/1100100027390

Groves, D.J., Goldfarb, R.J., Gebre-Mariam, M., Hagemann, S.G., \& Robert, F. (1998). Orogenic gold deposits: a proposed classification in the context of their crustal distribution and relationship to other gold deposit types. Ore Geol. Rev. 13, 7-27. https://doi.org/10.1016/S0169$\underline{1368(97) 00012-7}$

Gurung, J.K., Ishiga, H., \& Khadka, M.S., (2005). Geological and geochemical examination of arsenic contamination in groundwater in the Holocene Terai Basin, Nepal. Environ. Geol. 49, 98113. https://doi.org/10.1007/s00254-005-0063-6

Health Canada (2020). Guidelines for Canadian Drinking Water Quality-Summary Table. Water and Air Quality Bureau, Healthy Environments and Consumer Safety Branch, Health Canada, Ottawa, Ontario. [04-09-2020| 08-04-2021]. https:/www.canada.ca/en/healthcanada/services/environmental-workplace-health/reports-publications/water-quality/guidelinescanadian-drinking-water-quality-summary-table.html

Hejzlar, J., Dubrovský, M., Buchtele, J., \& Růžička, M. (2003). The apparent and potential effects of climate change on the inferred concentration of dissolved organic matter in a temperate stream (the Malše River, South Bohemia). Science of the Total Environment. 310(1-3), 143-152. https://doi.org/10.1016/S0048-9697(02)00634-4

Hellweger, F., \& Lall, U. (2004). Modeling the effect of algal dynamics on arsenic speciation in lake biwa. Environmental Science \& Technology. 38(24), 6716-6723. https://doi.org/10.1021/es049660k

Henzler, A. F., Greskowiak, J., \& Massmann, G. (2016). Seasonality of temperatures and redox zonations during bank filtration-A modeling approach. Journal of Hydrology. 535, 282-292. https://doi.org/10.1016/j.jhydrol.2016.01.044 
Hessen, D.O., Andersen, T., Larsen, S., Skjelkvåle, B.L., \& De Wit., H.A. (2009). Nitrogen deposition, catchment productivity, and climate as determinants of lake stoichiometry. Limnology and Oceanography. 54(6), 2520-2528. https://doi.org/10.4319/10.2009.54.6_part_2.2520

Horn, H., Paul, L., Horn, W., Uhlmann, D., \& Röske, I. (2015). Climate change impeded the reoligotrophication of the Saidenbach Reservoir. International Review of Hydrobiology. 100(2), 43-60. https://doi.org/10.1002/iroh.201401743

Hubbard, L., Marshall, D.D., Anglin, C.D., Thorkelson, D., \& Robinson, M.H. (2006). Giant Mine: alteration, mineralization, and ore-structures with an emphasis on the supercrest zone. In: Anglin, C.D., Falck, H.,Wright, D.F., Ambrose, E.J. (Eds.), Gold in the Yellowknife Greenstone Belt, Northwest Territories: Results of the EXTECH III Multidisciplinary Research Project. Geological Association of Canada, Mineral Deposits Division. 197-212.

Hughes, M.F. (2002). Arsenic toxicity and potential mechanisms of action. Toxicology Letters, v. 133, 1-16.

Jackson, B., \& Miller, W. (1999). Soluble arsenic and selenium species in fly ash/organic wasteamended soils using ion chromatography-inductively coupled plasma mass spectrometry. Environmental Science \& Technology. 33(2), 270-275. https://doi.org/10.1021/es980409c

Jain, A., \& Loeppert, R. H. (2000). Effect of Competing Anions on the Adsorption of Arsenate and Arsenite by Ferrihydrite. Journal of Environmental Quality. 29(5), 1422-1430.

https://doi.org/10.2134/jeq2000.00472425002900050008x

Johnston, S. G., Bennett, W. W., Doriean, N., Hockmann, K., Karimian, N., \& Burton, E. D. (2020). Antimony and arsenic speciation, redox-cycling and contrasting mobility in aminingimpacted river system. Science of the Total Environment. 710, 136354.

https://doi.org/10.1016/j.scitotenv.2019.136354

Johnston, S. G., Keene, A. F., Bush, R. T., Burton, E. D., Sullivan, L. A., Isaacson, L., et al. (2011). Iron geochemical zonation in a tidally inundated acid sulphate soil wetland. Chemical Geology. 280(3-4), 257-270. https://doi.org/10.1016/j.chemgeo.2010.11.014

Johnston, S. G., Karimian, N., \& Burton, E. D. (2020). Seasonal Temperature Oscillations Drive Contrasting Arsenic and Antimony Mobilization in a Mining-Impacted River System. Water Resources Research. 56(10), 1-20. https://doi.org/10.1029/2020WR028196

Kalbitz, K., \& R. Wennrich. (1998). Mobilization of heavy metals and arsenic in polluted wetland soils and its dependence on dissolved organic matter. Sci. Total Environ. 209(1), 27-39. https://doi.org/10.1016/S0048-9697(97)00302-1

Kalff, J. (2001) Limnology. Prentice Hall. Upper Saddle River, N.J., USA. 
Kerr, D.E. (2006). Surficial geology and exploration geochemistry, Yellowknife area. In: Anglin, C.D., Falck, H., Ambrose, E.J. (Eds.), Gold in the Yellowknife Greenstone Belt, Northwest Territories: Results of the EXTECH III Multidisciplinary Research Project. Geological Association of Canada, Mineral Deposits Division. 301-324.

Kersten, M., \& Vlasova, N. (2009). Arsenite adsorption on goethite at elevated temperatures. Applied Geochemistry. 24(1), 32-43. https://doi.org/10.1016/j.apgeochem.2008.10.004

Kocar, B. D., \& Fendorf, S. (2009). Thermodynamic constraints on reductive reactions influencing the biogeochemistry of arsenic in soils and sediments. Environmental Science \& Technology. 43(13), 4871-4877. https://doi.org/10.1021/es8035384

Kocar, B. D., Herbel, M. J., Tufano, K. J., \& Fendorf, S. (2006). Contrasting effects of dissimilatory iron(III) and arsenic(V) reduction on arsenic retention and transport. Environ. Sci. Technol. 40(21), 6715-6721. https://doi.org/10.1021/es061540k

Kossoff, D., Hudson-Edwards, K.A., Dubbin, W.E., Alfredsson, M., \& Geraki, T. (2012). Cycling of $\mathrm{As}, \mathrm{Pb}, \mathrm{Pb}$ and $\mathrm{Sb}$ during weatheirng of mine tailings: implications for fluvial environments. Miner. Mag. 76(5), 1209-1228. https://doi.org/10.1180/minmag.2012.076.5.14

Kraemer, B., Anneville, O., Chandra, S., Dix, M., Kuusisto, E., Livingstone, D., Rimmer, A., Schladow, S., Silow, E., Sitoki, L., Tamatamah, R., Vadeboncoeur, Y., \& McIntyre, P. (2015). Morphometry and average temperature affect lake stratification responses to climate change. Geophysical Research Letters. 42(12), 4981-4988. https://doi.org/10.1002/2015GL064097

Kutser, T., Pierson, D.C., Tranvik, L., Reinart, A., Sobek, S., \& Kallio, K. (2005). Using satellite remote sensing to estimate the colored dissolved organic matter absorption coefficient in lakes. Ecosystems (New York). 8(6), 709-720. https://doi.org/10.1007/s10021-003-0148-6

La Force,M.J., Hansel, C.M., Fendorf, S.. (2000). Arsenic speciation, seasonal transformations, and co-distribution with iron in a mine waste-influenced palustrine emergent wetland. Environ. Sci. Technol. 34(18), 3937-3943. https://doi.org/10.1021/es0010150

Lavery, P. S., Oldham, C. E., \& Ghisalberti, M. (2001). The use of fick's first law for predicting porewater nutrient fluxes under diffusive conditions. Hydrological Processes. 15(13), 2435-2451. https://doi.org/10.1002/hyp.297

Levy, J., Stauber, J., Adams, M., Maher, W., Kirby, J., \& Jolley, D. (2005). Toxicity, biotransformation, and mode of action of arsenic in two freshwater microalgae (Chlorella sp. and Monoraphidium arcuatum. Environmental Toxicology and Chemistry, 24(10), 2630-2639. https://doi.org/10.1897/04-580R.1

Li, W., Liu, J., \& Hudson-Edwards, K. A. (2020). Seasonal variations in arsenic mobility and bacterial diversity: The case study of Huangshui Creek, Shimen Realgar Mine, Hunan Province, China. Science of the Total Environment, 749, 142353.

https://doi.org/10.1016/j.scitotenv.2020.142353. 
Lloyd, J. R., \& Oremland, R. S. (2006). Microbial transformations of arsenic in the environment: From soda lakes to aquifers. Elements. 2(2), 85-90. https://doi.org/10.2113/gselements.2.2.85

López-Urrutia, A. (2008). The metabolic theory of ecology and algal bloom formation. Limnology and oceanography. 53(5), 2046-2047. https://doi.org/10.4319/lo.2008.53.5.2046

Lopez, A. R., Hesterberg, D. R., Funk, D. H., \& Buchwalter, D. B. (2016). Bioaccumulation Dynamics of Arsenate at the Base of Aquatic Food Webs. Environmental Science and Technology, 50(12), 6556-6564. https://doi.org/10.1021/acs.est.6b01453

Lovley, D. R., Coates, J.D., Blunt-Harris, E.L., Phillips, E.J.P. \& Woodward, J.C. (1996). Humic substances as electron acceptors for microbial respiration. Nature. 382, 445-448.

https://doi.org/10.1038/382445a0

Lüders, K., Dahmke, A., Fiedler, M., \& Köber, R. (2020). Temperature influence on mobilisation and (re)fixation of trace elements and heavy metals in column tests with aquifer sediments from 10 to $70^{\circ} \mathrm{C}$. Water Research. 169, 115266.

https://doi.org/10.1016/j.watres.2019.115266

Lyons, W.C. (2010). Lear more about formation resistivity factor basic principles, definitions and data. Working Guide to Reservoir Engineering.

Ma, W., Huang, T., Li, X., Zhang, H., \& Ju, T. (2015). Impact of short-term climate variation and hydrology change on thermal structure and water quality of a canyon-shaped, stratified reservoir. Environmental Science and Pollution Research International. 22(23), 18372-18380. https://doi.org/10.1007/s11356-015-4764-4

MacDonald, R., Harner, T., Fyfe, J. (2005). Recent climate change in the Arctic and its impact on contaminant pathways and interpretation of temporal trend data. Sci. Total Environ. 342(1), 5-86. https://doi.org/10.1016/j.scitotenv.2004.12.059

MacIntyre, S., Fram J. P., Kushner, P. J., Bettez, N. B., O’Brien, W. J., Hobbie, J. E. \& Kling, G.W. (2009). Climate-related variations in mixing dynamics in an Alaskan Arctic lake.

Limnology and Oceanography. 54(6), 2401-2417.

https://doi.org/10.4319/1o.2009.54.6 part 2.2401

Mackay, A.A., Gan, P., Yu, R., \& Smets, B.F. (2014). Seasonal arsenic accumulation in stream sediments at a groundwater discharge zone. Environ. Sci. Technol. 48(2), 920-929.

https://doi.org/10.1021/es402552u

Manca, M., \& DeMott, W.R. (2009). Response of the invertebrate predator Bythotrephes to a climate-linked increase in the duration of a refuge from fish predation. Limnology and Oceanography. 54(6), 2506-2512. https://doi.org/10.4319/10.2009.54.6_part 2.2506 
Mann, P., Sobczak, W., LaRue, M., Bulygina, E., Davydova, A., Vonk, J., Schade, J., Davydov, S., Zimov, N., Holmes, R., \& Spencer, R. (2014). Evidence for key enzymatic controls on metabolism of Arctic river organic matter. Global Change Biology. 20(4), 1089-1100. https://doi.org/10.1111/gcb.12416

Martin, A. J., \& Pedersen, T. F. (2004). Alteration to lake trophic status as a means to control arsenic mobility in a mine-impacted lake. Water Research, 38(20), 4415-4423. https://doi.org/10.1016/j.watres.2004.08.025

Mass, M., Tennant, A., Roop, B., Cullen, W., Styblo, M., Thomas, D., Kligerman, A.D., \& Mass, M. (2001). Methylated trivalent arsenic species are genotoxic. Chemical Research in Toxicology. 14(4), 355-361. https://doi.org/10.1021/tx0002511

Masscheleyn, P., \& Patrick, W. (1990). Speciation and redox chemistry of selenium and arsenic in wetland soils and sediments (ProQuest Dissertations Publishing).

Meier, J., Costa, R., Smalla, K., Boehrer, B., \& Wendt-Potthoff, K. (2005). Temperature dependence of $\mathrm{Fe}(\mathrm{III})$ and sulphate reduction rates and its effect on growth and composition of bacterial enrichments from an acidic pit lake neutralization experiment. Geobiology. 3(4), 261274. https://doi.org/10.1111/j.1472-4669.2006.00065.x

Mladenov, N., Zheng, Y., Miller, M. P., Nemergut, D. R., Legg, T., Simone, B., Hageman, C., Rahman, M. M., Ahmed, K. M., \& McKnight, D. M. (2010). Dissolved organic matter sources and consequences for iron and arsenic mobilization in bangladesh aquifers. Environmental Science \& Technology. 44(1), 123-128. https://doi.org/10.1021/es901472g

Moir, I., Falck, H., Hausser, R.L., \& Robb, M. (2006). The history of mining and its impact on the development of Yellowknife; in Gold in the Yellowknife Greenstone Belt, Northwest Territories: Results of the EXTECH III Multidisciplinary Research Project, edited by C.D. Anglin, H. Falck, D.F. Wright and E.J. Ambrose; Geological Association of Canada, Mineral Deposits Division, Special Publication. 3, 11-28.

Monteith, D., Stoddard, J., Evans, C. De Wit, H.A., Forsius, M., Høgåsen, T., Wilander, A., Skjelkvåle, B.L., Jeffries. D.S., Vuorenmaa, J., Keller, B., Kopácek, J., \& Vesely, J. (2007). Dissolved organic carbon trends resulting from changes in atmospheric deposition chemistry. Nature. 450, 537-540 https://doi.org/10.1038/nature06316

Mueller, D.R., Van Hove, P., Antoniades, D., Jeffries M.O., \& Vincent, W.F. (2009). High Arctic lakes as sentinel ecosystems: cascading regime shifts in climate, ice cover, and mixing. Limnology and Oceanography. 54(6), 2371-2385.

https://doi.org/10.4319/1o.2009.54.6 part 2.2371

Neff, J., \& Neff, J. (1997). Ecotoxicology of arsenic in the marine environment. Environmental Toxicology and Chemistry. 16(5), 917-927. https://doi.org/10.1002/etc.5620160511 
$\mathrm{Ng}$, Jack C. (2005). Environmental contamination of arsenic and its toxicological impact on humans. Environmental Chemistry. 2(3), 146-60. https://doi.org/10.1071/EN05062

O’Beirne, M., Werne, J., Hecky, R., Johnson, T., Katsev, S., \& Reavie, E. (2017). Anthropogenic climate change has altered primary productivity in Lake Superior. Nature Communications. 8(1), 15713-15713. https://doi.org/10.1038/ncomms15713

Ona-Nguema, G., Morin, G., Wang, Y. H., Menguy, N., Juillot, F., Olivi, L., Aquilanti, G., Abdelmoula, M., Ruby, C., Bargar, J. R., Guyot, F., Calas, G., \& Brown, G. E. (2009). Arsenite sequestration at the surface of nano- $\mathrm{Fe}(\mathrm{OH})_{2}$, ferrous-carbonate hydroxide, and green-rust after bioreduction of arsenic-sorbed lepidocrocite by Shewanella putrefaciens. Geochim. Cosmochim. Acta. 73, 1359-1381.

http://www.sciencedirect.com.biblioplanets.gate.inist.fr/science/article/pii/S0016703708007370

OREAS. (2019). Certificate of analysis for gold oxide, certified reference material OREAS 262. ORE Research \& Exploration. Bayswater North, Australia. 1-12.

Oremland, R.S., \& Stolz, J.F. 2003). The Ecology of Arsenic. Science (Washington). 300(5621), 939-944. https://doi.org/10.1126/science.1081903

Pallud, C., Rhoades, C. C., Schneider, L., Dwivedi, P., \& Borch, T. (2020). Temperature-induced iron (III) reduction results in decreased dissolved organic carbon export in subalpine wetland soils, Colorado, USA. Geochimica et Cosmochimica Acta. 280, 148-160.

https://doi.org/10.1016/j.gca.2020.03.023

Palmer, M., Chételat, J., Richardson, M., Jamieson, H. E., \& Galloway, J. M. (2019). Seasonal variation of arsenic and antimony in surface waters of small subarctic lakes impacted by legacy mining pollution near Yellowknife, NT, Canada. Science of the Total Environment. 684, 326339. https://doi.org/10.1016/j.scitotenv.2019.05.258

Palmer, M. J., Chételat, J., Jamieson, H. E., Richardson, M., \& Amyot, M. (2021). Hydrologic control on winter dissolved oxygen mediates arsenic cycling in a small subarctic lake. Limnology and Oceanography. 66(S1), S30-S46. https://doi.org/10.1002/1no.11556

Palmer, M.J., Galloway, J.M., Jamieson, H.E., Patterson, R.T., Falck, H., \& Kokelji. (2016). The concentration of arsenic in lake waters of Yellowknife area. Northwest Territories Geological Survey, NWT Open File 2015-2016.

Pedlar, R.M., Ptashynski, M.D., Evans, R., \& Klaverkamp, J.F. (2002) Toxicological effects of dietary arsenic exposure in lake whitefish (Coregonus clupeaformis). Aquatic Toxicology. 57(3):167-89. https://doi.org/10.1016/S0166-445X(01)00198-9

Petrick, J., Ayala-Fierro, F., Cullen, W., Carter, D., \& Vasken Aposhian, H. (2000). Monomethylarsonous Acid (MMAIII) Is More Toxic Than Arsenite in Chang Human Hepatocytes. Toxicology and Applied Pharmacology, 163(2), 203-207. https://doi.org/10.1006/taap.1999.8872 
Polunin, N. (2008). Aquatic ecosystems: trends and global prospects. Cambridge University Press.

Prowse, T., Beltaos, S., Gardner, J., Gibson, J., Granger, R., Leconte, R., Peters, D., Pietroniro, A., Romolo, L., \& Toth, B. (2006). Climate Change, Flow Regulation and Land-Use Effects on the Hydrology of the Peace-Athabasca-Slave System; Findings from the Northern Rivers Ecosystem Initiative. Environmental Monitoring and Assessment. 113(1), 167-197. https://doi.org/10.1007/s10661-005-9080-x

Price, P. B., \& Sowers, T. (2004). Temperature dependence of metabolic rates for microbial growth, maintenance, and survival. Proceedings of the National Academy of Sciences of the United States of America. 101(13), 4631-4636. https://doi.org/10.1073/pnas.0400522101

Quayle, W.C., Peck, L.S., Peat, P., Ellis-Evans, J.C., \& Harrigan, P.R. (2002). Extreme responses to climate change in Antarctic lakes. Science (American Association for the Advancement of Science). 295(5555), 645-645. https://doi.org/10.1126/science.1064074

Raab, A., Wright, S., Jaspars, M., Meharg, A., \& Feldmann, J. (2007). Pentavalent arsenic can bind to biomolecules. Angewandte Chemie (International Ed.). 46(15), 2594-2597. https://doi.org/10.1002/anie.200604805

Rahman, A.M., Hasegawa, H., \& Peter Lim, R. (2012). Bioaccumulation, biotransformation and trophic transfer of arsenic in the aquatic food chain. Environmental Research. 116, 118-135. https://doi.org/10.1016/j.envres.2012.03.014

Rahman, M., \& Hassler, C. (2014). Is arsenic biotransformation a detoxification mechanism for microorganisms? Aquatic Toxicology, 146, 212-219.

https://doi.org/10.1016/j.aquatox.2013.11.009

Rautio, M., Dufresne, F., Laurion, I., Bonilla, S., Vincent, W.F., \& Christoffersen, K.S. (2011). Shallow freshwater ecosystems of the circumpolar arctic. Écoscience (Sainte-Foy). 18(3), 204222. https://doi.org/10.2980/18-3-3463

Rawson, D.S. (1951). Studies of the Fish of Great Slave Lake. Journal of the Fisheries Research Board of Canada. 8(4), 207-240. https://doi.org/10.1139/f50-014

Redman, A., Macalady, D., \& Ahmann, D. (2002). Natural Organic Matter Affects Arsenic Speciation and Sorption onto Hematite. Environmental Science \& Technology. 36(13), 28892896. https://doi.org/10.1021/es0112801

Rizosphere Research Product. (2021). Rhizons $2.5 \mathrm{~mm}$, the standard size Rhizons for pore water sampling. Netherlands, From Website: https://www.rhizosphere.com/rhizons 
Roberts, L. C., Hug, S. J., Ruettimann, T., Billah, M., Khan, A. W., \& Rahman, M. T. (2004). Arsenic removal with iron(II) and iron(III) waters with high silicate and phosphate concentrations. Environ. Sci. Technol. 38(1), 307-315. https://doi.org/10.1021/es0343205

Rouwane, A., Rabiet, M., Bourven, I., Grybos, M., Mallet, L., \& Guibaud, G. (2016). Role of microbial reducing activity in antimony and arsenic release from an unpolluted wetland soil: A lab scale study using sodium azide as a microbial inhibiting agent. Environmental Chemistry. 13(6), 945-954. https://doi.org/10.1071/EN16029

Royle, M., \& Hockley, D. (2007). Giant Mine Remediation Plan. Prepared by SRK Consulting, Engineering and Scientist, SENES Consultants Limited, and the Government of Canada. Prepared for Indian and Northern Affairs Canadian Giant Mine Remediation Project. 1-260.

Rühland, K., Paterson, A., \& Smol, J. (2008). Hemispheric-scale patterns of climate-related shifts in planktonic diatoms from North American and European lakes. Global Change Biology. 14(11), 2740-2754. https://doi.org/10.1111/j.1365-2486.2008.01670.x

Sanei, H., Stasiuk, L., \& Goodarzi, F. (2005). Petrological changes occurring in organic matter from Recent lacustrine sediments during thermal alteration by Rock-Eval pyrolysis. Organic Geochemistry. 36(8), 1190-1203. https://doi.org/10.1016/j.orggeochem.2005.02.009

Sandlos, J., \& Keeling, Arn. (2012). Giant Mine: historical summary. St. Johns, NL: Memorial University Department of Geography and Department of History.

https://reviewboard.ca/upload/project_document/EA0809001 Giant Mine History Summary.PDF

Schilling, K., Borch, T., Rhoades, C. C., \& Pallud, C. E. (2019). Temperature sensitivity of microbial Fe(III) reduction kinetics in subalpine wetland soils. Biogeochemistry. 142(1), 19-35. https://doi.org/10.1007/s10533-018-0520-4

Schuh, C.E., Jamieson, H.E., Palmer, M.J., \& Martin, A.J. (2018). Solid-phase speciation and postdepositional mobility of arsenic in lake sediments impacted by ore roasting at legacy gold mines in the Yellowknife area, Northwest Territories, Canada. Applied Geochemistry, 91(C), 208-220. https://doi.org/10.1016/j.apgeochem.2017.10.025

Schuh, C. E., Jamieson, H. E., Palmer, M. J., Martin, A. J., \& Blais, J. M. (2019). Controls governing the spatial distribution of sediment arsenic concentrations and solid-phase speciation in a lake impacted by legacy mining pollution. Science of the Total Environment, 654, 563-575. https://doi.org/10.1016/j.scitotenv.2018.11.065

Sharma, V., \& Sohn, M. (2009). Aquatic arsenic: toxicity, speciation, transformations, and remediation. Environment International. 35(4), 743-759.

https://doi.org/10.1016/j.envint.2009.01.005 
Schwarzenbach, R. P., Stierli, R., Lanz, K., \& Zeyer, J. (1990). Quinone and iron porphyrin mediated reduction of nitroaromatic compounds in homogeneous aqueous solution.

Environmental Science \& Technology. 24(10), 1566-1574. https://doi.org/10.1021/es00080a017

Simmler, M., Bommer, J., Frischknecht, S., Christl, I., Kotsev, T., \& Kretzschmar, R. (2017).

Reductive solubilization of arsenic in a mining-impacted river floodplain: Influence of soil properties and temperature. Environmental Pollution, 231(Pt 1), 722-731.

https://doi.org/10.1016/j.envpol.2017.08.054

Smedley, P., \& Kinniburgh, D. (2002). A review of the source, behaviour and distribution of arsenic in natural waters. Applied Geochemistry. 17(5), 517-568. https://doi.org/10.1016/S08832927(02)00018-5

Smith, A., Hopenhayn-Rich, C., Bates, M., Goeden, H., Hertz-Picciotto, I., Duggan, H., Wood, R., Kosnett, M., \& Smith, M. (1992). Cancer risks from arsenic in drinking water. Environmental Health Perspectives. 97, 259-267. https://doi.org/10.1289/ehp.9297259

Smol, J. (2008). Pollution of lakes and rivers a paleoenvironmental perspective (2nd ed.). Blackwell Pub.

Smol, J.P., \& Douglas, M.S.D. (2007). From controversy to consensus: making the case for recent climate change in the Arctic using lake sediments. Frontiers in Ecology and the Environment. 5(9), 466-474. https://doi.org/10.1890/060162

Sobrino, C., Neale, P. J., Phillips-Kress, J. D., Moeller, R. E., \& Porter, J. A. (2009). Elevated $\mathrm{CO}_{2}$ increases sensitivity to ultraviolet radiation in lacustrine phytoplankton assemblages.

Limnology and Oceanography. 54(6), 2448-2459.

https://doi.org/10.4319/10.2009.54.6 part_2.2448

Spence, C., Kokelj, S., Kokelj, S., McCluskie, M., \& Hedstrom, N. (2015). Evidence of a change in water chemistry in Canada's subarctic associated with enhanced winter streamflow. Journal of Geophysical Research. Biogeosciences. 120(1), 113-127. https://doi.org/10.1002/2014JG002809

Stachowicz, M., Hiemstra, T., \& van Riemsdijk, W. H. (2007). Arsenic-bicarbonate interaction on goethite particles. Environmental Science \& Technology. 41(16), 5620-5625.

https://doi.org/10.1021/es063087i

Stachowicz, M., Hiemstra, T., \& Van Riemsdijk, W. (2008). Multi-competitive interaction of $\mathrm{As}(\mathrm{III})$ and $\mathrm{As}(\mathrm{V})$ oxyanions with $\mathrm{Ca} 2+, \mathrm{Mg} 2+, \mathrm{PO} 3-4$, and $\mathrm{CO} 2-3$ ions on goethite. Journal of Colloid and Interface Science. 320(2), 400-414. https://doi.org/10.1016/j.jcis.2008.01.007

Stolz, J., \& Oremland, R. (1999). Bacterial respiration of arsenic and selenium. FEMS Microbiology Reviews. 23(5), 615-627. https://doi.org/10.1016/S0168-6445(99)00024-8 
Stroeve, J., Serreze, M., Drobot, S., Gearheard, S., Holland, M., Maslanik, J., Meier, W., \& Scambos, T. (2008). Arctic sea ice extent plummets in 2007. Eos (Washington, D. C.). 89(2), 1314. https://doi.org/10.1029/2008EO020001

Tanaka, M., Takahashi, Y., Yamaguchi, N., Kim, K., Zheng, G., \& Sakamitsu, M. (2013). The difference of diffusion coefficients in water for arsenic compounds at various $\mathrm{pH}$ and its dominant factors implied by molecular simulations. Geochimica et Cosmochimica Acta. 105, 360-371. https://doi.org/10.1016/j.gca.2012.12.004

Thanabalasingam, P., \& Pickering, W. (1986). Arsenic sorption by humic acids. Environmental Pollution. Series B. Chemical and Physical. 12(3), 233-246. https://doi.org/10.1016/0143$\underline{148 X(86) 90012-1}$

Thienpont, J. R., Korosi, J. B., Hargan, K. E., Eickmeyer, D. C., Kimpe, L. E., Palmer, M. J., Smol, J. P., Blais, J. M., Thienpont, R., David, D. C., Kimpe, L. E., Linda, J., Smol, P., Jules, M., \& Biais, B. M. (2016). Multi-trophic level response to extreme metal contamination from gold mining in a subarctic lake. Proceedings of the Royal Society. B, Biological Sciences, 283(1836), 20161125-. https://doi.org/10.1098/rspb.2016.1125

Toevs, G., Morra, M., Polizzotto, M., Strawn, D., Bostick, B., \& Fendorf, S. (2006). Metal(loid) diagenesis in mine-impacted sediments of lake coeur d'alene, idaho. Environmental Science \& Technology. 40(8), 2537-2543. https://doi.org/10.1021/es051781c

Tufano, K., Reyes, C., Saltikov, C., \& Fendorf, S. (2008). Reductive processes controlling arsenic retention: revealing the relative importance of iron and arsenic reduction. Environmental Science \& Technology. 42(22), 8283-8289. https://doi.org/10.1021/es801059s

Tyrrell, H. (1964). The origin and present status of Fick's diffusion law. Journal of Chemical Education. 41(7), 397-. https://doi.org/10.1021/ed041p397

Van Den Berghe, M. D., Jamieson, H. E., \& Palmer, M. J. (2018). Arsenic mobility and characterization in lakes impacted by gold ore roasting, Yellowknife, NWT, Canada. Environmental Pollution, 234, 630-641. https://doi.org/10.1016/j.envpol.2017.11.062

Veillette, J., Mueller, D.R., Antoniades, D., \& Vincent, W. F.. (2008). Arctic epishelf lakes as sentinel ecosystems: Past, present and future. Journal of Geophysical ResearchBiogeosciences. 113(G4), G04014-n/a. https://doi.org/10.1029/2008JG000730

Verburg, P., \& Hecky, R.E. (2009). The physics of the warming of Lake Tanganyika by climate change. Limnology and Oceanography. 54(6), 2418-2430.

https://doi.org/10.4319/1o.2009.54.6 part_2.2418

Vincent, W.F. (2009). Effects of climate change on lakes. in: likens, g.e., ed., encyclopedia of inland waters. Elsevier, Amsterdam, 55-60.

https://doi.org/10.1016/B978-012370626-3.00233-7 
Voegelin, A., Weber, F., \& Kretzschmar, R. (2007). Distribution and speciation of arsenic around roots in a contaminated riparian floodplain soil: Micro-XRF element mapping and EXAFS spectroscopy. Geochimica et Cosmochimica Acta. 71(23), 5804-5820.

https://doi.org/10.1016/j.gca.2007.05.030

Wagemann, R., Snow, N., Rosenberg, D., Lutz, A., \& Wagemann, R. (1978). Arsenic in sediments, water and aquatic biota from lakes in the vicinity of Yellowknife, Northwest Territories, Canada. Archives of Environmental Contamination and Toxicology. 7(2), 169-191. https://doi.org/10.1007/BF02332047

Wagner, C., \& Adrian, R. (2009). Cyanobacteria dominance: quantifying the effects of climate change. Limnology and Oceanography. 54(6), 2460-2468.

https://doi.org/10.4319/10.2009.54.6_part_2.2460

Walker, S., Jamieson, H., Lanzirotti, A., Andrade, C., \& Hall, G. (2005). The speciation of arsenic in iron oxides in mine wastes from the Giant gold mine, N.W.T.; application of synchrotron microXRD and micro-XANES at the grain scale. Canadian Mineralogist. 43(4), 1205-1224. https://doi.org/10.2113/gscanmin.43.4.1205

Walker, S., Jamieson, H., Lanzirotti, A., Hall, G., \& Peterson, R. (2015). The effect of ore roasting on arsenic oxidation state and solid phase speciation in gold mine tailings. Geochemistry: Exploration, Environment, Analysis. 15(4), 273-291. https://doi.org/10.1144/geochem2013-238.

Wang, S., \& Mulligan, C.N. (2006). Occurrence of arsenic contamination in Canada: Sources, behavior and distribution. Elsevier, Science of The Total Environment. 366(2-3), 701-721. https://doi.org/10.1016/i.scitotenv.2005.09.005

Wang, Y., Morin, G., Ona-Nguema, G., Menguy, N., Juillot, F., Aubry, E., Guyot, F., Calas, G., \& Brown, G. (2008). Arsenite sorption at the magnetite-water interface during aqueous precipitation of magnetite: EXAFS evidence for a new arsenite surface complex. Geochimica et Cosmochimica Acta. 72(11), 2573-2586. https://doi.org/10.1016/j.gca.2008.03.011

Weber, F. A., Hofacker, A. F., Voegelin, A., \& Kretzschmar, R. (2010). Temperature dependence and coupling of iron and arsenic reduction and release during flooding of a contaminated soil. Environmental Science and Technology. 44(1), 116-122.

https://doi.org/10.1021/es902100h

Western, S. A. (2021). Arsenic lost years: pollution control at giant mine from 1978 to 1999. Northern Review (Whitehorse). 51, 1-36. https://doi.org/10.22584/nr51.2021.004

WHO. (2017). Chapter 12. Chemical fact sheets, Arsenic. World Health Organization. Guidelines for drinking-water quality, 4th edition, incorporating the 1st addendum. 315-318. ISBN 978-92-4-154995-0.

WHO. (1993). Guidelines for drinking water quality, $2^{\text {nd }}$ ed. Recommendations. World Health Organization. 
Williamson, C.E., Saros, J.E., \& Schindler, D.W. (2009a). Sentinels of change. Science (American Association for the Advancement of Science). 323(5916), 887-888.

https://doi.org/10.1126/science.1169443

Williamson, C.E., Saros, J.E., Vincent, W.F., \& Smol, J.P. (2009b). Lakes and reservoirs as sentinels, integrators, and regulators of climate change. Limnol. Oceanogr. 54, 2273-2282. https://doi.org/10.4319/10.2009.54.6 part 2.2273.

Winder, M., Schindler, D.E., Essington, T.E., \& Litt, A.H. (2009). Disrupted seasonal clockwork in the population dynamics of a freshwater copepod by climate warming. Limnology and Oceanography. 54(6), 2493-2505. https://doi.org/10.4319/10.2009.54.6 part 2.2493

Wolfe, S., Stevens, C., Gaanderse, A., \& Oldenborger, G. (2014). Lithalsa distribution, morphology and landscape associations in the Great Slave Lowland, Northwest Territories, Canada. Geomorphology (Amsterdam, Netherlands). 204, 302-313.

https://doi.org/10.1016/j.geomorph.2013.08.014

Wolfe, S.A \& Morse, P.D. (2015). Holocene lake-level recession, permafrost aggradation and lithalsa formation in the Yellowknife area, Great Slave Lowland. In GEOQuébec2015: 68rd Canadian Geotechnical Conference \& $7^{\text {th }}$ Canadian Permafrost Conference. September 20-23, 2015, Québec City, Québec. Canadian Geotechnical Society: Richmond, B.C.

Wolthers, M., Charlet, L., van Der Weijden, C.H., Van Der Linde, P.R., \& Rickard, D. (2005). Arsenic mobility in the ambient sulfidic environment: Sorption of arsenic(V) and arsenic(III) onto disordered mackinawite. Geochimica et Cosmochimica Acta. 69(14), 3483-3492. https://doi.org/10.1016/j.gca.2005.03.003

Woodward, D., Farag, A., Bergman, H., DeLonay, A., Little, E., Smiths, C., \& Barrows, F. (1995). Metals-contaminated benthic invertebrates in the Clark Fork River Montana: effects on age-0 brown trout and rainbow trout. Canadian Journal of Fisheries and Aquatic Sciences. 52(9), 1994-2004. https://doi.org/10.1139/f95-791

Wrye, L.A. (2008). Distinguishing between natural and anthropogenic sources of arsenic in soils from the Giant Mine, Northwest Territoires and the North Brookfield Mine, Nova Scotia. MSc. Thesis. Queen's University, Kingston, Ontario, Canada. 241. ProQuest Dissertations Publishing.

$\mathrm{Xu}, \mathrm{H} .$, Allard, B., \& Grimvall, a. (1988). Influence of $\mathrm{pH}$ and organic substance on the adsorption of As(V) on geologic materials. Water, Air, and Soil Pollution. 40(3-4), 293-305.

Xu, H., Allard, B., \& Grimvall, A. (1991). Effects of acidification and natural organic materials on the mobility of arsenic in the environment. Water, Air and Soil Pollution. 57-58(1), 269-278. https://doi.org/10.1007/BF00282890

Zobrist, J., Dowdle, P., Davis, J., \& Oremland, R. (2000). Mobilization of arsenite by dissimilatory reduction of adsorbed arsenate. Environmental Science \& Technology. 34(22), 4747-4753. https://doi.org/10.1021/es001068h 


\section{APPENDICES}

\section{A. Surface Water, Porewater and Sediment Characteristics}

Table 6.1: Surface water sampled at the beginning and end of the experiment was analyzed for a suite of 25 elements by ICP-MS for background water chemistry at Taiga Environmental Laboratory in Yellowknife. Values shaded red were below the method detection limit (MDL).

\begin{tabular}{|c|c|c|c|c|c|c|c|c|}
\hline Elements & $\begin{array}{l}\text { C2.1 } \\
\text { D0 } \\
(u g / L)\end{array}$ & $\begin{array}{l}\text { C2.1 } \\
\text { D36 } \\
(u g / L)\end{array}$ & $\begin{array}{l}\text { C2.2 } \\
\text { D0 } \\
(\mathrm{ug} / \mathrm{L})\end{array}$ & $\begin{array}{l}\text { C2.2 } \\
\text { D36 } \\
(u g / L)\end{array}$ & $\begin{array}{l}\text { C2.3 } \\
\text { D0 } \\
(u g / L)\end{array}$ & $\begin{array}{l}\text { C2.3 } \\
\text { D36 } \\
(u g / L)\end{array}$ & $\begin{array}{l}\text { C2.4 } \\
\text { D0 } \\
(u g / L)\end{array}$ & $\begin{array}{l}\text { C2.4 } \\
\text { D36 } \\
(\mathrm{ug} / \mathrm{L})\end{array}$ \\
\hline Aluminum & 21.6 & 12.2 & 16.9 & 8.9 & 58 & 4 & 4.9 & 3.9 \\
\hline Antimony & 4.7 & 4.1 & 2.1 & 2.1 & 56.1 & 179 & 46.6 & 144 \\
\hline Arsenic & 58 & 112 & 34.2 & 58.5 & 23.5 & 88.2 & 22.6 & 72.8 \\
\hline Barium & 17.3 & 27.9 & 16.3 & 15.6 & 20.2 & 84.9 & 20.3 & 105 \\
\hline Beryllium & 0.1 & 0.1 & 0.1 & 0.1 & 0.1 & 0.1 & 0.1 & 0.1 \\
\hline Cadmium & 0.04 & 0.04 & 0.04 & 0.04 & 0.04 & 0.09 & 0.04 & 0.14 \\
\hline Cesium & 0.1 & 0.2 & 0.1 & 0.2 & 0.1 & 0.1 & 0.1 & 0.2 \\
\hline Chromium & 0.1 & 0.1 & 0.1 & 0.1 & 0.2 & 0.1 & 0.1 & 0.1 \\
\hline Cobalt & 0.1 & 0.3 & 0.1 & 0.1 & 0.4 & 0.5 & 0.2 & 0.5 \\
\hline Copper & 0.5 & 0.9 & 0.5 & 0.5 & 2.5 & 7.5 & 2.6 & 7.3 \\
\hline Iron & 33 & 41 & 36 & 8 & 5 & 5 & 5 & 5 \\
\hline Lead & 0.1 & 0.1 & 0.1 & 0.1 & 0.1 & 0.1 & 0.1 & 0.1 \\
\hline Lithium & 2.3 & 3.1 & 2.4 & 3 & 2.5 & 6.9 & 2.5 & 6.6 \\
\hline Manganese & 3.2 & 4.7 & 4.1 & 0.5 & 168 & 41.8 & 48.6 & 47.6 \\
\hline Molybdenum & 0.9 & 1 & 0.4 & 0.4 & 0.3 & 1.5 & 0.2 & 1.4 \\
\hline Nickel & 0.3 & 0.5 & 0.2 & 0.7 & 4.5 & 9.3 & 4.3 & 7.4 \\
\hline Rubidium & 2.7 & 4.8 & 2.7 & 4.9 & 1.8 & 7.4 & 2 & 7.9 \\
\hline Selenium & 0.3 & 0.3 & 0.3 & 0.3 & 0.3 & 0.5 & 0.3 & 0.5 \\
\hline Silver & 0.6 & 0.6 & 1.2 & 0.5 & 0.6 & 2.8 & 1.4 & 4.1 \\
\hline Strontium & 47.6 & 61.7 & 48.1 & 56.9 & 49.5 & 173 & 49.5 & 173 \\
\hline Thallium & 0.1 & 0.1 & 0.1 & 0.1 & 0.1 & 0.1 & 0.1 & 0.1 \\
\hline Titanium & 0.3 & 0.3 & 0.2 & 0.2 & 0.2 & 0.2 & 0.2 & 0.2 \\
\hline Uranium & 0.3 & 0.1 & 0.2 & 0.1 & 0.1 & 0.1 & 0.1 & 0.1 \\
\hline Vanadium & 1.3 & 0.5 & 0.5 & 0.2 & 0.1 & 0.3 & 0.1 & 0.3 \\
\hline Zinc & 1.9 & 1.4 & 1.2 & 1.4 & 20.9 & 36.4 & 27.9 & 34 \\
\hline
\end{tabular}


Table 6.2: General water quality measured in the stock surface water added to the cores and the surface waters at the end of the experiment. The chemical analyses were performed at Caduceon Environmental Laboratory in Ottawa.

\begin{tabular}{|c|c|c|c|c|c|c|c|c|}
\hline Parameter & Units & MDL & C2.1 & $\mathrm{C} 2.2$ & $\mathrm{C} 2.3$ & $\mathrm{C} 2.4$ & $\begin{array}{c}\text { Lower } \\
\text { Martin Lake } \\
\text { Stock }\end{array}$ & $\begin{array}{c}\text { Yellowknife } \\
\text { Bay } \\
\text { Stock }\end{array}$ \\
\hline Hardness (as CaCO3) & $\mathrm{mg} / \mathrm{L}$ & 1 & 55 & 52 & 143 & 120 & 65 & 24 \\
\hline $\begin{array}{l}\text { Alkalinity }(\mathrm{CaCO} 3) \text { to } \\
\text { pH4.5 }\end{array}$ & $\mathrm{mg} / \mathrm{L}$ & 5 & 59 & 52 & 39 & 33 & 96 & 18 \\
\hline Fluoride & $\mathrm{mg} / \mathrm{L}$ & 0.1 & $<0.1$ & $<0.1$ & $<0.1$ & $<0.1$ & $<0.1$ & $<0.1$ \\
\hline Chloride & $\mathrm{mg} / \mathrm{L}$ & 0.5 & 20.8 & 30.7 & 19.8 & 28.6 & 5.1 & 2.7 \\
\hline Calcium & $\mathrm{mg} / \mathrm{L}$ & 0.02 & 15.1 & 14.1 & 37.5 & 31.8 & 17.2 & 5.68 \\
\hline Magnesium & $\mathrm{mg} / \mathrm{L}$ & 0.02 & 4.11 & 3.96 & 12.1 & 9.81 & 5.27 & 2.34 \\
\hline Sodium & $\mathrm{mg} / \mathrm{L}$ & 0.2 & 3.9 & 4.1 & 5.2 & 4.9 & 4.3 & 2.5 \\
\hline Potassium & $\mathrm{mg} / \mathrm{L}$ & 0.1 & 21.7 & 34.7 & 21.3 & 27.5 & 1 & 1.1 \\
\hline
\end{tabular}

Table 6.3: Surface water of the four sediment cores in the experiment were analyzed by ICP-MS for water chemistry at Taiga Environmental Laboratory in Yellowknife. Values shaded red were below the MDL.

\begin{tabular}{|c|c|c|c|c|c|c|c|c|c|c|}
\hline Core & Date & Sample ID & $\begin{array}{l}\text { Sample } \\
\text { Day }\end{array}$ & $\begin{array}{l}\text { Water } \\
\text { Vol. } \\
\text { (L) }\end{array}$ & $\begin{array}{l}{[\mathbf{A s}]} \\
\mathbf{u g} / \mathbf{L}\end{array}$ & $\begin{array}{l}\text { Mass } \\
\text { As } \\
\text { (ug) } \\
\end{array}$ & $\begin{array}{l}{[\mathrm{Fe}]} \\
\mathrm{ug} / \mathrm{L}\end{array}$ & $\begin{array}{l}\text { Mass } \\
\text { Fe } \\
\text { (ug) } \\
\end{array}$ & $\begin{array}{l}{[\mathrm{Mn}]} \\
\mathrm{ug} / \mathrm{L}\end{array}$ & $\begin{array}{l}\text { Mass } \\
\text { Mn } \\
\text { (ug) } \\
\end{array}$ \\
\hline 2.1 & 17-Jun-19 & $\mathrm{C} 2.1 \mathrm{D}=0$ & 0 & 1.423 & 58.0 & 82.5 & 33.0 & 47.0 & 3.2 & 4.6 \\
\hline 2.1 & 18-Jun-19 & $\mathrm{C} 2.1 \mathrm{D}=1$ & 1 & 1.386 & 56.4 & 78.2 & 31.0 & 43.0 & 2.4 & 3.3 \\
\hline 2.1 & 19-Jun-19 & $\mathrm{C} 2.1 \mathrm{D}=2$ & 2 & 1.381 & 62.5 & 86.3 & 31.0 & 42.8 & 2.4 & 3.3 \\
\hline 2.1 & 21-Jun-19 & $\mathrm{C} 2.1 \mathrm{D}=4$ & 4 & 1.376 & 65.7 & 90.4 & 36.0 & 49.5 & 1.7 & 2.3 \\
\hline 2.1 & 24-Jun-19 & $\mathrm{C} 2.1 \mathrm{D}=7$ & 7 & 1.371 & 66.7 & 91.5 & 26.0 & 35.7 & 1.1 & 1.5 \\
\hline 2.1 & 25-Jun-19 & $\mathrm{C} 2.1 \mathrm{D}=8$ & 8 & 1.351 & 72.4 & 97.8 & 31.0 & 41.9 & 2.0 & 2.7 \\
\hline 2.1 & 26-Jun-19 & $\mathrm{C} 2.1 \mathrm{D}=9$ & 9 & 1.346 & 74.4 & 100.2 & 29.0 & 39.0 & 1.4 & 1.9 \\
\hline 2.1 & 28-Jun-19 & $\mathrm{C} 2.1 \mathrm{D}=11$ & 11 & 1.341 & 77.9 & 104.5 & 27.0 & 36.2 & 0.9 & 1.2 \\
\hline 2.1 & 02-Jul-19 & $\mathrm{C} 2.1 \mathrm{D}=15$ & 15 & 1.336 & 85.0 & 113.6 & 22.0 & 29.4 & 0.8 & 1.1 \\
\hline 2.1 & 03-Jul-19 & $\mathrm{C} 2.1 \mathrm{D}=16$ & 16 & 1.316 & 84.3 & 111.0 & 25.0 & 32.9 & 2.3 & 3.0 \\
\hline 2.1 & 04-Jul-19 & $\mathrm{C} 2.1 \mathrm{D}=17$ & 17 & 1.311 & 84.8 & 111.2 & 26.0 & 34.1 & 2.0 & 2.6 \\
\hline 2.1 & 08-Jul-19 & $\mathrm{C} 2.1 \mathrm{D}=21$ & 21 & 1.306 & 86.3 & 112.7 & 31.0 & 40.5 & 1.8 & 2.4 \\
\hline
\end{tabular}




\begin{tabular}{|c|c|c|c|c|c|c|c|c|c|c|}
\hline 2.1 & 09-Jul-19 & $\mathrm{C} 2.1 \mathrm{D}=22$ & 22 & 1.301 & 101.0 & 131.4 & 35.0 & 45.5 & 1.6 & 2.1 \\
\hline 2.1 & 10-Jul-19 & $\mathrm{C} 2.1 \mathrm{D}=23$ & 23 & 1.281 & 101.0 & 129.4 & 43.0 & 55.1 & 1.8 & 2.3 \\
\hline 2.1 & 11-Jul-19 & $\mathrm{C} 2.1 \mathrm{D}=24$ & 24 & 1.276 & 109.0 & 139.1 & 37.0 & 47.2 & 2.1 & 2.7 \\
\hline 2.1 & 15-Jul-19 & $\mathrm{C} 2.1 \mathrm{D}=28$ & 28 & 1.271 & 110.0 & 139.8 & 41.0 & 52.1 & 1.4 & 1.8 \\
\hline 2.1 & 16-Jul-19 & $\mathrm{C} 2.1 \mathrm{D}=29$ & 29 & 1.266 & 112.0 & 141.8 & 38.0 & 48.1 & 1.1 & 1.4 \\
\hline 2.1 & 17-Jul-19 & $\mathrm{C} 2.1 \mathrm{D}=30$ & 30 & 1.246 & 111.0 & 138.3 & 37.0 & 46.1 & 1.9 & 2.4 \\
\hline 2.1 & 18-Jul-19 & $\mathrm{C} 2.1 \mathrm{D}=31$ & 31 & 1.241 & 116.0 & 144.0 & 39.0 & 48.4 & 6.7 & 8.3 \\
\hline 2.1 & 22-Jul-19 & $\mathrm{C} 2.1 \mathrm{D}=35$ & 35 & 1.236 & 107.0 & 132.3 & 42.0 & 51.9 & 5.4 & 6.7 \\
\hline 2.1 & 23-Jul-19 & $\mathrm{C} 2.1 \mathrm{D}=36$ & 36 & 1.231 & 112.0 & 137.9 & 41.0 & 50.5 & 4.7 & 5.8 \\
\hline 2.2 & 17-Jun-19 & $\mathrm{C} 2.2 \mathrm{D}=0$ & 0 & 1.445 & 34.2 & 49.4 & 36.0 & 52.0 & 4.1 & 5.9 \\
\hline 2.2 & 18-Jun-19 & $\mathrm{C} 2.2 \mathrm{D}=1$ & 1 & 1.425 & 33.9 & 48.3 & 36.0 & 51.3 & 3.2 & 4.6 \\
\hline 2.2 & 19-Jun-19 & $\mathrm{C} 2.2 \mathrm{D}=2$ & 2 & 1.420 & 34.8 & 49.4 & 32.0 & 45.4 & 3.3 & 4.7 \\
\hline 2.2 & 21-Jun-19 & $\mathrm{C} 2.2 \mathrm{D}=4$ & 4 & 1.415 & 35.2 & 49.8 & 28.0 & 39.6 & 3.5 & 5.0 \\
\hline 2.2 & 24-Jun-19 & $\mathrm{C} 2.2 \mathrm{D}=7$ & 7 & 1.405 & 36.7 & 51.6 & 18.0 & 25.3 & 0.2 & 0.3 \\
\hline 2.2 & 25-Jun-19 & $\mathrm{C} 2.2 \mathrm{D}=8$ & 8 & 1.385 & 36.4 & 50.4 & 17.0 & 23.5 & 0.8 & 1.1 \\
\hline 2.2 & 26-Jun-19 & $\mathrm{C} 2.2 \mathrm{D}=9$ & 9 & 1.380 & 37.5 & 51.7 & 16.0 & 22.1 & 0.5 & 0.7 \\
\hline 2.2 & 28-Jun-19 & $\mathrm{C} 2.2 \mathrm{D}=11$ & 11 & 1.375 & 38.0 & 52.2 & 15.0 & 20.6 & 0.5 & 0.7 \\
\hline 2.2 & 02-Jul-19 & $\mathrm{C} 2.2 \mathrm{D}=15$ & 15 & 1.370 & 41.8 & 57.3 & 13.0 & 17.8 & 0.5 & 0.7 \\
\hline 2.2 & 03-Jul-19 & $\mathrm{C} 2.2 \mathrm{D}=16$ & 16 & 1.350 & 41.1 & 55.5 & 19.0 & 25.6 & 1.7 & 2.3 \\
\hline 2.2 & 04-Jul-19 & $\mathrm{C} 2.2 \mathrm{D}=17$ & 17 & 1.345 & 42.8 & 57.6 & 17.0 & 22.9 & 0.9 & 1.2 \\
\hline 2.2 & 08-Jul-19 & $\mathrm{C} 2.2 \mathrm{D}=21$ & 21 & 1.340 & 43.1 & 57.8 & 15.0 & 20.1 & 0.6 & 0.8 \\
\hline 2.2 & 09-Jul-19 & $\mathrm{C} 2.2 \mathrm{D}=22$ & 22 & 1.335 & 46.2 & 61.7 & 15.0 & 20.0 & 0.6 & 0.8 \\
\hline 2.2 & 10-Jul-19 & $\mathrm{C} 2.2 \mathrm{D}=23$ & 23 & 1.298 & 44.5 & 57.8 & 15.0 & 19.5 & 0.8 & 1.0 \\
\hline 2.2 & 11-Jul-19 & $\mathrm{C} 2.2 \mathrm{D}=24$ & 24 & 1.293 & 45.5 & 58.8 & 15.0 & 19.4 & 0.5 & 0.6 \\
\hline 2.2 & 15-Jul-19 & $\mathrm{C} 2.2 \mathrm{D}=28$ & 28 & 1.288 & 47.1 & 60.7 & 13.0 & 16.7 & 0.4 & 0.5 \\
\hline 2.2 & 16-Jul-19 & $\mathrm{C} 2.2 \mathrm{D}=29$ & 29 & 1.278 & 49.8 & 63.6 & 10.0 & 12.8 & 0.2 & 0.3 \\
\hline 2.2 & 17-Jul-19 & $\mathrm{C} 2.2 \mathrm{D}=30$ & 30 & 1.258 & 49.7 & 62.5 & 11.0 & 13.8 & 0.8 & 1.0 \\
\hline 2.2 & 18-Jul-19 & $\mathrm{C} 2.2 \mathrm{D}=31$ & 31 & 1.253 & 51.6 & 64.7 & 10.0 & 12.5 & 0.8 & 1.0 \\
\hline 2.2 & 22-Jul-19 & $\mathrm{C} 2.2 \mathrm{D}=35$ & 35 & 1.248 & 55.5 & 69.3 & 10.0 & 12.5 & 1.2 & 1.5 \\
\hline 2.2 & 23-Jul-19 & $\mathrm{C} 2.2 \mathrm{D}=36$ & 36 & 1.226 & 58.5 & 71.7 & 8.0 & 9.8 & 0.5 & 0.6 \\
\hline 2.3 & 17-Jun-19 & $\mathrm{C} 2.3 \mathrm{D}=0$ & 0 & 1.307 & 23.5 & 30.7 & 5.0 & 6.5 & 168.0 & 219.6 \\
\hline 2.3 & 18-Jun-19 & $\mathrm{C} 2.3 \mathrm{D}=1$ & 1 & 1.290 & 25.9 & 33.4 & 5.0 & 6.4 & 186.0 & 239.9 \\
\hline 2.3 & 19-Jun-19 & $\mathrm{C} 2.3 \mathrm{D}=2$ & 2 & 1.285 & 33.2 & 42.7 & 5.0 & 6.4 & 196.0 & 251.9 \\
\hline 2.3 & 21-Jun-19 & $\mathrm{C} 2.3 \mathrm{D}=4$ & 4 & 1.280 & 44.2 & 56.6 & 5.0 & 6.4 & 204.0 & 261.1 \\
\hline 2.3 & 24-Jun-19 & $\mathrm{C} 2.3 \mathrm{D}=7$ & 7 & 1.275 & 54.6 & 69.6 & 5.0 & 6.4 & 212.0 & 270.3 \\
\hline 2.3 & 25-Jun-19 & $\mathrm{C} 2.3 \mathrm{D}=8$ & 8 & 1.258 & 55.8 & 70.2 & 5.0 & 6.3 & 199.0 & 250.3 \\
\hline 2.3 & 26-Jun-19 & $\mathrm{C} 2.3 \mathrm{D}=9$ & 9 & 1.253 & 58.3 & 73.0 & 7.0 & 8.8 & 195.0 & 244.3 \\
\hline 2.3 & 28-Jun-19 & $\mathrm{C} 2.3 \mathrm{D}=11$ & 11 & 1.243 & 61.5 & 76.4 & 5.0 & 6.2 & 175.0 & 217.5 \\
\hline 2.3 & 02-Jul-19 & $\mathrm{C} 2.3 \mathrm{D}=15$ & 15 & 1.238 & 68.7 & 85.0 & 5.0 & 6.2 & 139.0 & 172.1 \\
\hline 2.3 & 03-Jul-19 & $\mathrm{C} 2.3 \mathrm{D}=16$ & 16 & 1.221 & 67.1 & 81.9 & 5.0 & 6.1 & 120.0 & 146.5 \\
\hline 2.3 & 04-Jul-19 & $\mathrm{C} 2.3 \mathrm{D}=17$ & 17 & 1.216 & 68.5 & 83.3 & 5.0 & 6.1 & 108.0 & 131.3 \\
\hline 2.3 & 08-Jul-19 & $\mathrm{C} 2.3 \mathrm{D}=21$ & 21 & 1.211 & 73.2 & 88.6 & 5.0 & 6.1 & 64.4 & 78.0 \\
\hline
\end{tabular}




\begin{tabular}{|c|c|c|c|c|c|c|c|c|c|c|}
\hline 2.3 & 09-Jul-19 & $\mathrm{C} 2.3 \mathrm{D}=22$ & 22 & 1.206 & 78.9 & 95.2 & 5.0 & 6.0 & 56.0 & 67.5 \\
\hline 2.3 & 10-Jul-19 & $\mathrm{C} 2.3 \mathrm{D}=23$ & 23 & 1.189 & 77.3 & 91.9 & 5.0 & 5.9 & 44.8 & 53.3 \\
\hline 2.3 & 11-Jul-19 & $\mathrm{C} 2.3 \mathrm{D}=24$ & 24 & 1.184 & 79.3 & 93.9 & 35.0 & 41.4 & 37.1 & 43.9 \\
\hline 2.3 & 15-Jul-19 & $\mathrm{C} 2.3 \mathrm{D}=28$ & 28 & 1.179 & 85.6 & 100.9 & 5.0 & 5.9 & 13.6 & 16.0 \\
\hline 2.3 & 16-Jul-19 & $\mathrm{C} 2.3 \mathrm{D}=29$ & 29 & 1.174 & 89.0 & 104.5 & 5.0 & 5.9 & 10.0 & 11.7 \\
\hline 2.3 & 17-Jul-19 & $\mathrm{C} 2.3 \mathrm{D}=30$ & 30 & 1.157 & 87.7 & 101.5 & 5.0 & 5.8 & 8.0 & 9.3 \\
\hline 2.3 & 18-Jul-19 & $\mathrm{C} 2.3 \mathrm{D}=31$ & 31 & 1.152 & 86.8 & 100.0 & 5.0 & 5.8 & 6.3 & 7.3 \\
\hline 2.3 & 22-Jul-19 & $\mathrm{C} 2.3 \mathrm{D}=35$ & 35 & 1.142 & 85.7 & 97.9 & 5.0 & 5.7 & 22.7 & 25.9 \\
\hline 2.3 & 23-Jul-19 & $\mathrm{C} 2.3 \mathrm{D}=36$ & 36 & 1.137 & 88.2 & 100.3 & 5.0 & 5.7 & 41.8 & 47.5 \\
\hline 2.4 & 17-Jun-19 & $\mathrm{C} 2.4 \mathrm{D}=0$ & 0 & 1.307 & 22.6 & 29.5 & 5.0 & 6.5 & 48.6 & 63.5 \\
\hline 2.4 & 18-Jun-19 & $\mathrm{C} 2.4 \mathrm{D}=1$ & 1 & 1.290 & 23.1 & 29.8 & 5.0 & 6.4 & 46.3 & 59.7 \\
\hline 2.4 & 19-Jun-19 & $\mathrm{C} 2.4 \mathrm{D}=2$ & 2 & 1.285 & 28.7 & 36.9 & 5.0 & 6.4 & 46.5 & 59.8 \\
\hline 2.4 & 21-Jun-19 & $\mathrm{C} 2.4 \mathrm{D}=4$ & 4 & 1.280 & 37.1 & 47.5 & 5.0 & 6.4 & 42.9 & 54.9 \\
\hline 2.4 & 24-Jun-19 & $\mathrm{C} 2.4 \mathrm{D}=7$ & 7 & 1.275 & 45.4 & 57.9 & 5.0 & 6.4 & 35.9 & 45.8 \\
\hline 2.4 & 25-Jun-19 & $\mathrm{C} 2.4 \mathrm{D}=8$ & 8 & 1.258 & 46.9 & 59.0 & 5.0 & 6.3 & 31.5 & 39.6 \\
\hline 2.4 & 26-Jun-19 & $\mathrm{C} 2.4 \mathrm{D}=9$ & 9 & 1.253 & 48.6 & 60.9 & 5.0 & 6.3 & 28.8 & 36.1 \\
\hline 2.4 & 28-Jun-19 & $\mathrm{C} 2.4 \mathrm{D}=11$ & 11 & 1.243 & 51.1 & 63.5 & 5.0 & 6.2 & 23.1 & 28.7 \\
\hline 2.4 & 02-Jul-19 & $\mathrm{C} 2.4 \mathrm{D}=15$ & 15 & 1.238 & 57.2 & 70.8 & 5.0 & 6.2 & 14.8 & 18.3 \\
\hline 2.4 & 03-Jul-19 & $\mathrm{C} 2.4 \mathrm{D}=16$ & 16 & 1.221 & 56.8 & 69.4 & 5.0 & 6.1 & 12.3 & 15.0 \\
\hline 2.4 & 04-Jul-19 & $\mathrm{C} 2.4 \mathrm{D}=17$ & 17 & 1.216 & 57.7 & 70.2 & 5.0 & 6.1 & 10.8 & 13.1 \\
\hline 2.4 & 08-Jul-19 & $\mathrm{C} 2.4 \mathrm{D}=21$ & 21 & 1.211 & 61.2 & 74.1 & 5.0 & 6.1 & 5.9 & 7.1 \\
\hline 2.4 & 09-Jul-19 & $\mathrm{C} 2.4 \mathrm{D}=22$ & 22 & 1.206 & 66.4 & 80.1 & 5.0 & 6.0 & 5.3 & 6.4 \\
\hline 2.4 & 10-Jul-19 & $\mathrm{C} 2.4 \mathrm{D}=23$ & 23 & 1.189 & 64.6 & 76.8 & 8.0 & 9.5 & 5.1 & 6.1 \\
\hline 2.4 & 11-Jul-19 & $\mathrm{C} 2.4 \mathrm{D}=24$ & 24 & 1.184 & 66.7 & 79.0 & 5.0 & 5.9 & 4.3 & 5.1 \\
\hline 2.4 & 15-Jul-19 & $\mathrm{C} 2.4 \mathrm{D}=28$ & 28 & 1.179 & 70.9 & 83.6 & 5.0 & 5.9 & 2.9 & 3.4 \\
\hline 2.4 & 16-Jul-19 & $\mathrm{C} 2.4 \mathrm{D}=29$ & 29 & 1.174 & 75.2 & 88.3 & 5.0 & 5.9 & 2.2 & 2.6 \\
\hline 2.4 & 17-Jul-19 & $\mathrm{C} 2.4 \mathrm{D}=30$ & 30 & 1.157 & 73.0 & 84.5 & 5.0 & 5.8 & 1.9 & 2.2 \\
\hline 2.4 & 18-Jul-19 & $\mathrm{C} 2.4 \mathrm{D}=31$ & 31 & 1.152 & 74.5 & 85.8 & 5.0 & 5.8 & 2.2 & 2.5 \\
\hline 2.4 & 22-Jul-19 & $\mathrm{C} 2.4 \mathrm{D}=35$ & 35 & 1.147 & 69.1 & 79.3 & 6.0 & 6.9 & 28.0 & 32.1 \\
\hline 2.4 & 23-Jul-19 & $\mathrm{C} 2.4 \mathrm{D}=36$ & 36 & 1.142 & 72.8 & 83.1 & 5.0 & 5.7 & 47.6 & 54.4 \\
\hline
\end{tabular}


Table 6.4: Porewater concentrations of Lower Martin Lake sediment measured weekly during the incubation experiment. Element concentrations were measured by ICP-MS at Taiga Environmental Laboratory in Yellowknife.

\begin{tabular}{|r|r|r|l|l|r|r|r|r|r|}
\hline Core & Points & \multicolumn{1}{|l|}{ Date } & Sample ID & \multicolumn{1}{l|}{ Core } & $\begin{array}{l}\text { Sample } \\
\text { Day }\end{array}$ & $\begin{array}{l}\text { Temp. } \\
\left({ }^{\circ} \mathrm{C}\right)\end{array}$ & $\begin{array}{l}\text { As.Conc } \\
(\mu \mathrm{g} / \mathrm{L})\end{array}$ & $\begin{array}{l}\text { Fe.Conc } \\
(\mu \mathrm{g} / \mathrm{L})\end{array}$ & $\begin{array}{l}\text { Mn.Conc } \\
(\mu \mathrm{g} / \mathrm{L})\end{array}$ \\
\hline 2.1 & 1 & 17-Jun-19 & $\mathrm{C} 2.1 \mathrm{D}=0$ & 2.1 & 0 & 7.5 & 124 & 78 & 45.4 \\
\hline 2.1 & 2 & 24-Jun-19 & $\mathrm{C} 2.1 \mathrm{D}=7$ & 2.1 & 7 & 7.5 & 101 & 23 & 4 \\
\hline 2.1 & 3 & 02-Jul-19 & $\mathrm{C} 2.1 \mathrm{D}=15$ & 2.1 & 15 & 12.2 & 86 & 24 & 1.1 \\
\hline 2.1 & 4 & 08-Jul-19 & $\mathrm{C} 2.1 \mathrm{D}=22$ & 2.1 & 22 & 18.3 & 102 & 38 & 2.2 \\
\hline 2.1 & 5 & 16-Jul-19 & $\mathrm{C} 2.1 \mathrm{D}=29$ & 2.1 & 29 & 21.5 & 110 & 65 & 23.3 \\
\hline 2.2 & 6 & 17-Jun-19 & $\mathrm{C} 2.2 \mathrm{D}=0$ & 2.2 & 0 & 7.5 & 42.5 & 463 & 231 \\
\hline 2.2 & 7 & 24-Jun-19 & $\mathrm{C} 2.2 \mathrm{D}=7$ & 2.2 & 7 & 7.5 & 32.3 & 396 & 177 \\
\hline 2.2 & 8 & 02-Jul-19 & $\mathrm{C} 2.2 \mathrm{D}=15$ & 2.2 & 15 & 12.2 & 40.6 & 343 & 165 \\
\hline 2.2 & 9 & 08-Jul-19 & $\mathrm{C} 2.2 \mathrm{D}=22$ & 2.2 & 22 & 18.3 & 58 & 419 & 193 \\
\hline 2.2 & 10 & 16-Jul-19 & $\mathrm{C} 2.2 \mathrm{D}=29$ & 2.2 & 29 & 21.5 & 48.5 & 944 & 364 \\
\hline
\end{tabular}


Table 6.5: Chemical analysis for Yellowknife Bay and Lower Martin Lake sediment used in the incubation experiment. Element concentrations were measured by ICP-MS at Bureau Veritas in Vancouver, BC.

\begin{tabular}{|c|c|c|c|c|c|}
\hline & Method & AQ250 & AQ250 & AQ250 & AQ250 \\
\hline & Analyte & Mn & $\mathrm{Fe}$ & As & $\mathbf{S}$ \\
\hline & Unit & PPM & $\%$ & PPM & $\%$ \\
\hline & MDL & 1 & 0.01 & 0.1 & 0.02 \\
\hline Sample & Type & & & & \\
\hline $\mathrm{C} 2.30-1 \mathrm{~cm}$ & Lake Sediment & 1300 & 4.24 & 2009.3 & 0.11 \\
\hline $\mathrm{C} 2.31-1.5 \mathrm{~cm}$ & Lake Sediment & 678 & 3.99 & 1961.5 & 0.15 \\
\hline $\mathrm{C} 2.31 .5-2 \mathrm{~cm}$ & Lake Sediment & 636 & 3.83 & 1334.4 & 0.17 \\
\hline $\mathrm{C} 2.32-2.5 \mathrm{~cm}$ & Lake Sediment & 674 & 3.8 & 1496.8 & 0.17 \\
\hline $\mathrm{C} 2.32 .5-3 \mathrm{~cm}$ & Lake Sediment & 693 & 3.88 & 1852.7 & 0.15 \\
\hline $\mathrm{C} 2.33-3.5 \mathrm{~cm}$ & Lake Sediment & 698 & 3.9 & 1536.9 & 0.17 \\
\hline $\mathrm{C} 2.33 .5-4 \mathrm{~cm}$ & Lake Sediment & 697 & 3.96 & 1573 & 0.2 \\
\hline $\mathrm{C} 2.34-4.5 \mathrm{~cm}$ & Lake Sediment & 692 & 4.05 & 1657.5 & 0.2 \\
\hline $\mathrm{C} 2.34 .5-5 \mathrm{~cm}$ & Lake Sediment & 677 & 4.17 & 1753.8 & 0.21 \\
\hline $\mathrm{C} 2.40-1 \mathrm{~cm}$ & Lake Sediment & 845 & 4.06 & 1646.1 & 0.14 \\
\hline $\mathrm{C} 2.41-1.5 \mathrm{~cm}$ & Lake Sediment & 645 & 4.08 & 1802.8 & 0.18 \\
\hline $\mathrm{C} 2.41 .5-2 \mathrm{~cm}$ & Lake Sediment & 645 & 4.05 & 1888 & 0.18 \\
\hline $\mathrm{C} 2.42-2.5 \mathrm{~cm}$ & Lake Sediment & 672 & 3.96 & 1538.9 & 0.18 \\
\hline $\mathrm{C} 2.42 .5-3 \mathrm{~cm}$ & Lake Sediment & 660 & 3.94 & 1475.3 & 0.19 \\
\hline $\mathrm{C} 2.43-3.5 \mathrm{~cm}$ & Lake Sediment & 696 & 4.05 & 1564.6 & 0.18 \\
\hline $\mathrm{C} 2.43 .5-4 \mathrm{~cm}$ & Lake Sediment & 715 & 4.12 & 1706.2 & 0.19 \\
\hline $\mathrm{C} 2.44-4.5 \mathrm{~cm}$ & Lake Sediment & 684 & 4.03 & 1604.3 & 0.19 \\
\hline $\mathrm{C} 2.44 .5-5 \mathrm{~cm}$ & Lake Sediment & 705 & 4.17 & 1748.3 & 0.19 \\
\hline $\mathrm{C} 2.10-3 \mathrm{~cm}$ & Lake Sediment & 203 & 0.94 & 805.5 & 1.36 \\
\hline $\mathrm{C} 2.20-3 \mathrm{~cm}$ & Lake Sediment & 151 & 1 & 838.1 & 1.42 \\
\hline PACS-2A & Lake Sediment & 247 & 3.07 & 23.9 & 1.25 \\
\hline PACS-2B & Lake Sediment & 240 & 2.99 & 23.5 & 1.21 \\
\hline \multicolumn{6}{|l|}{ Pulp Duplicates } \\
\hline $\mathrm{C} 2.31-1.5 \mathrm{~cm}$ & Lake Sediment & 678 & 3.99 & 1961.5 & 0.15 \\
\hline $\mathrm{C} 2.31-1.5 \mathrm{~cm}$ & REP & 662 & 3.94 & 1934.1 & 0.15 \\
\hline
\end{tabular}




\begin{tabular}{|c|c|c|c|c|c|}
\hline $\begin{array}{l}\text { Reference } \\
\text { Materials }\end{array}$ & & & & & \\
\hline STD DS11 & STD & 1034 & 3.1 & 43.2 & 0.27 \\
\hline STD OREAS262 & STD & 537 & 3.23 & 35.4 & 0.26 \\
\hline STD DS11 & STD & 988 & 3.07 & 42.6 & 0.26 \\
\hline STD OREAS262 & STD & 529 & 3.22 & 35.8 & 0.25 \\
\hline STD BVGEO01 & STD & 724 & 3.68 & 118.4 & 0.64 \\
\hline STD OREAS262 & STD & 517 & 3.16 & 35.8 & 0.24 \\
\hline BLK & BLK & $<1$ & $<0.01$ & $<0.1$ & $<0.02$ \\
\hline BLK & BLK & $<1$ & $<0.01$ & $<0.1$ & $<0.02$ \\
\hline BLK & BLK & $<1$ & $<0.01$ & 0.2 & $<0.02$ \\
\hline
\end{tabular}

\section{B. Fick's First Law Data}

Table 6.6: Calculated Viscosity Coefficient and Diffusion coefficient at given Ambient Temperatures.

\begin{tabular}{|c|c|c|}
\hline Ambient Temperatures $\left({ }^{\circ} \mathrm{C}\right)$ & Viscosity (mPa/s) & Diffusion $\left(\mathbf{c m}^{2} / \mathbf{s}\right)$ \\
\hline 7 & 1.415 & $5.17 \times 10^{-6}$ \\
\hline 12 & 1.23 & $6.05 \times 10^{-6}$ \\
\hline 16 & 1.107 & $6.82 \times 10^{-6}$ \\
\hline 21 & 0.987 & $7.86 \times 10^{-6}$ \\
\hline
\end{tabular}

Table 6.7: Measured Particle Density in 2 Lower Martin Lake cores collected by Mike Palmer, used to calculate average particle density used in the Porosity coefficient calculation. Average of both cores calculated to be $0.01 \mathrm{~g} / \mathrm{cm}^{3}$.

\begin{tabular}{|l|c|c|}
\hline \multicolumn{1}{|c|}{$\begin{array}{c}\text { Depth of Sediment Core } \\
(\mathbf{c m})\end{array}$} & $\begin{array}{c}\text { Particle Density of Core 1 } \\
\left(\mathbf{g} / \mathbf{c m}^{\mathbf{3}}\right)\end{array}$ & $\begin{array}{c}\text { Particle Density of Core 2 } \\
\left(\mathbf{g} / \mathbf{c m}^{\mathbf{3}}\right)\end{array}$ \\
\hline 0 & 0.012173 & 0.005593 \\
0.5 & 0.007896 & 0.008883 \\
1 & 0.010857 & 0.006909 \\
1.5 & 0.007896 & 0.010857 \\
2 & 0.013489 & 0.017108 \\
2.5 & 0.013160 & 0.011186 \\
\hline Average & 0.010912 & 0.010089 \\
\hline
\end{tabular}




\title{
C. R code for Calculating Predicted Sediment Fluxes of As from Lower
}

\author{
Martin Lake
}

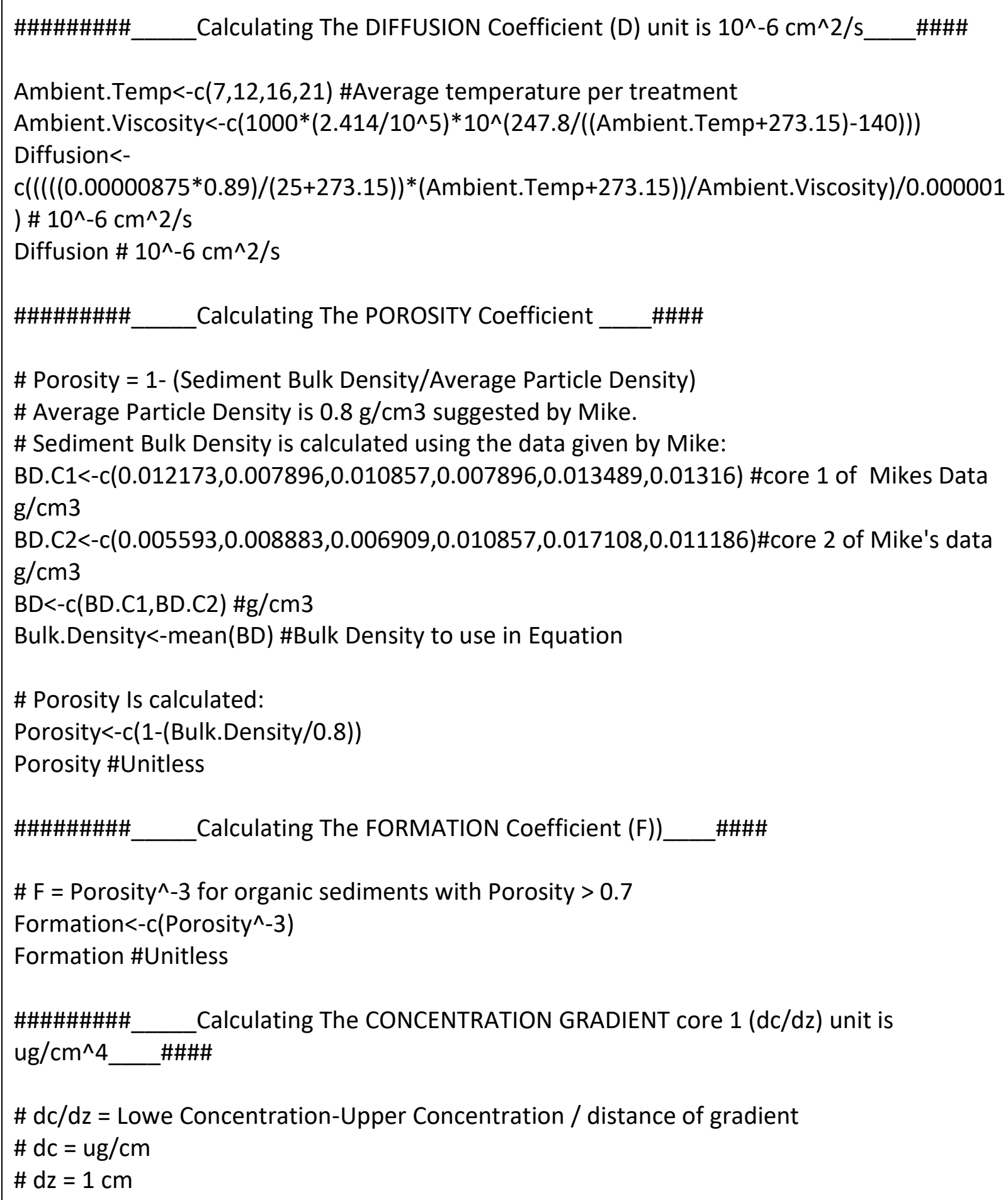




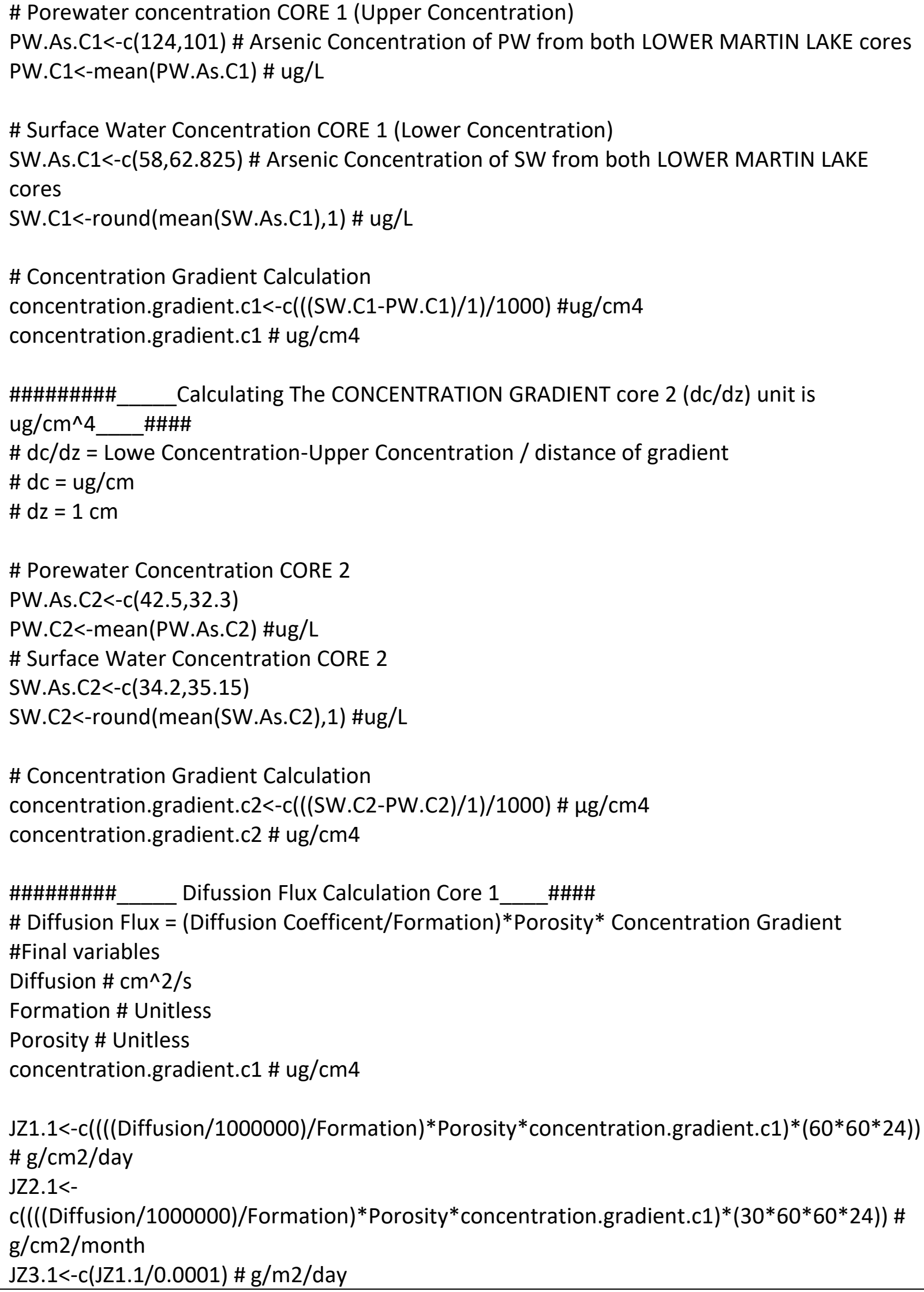




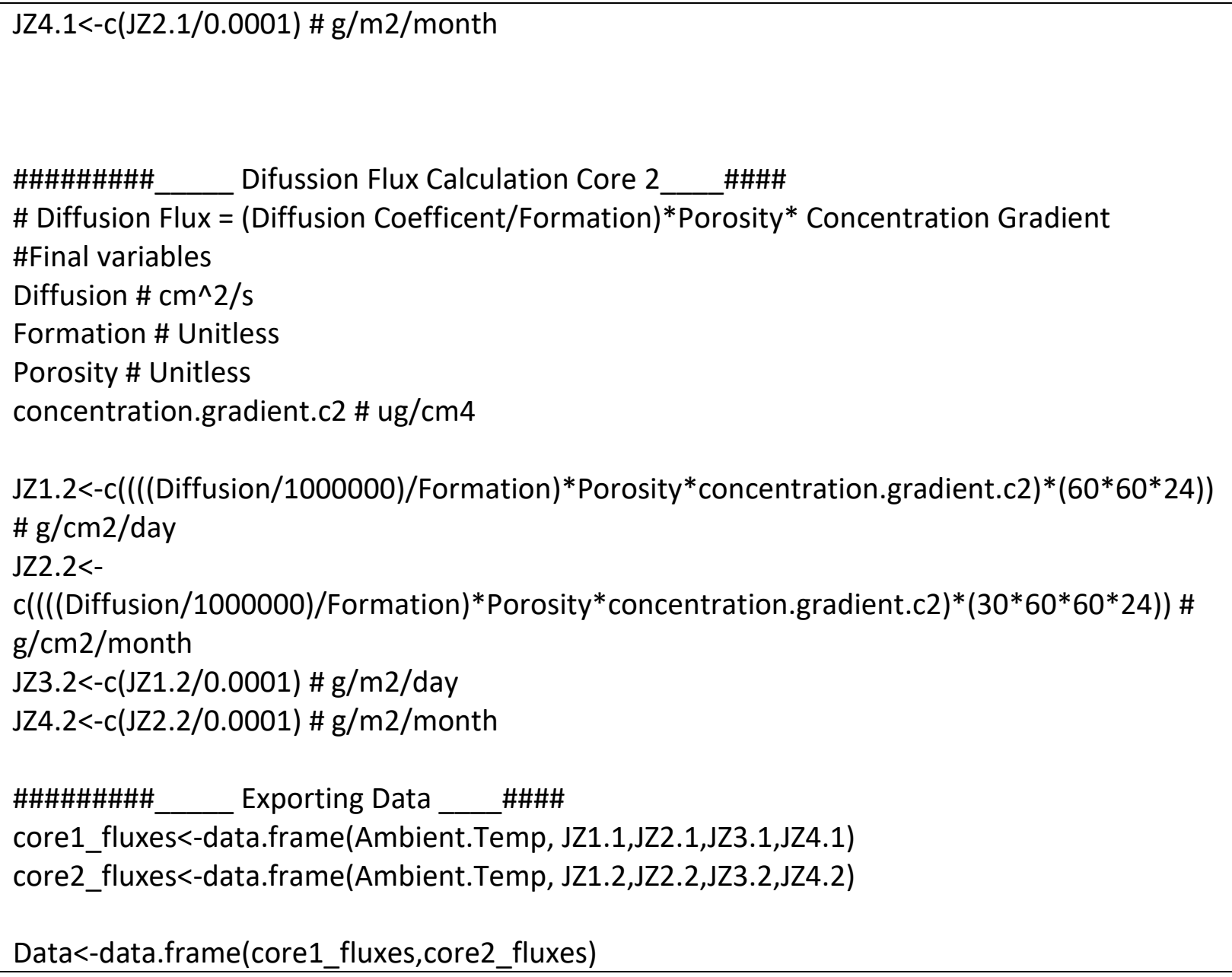


